
MONITORING PLAN

\title{
for the Area 3 and Area 5 \\ Radioactive Waste Management Sites at the \\ Nevada Test Site
}

U.S. Department of Energy National Nuclear Security Administration Nevada Site Office under Contract Number DE-AC08-96NV11718

June 2005 


\section{DISCLAIMER NOTICE}

This report was prepared as an account of work sponsored by an agency of the U.S. Government. Neither the U.S. Government nor any agency thereof, nor any of their employees, nor any of their contractors, subcontractors or their employees, makes any warranty or representation, express or implied, or assumes any legal liability or responsibility for the accuracy, completeness, or usefulness of any information, apparatus, product, or process disclosed, or represents that its use would not infringe privately own rights. Reference herein to any specific commercial product, process, or service by trade name, trademark, manufacturer, or otherwise, does not necessarily constitute or imply its endorsement, recommendation, or favoring by the U.S. Government or any agency thereof. The views and opinions of authors expressed herein do not necessarily state or reflect those of the U.S. Government or any agency thereof.

Available for sale to the public, in paper, from:

U.S. Department of Commerce

National Technical Information Service

5285 Port Royal Road

Springfield, VA 22161

Phone: (800) 553-6847

Fax: (703) 605-6900

E-mail: orders@ntis.fedworld.gov

Online Ordering: http://www.ntis.gov/ordering.htm

Available electronically at http://www.osti.gov/bridge

Available for a processing fee to the U.S. Department of Energy and its

contractors, in paper, from:

U.S. Department of Energy

Office of Scientific and Technical Information

P.O. Box 62

Oak Ridge, TN 37831-0062

Phone: (865) 576-8401

Fax: (865) 576-5728

E-mail: reports@adonis.osti.gov 


\section{INTEGRATED CLOSURE AND MONITORING PLAN for the Area 3 and Area 5 Radioactive Waste Management Sites at the Nevada Test Site}

Prepared for

U.S. Department of Energy

National Nuclear Security Administration

Nevada Site Office under Contract Number

DE-AC08-96NV11718

June 2005 
This Page Intentionally Left Blank 


\section{CONTENTS}

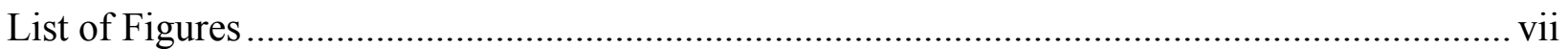

List of Tables vii

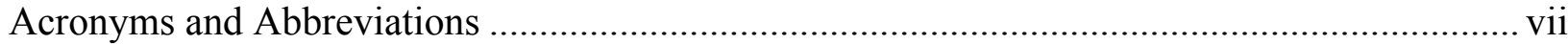

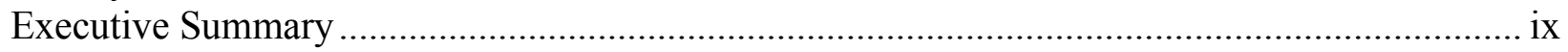

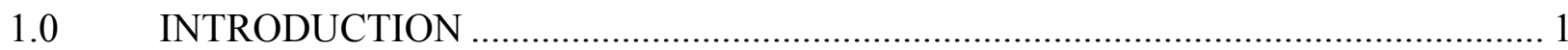

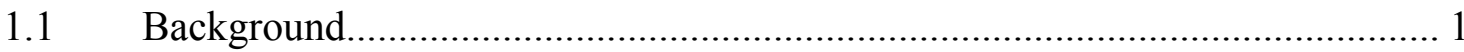

1.2 Objectives ........................................................................................... 2

1.3 Radioactive Waste Management Sites ........................................................ 2

1.3.1 Area 3 Radioactive Waste Management Site ................................. 2

1.3.2 Area 5 Radioactive Waste Management Site ................................ 2

1.4 Approaches to Closure and Monitoring .................................................... 6

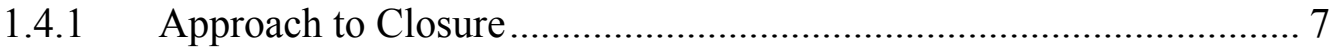

1.4.2 Approach to Monitoring ........................................................ 9

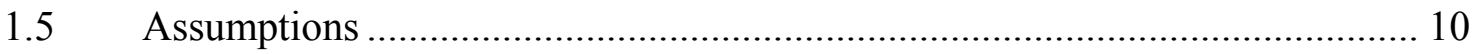

1.5.1 Assumptions Related to Closure.................................................... 10

1.5.2 Assumptions Related to Monitoring.............................................. 11

1.5.3 Assumptions Related to Long-Term Surveillance and Maintenance.............................................................................. 11

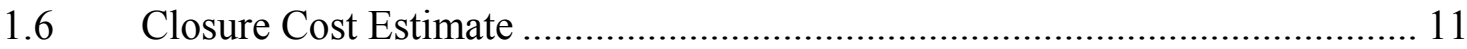

1.7 Monitoring Cost Estimate....................................................................... 12

$1.8 \quad$ Closure and Monitoring Schedule ........................................................... 12

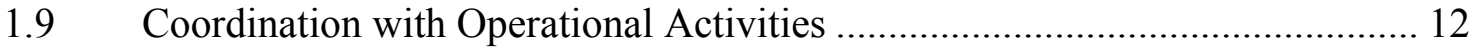

1.10 Closure and Monitoring Plan Maintenance and Amendment ......................... 13

2.0 WORK SMART STANDARDS AND COMPLIANCE STRATEGY ..................... 15

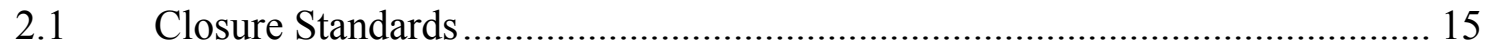

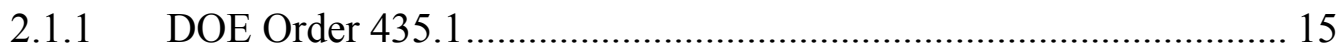

2.1.2 Title 40 CFR 265 ................................................................... 16

2.1.3 Title 40 CFR 191 ...................................................................... 17

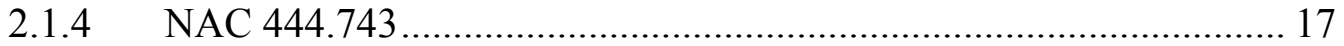




\section{CONTENTS}

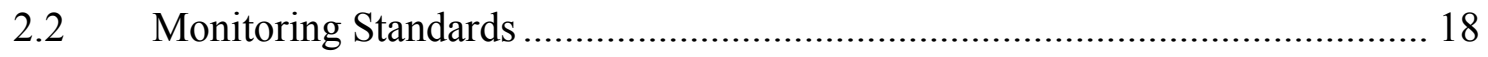

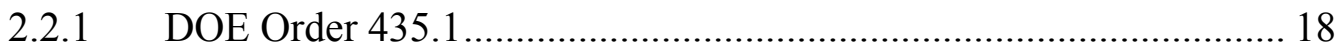

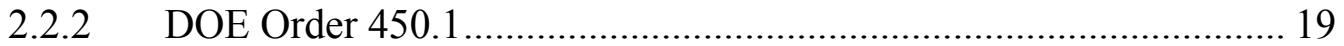

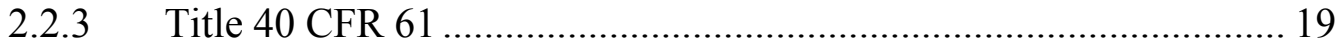

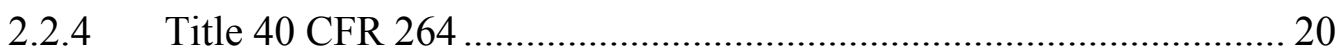

2.2.5 Title 40 CFR 265 ................................................................... 20

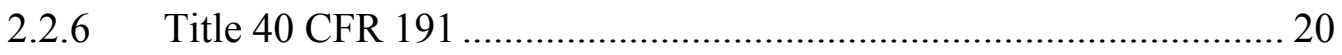

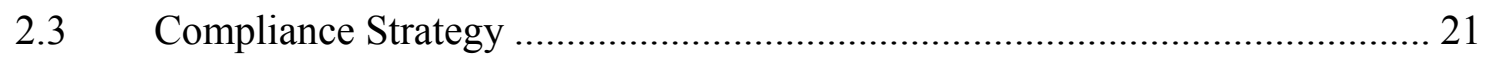

SITE CHARACTERISTICS ........................................................................ 23

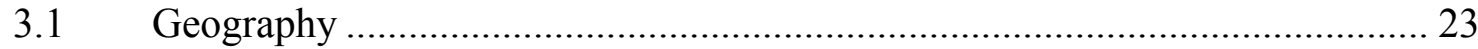

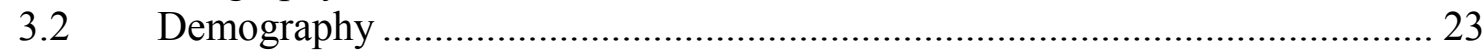

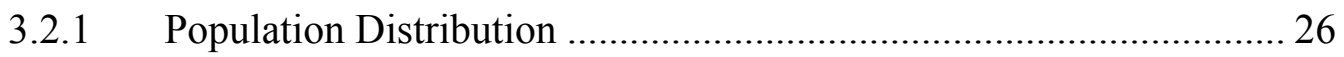

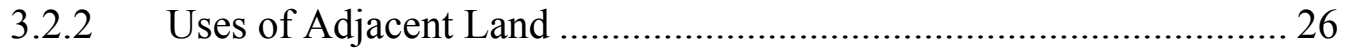

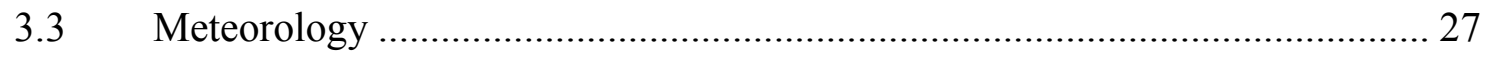

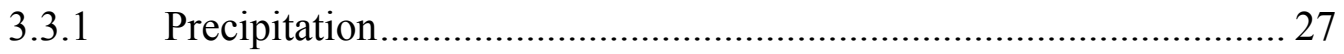

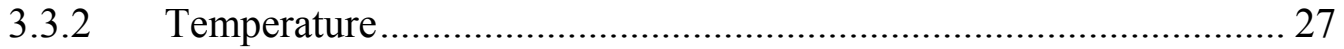

3.3.3 Potential Evapotranspiration........................................................ 28

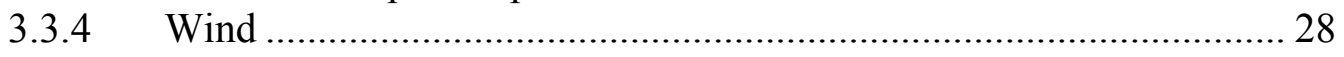

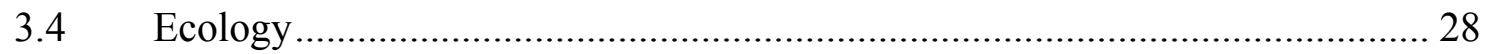

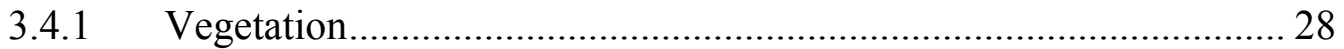

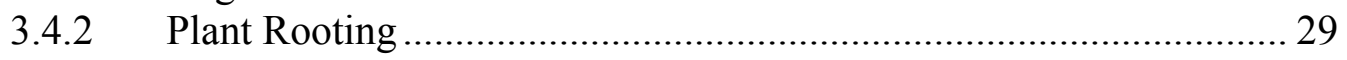

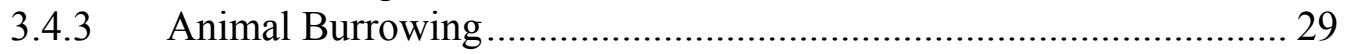

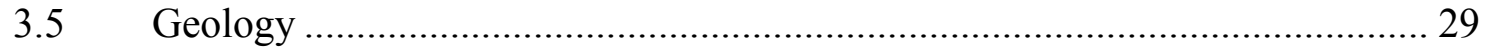

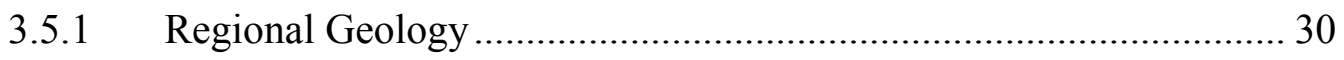

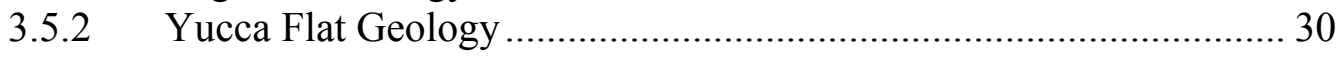

3.5.3 Frenchman Flat Geology ........................................................ 31 


\section{CONTENTS}

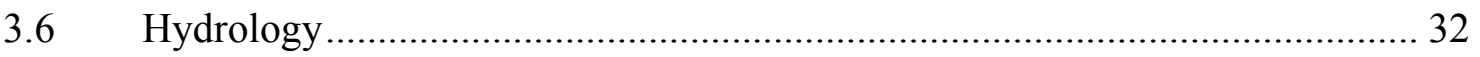

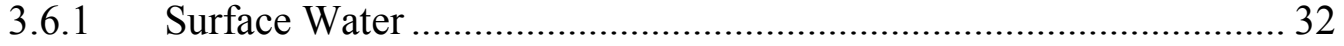

3.6.2 Unsaturated Zone....................................................................... 32

3.6.3 Saturated Zone ......................................................................... 34

3.6.4 Groundwater Chemistry ....................................................... 37

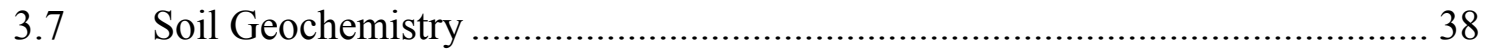

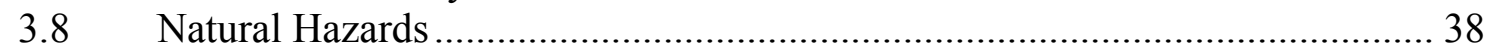

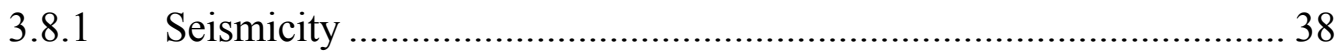

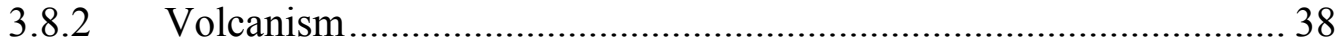

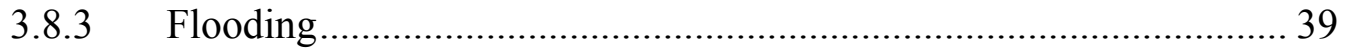

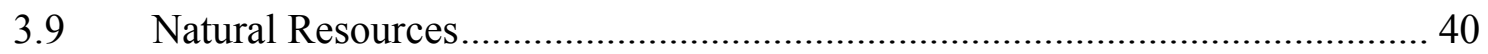

4.0 AREA 3 RADIOACTIVE WASTE MANAGEMENT SITE

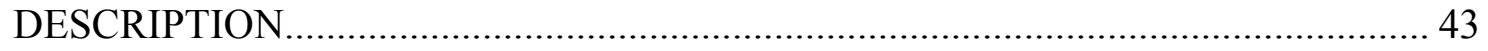

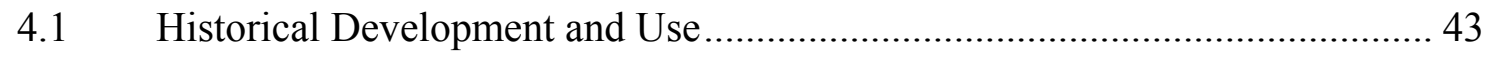

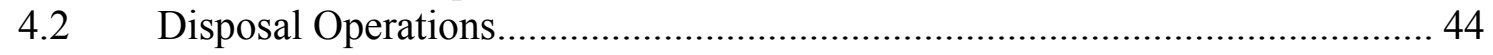

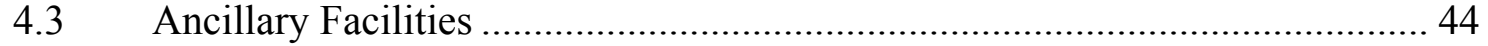

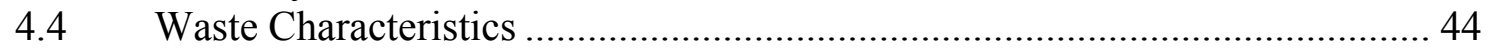

4.4.1 Waste Containers ...................................................................... 44

4.4.2 Treatment or Processing Prior to Disposal ...................................... 44

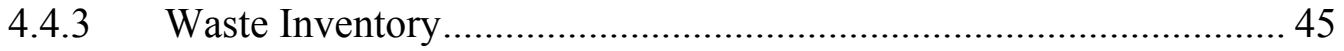

4.5 Performance Assessment and Composite Analysis...................................... 45

4.5.1 Performance Objectives........................................................ 45

4.5.3 Maintenance Program................................................................. 49

5.0 AREA 5 RADIOACTIVE WASTE MANAGEMENT SITE DESCRIPTION ............ 51

5.1 Historical Development and Use.......................................................... 51

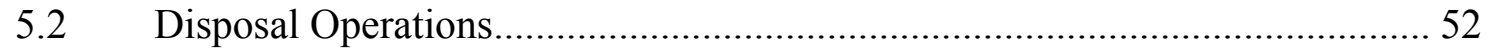

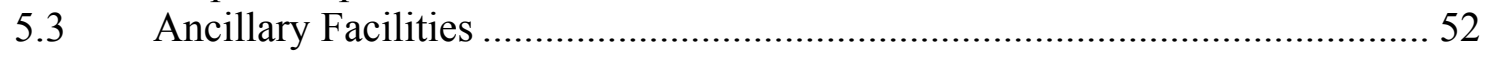

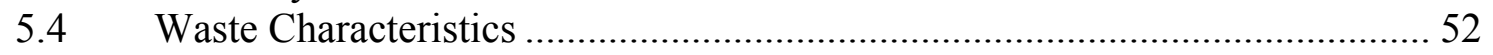

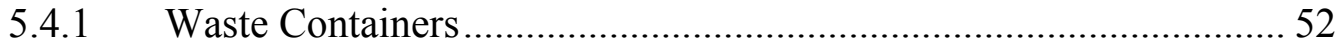

5.4.2 Treatment or Processing Prior to Disposal ....................................... 53

5.4.3 Waste Inventory................................................................. 53 


\section{CONTENTS}

5.5 Performance Assessment and Composite Analysis.................................... 53

5.5.1 Performance Objectives............................................................ 53

5.5.2 Status of Performance Assessment and Composite Analysis............ 53

5.5.3 Maintenance Program.................................................................... 55

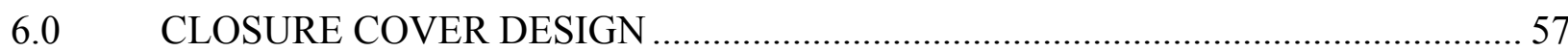

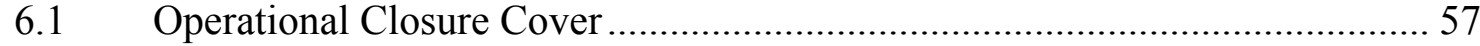

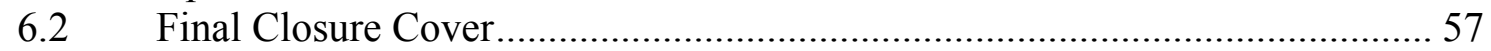

6.2.1 Cover Composition.................................................................. 58

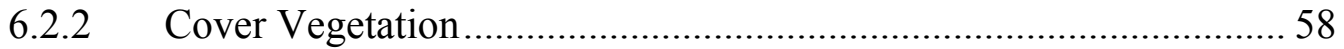

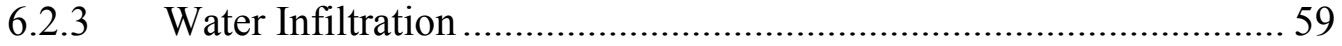

6.2.4 Plant Rooting and Animal Burrowing ........................................ 59

6.2.5 Inadvertent Intruder Barrier........................................................ 59

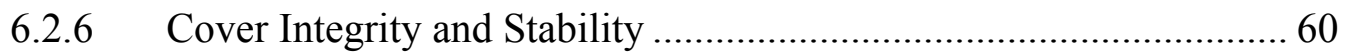

6.2.7 Cover Configuration, Site Grading, and Drainage ...........................6 60

6.2.8 Cover Security, Markers, and Protection........................................ 61

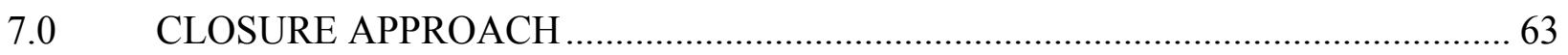

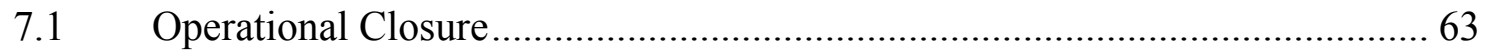

7.1.1 Area 3 Radioactive Waste Management Site ................................. 63

7.1.2 Area 5 Radioactive Waste Management Site ................................. 64

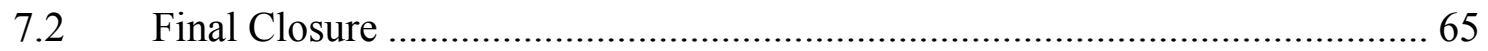

7.2.1 Area 3 Radioactive Waste Management Site ................................ 65

7.2.2 Area 5 Radioactive Waste Management Site .................................. 65

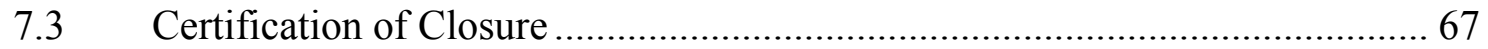

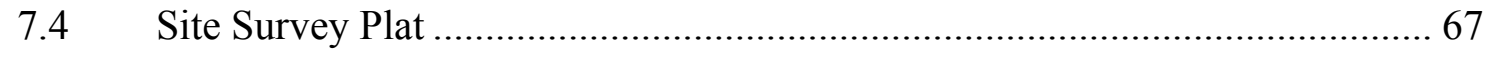

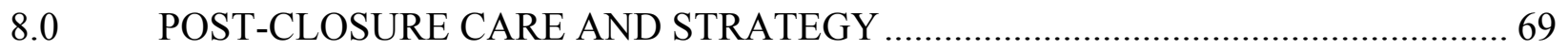

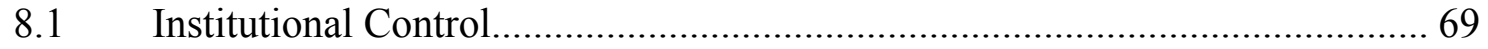

8.1.1 Active Institutional Control ................................................... 70

8.1.2 Passive Institutional Control..................................................... 71

8.1.3 Unrestricted Release of Sites ....................................................... 71 


\section{CONTENTS}

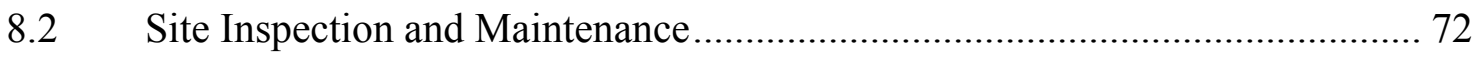

$8.3 \quad$ Protection from Adverse Impact .............................................................. 74

8.3.1 Groundwater .............................................................................. 74

8.3.2 Human Health and Environment ..................................................... 75

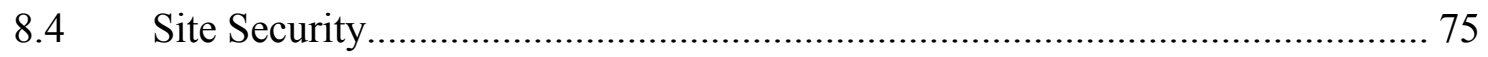

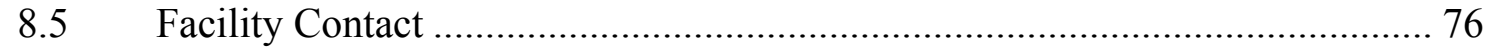

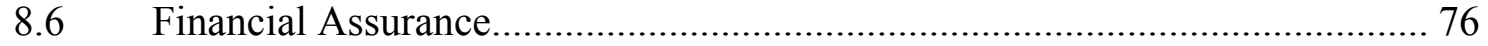

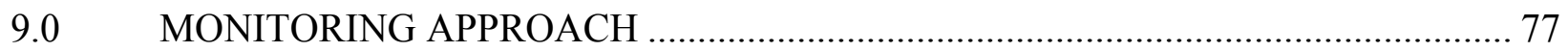

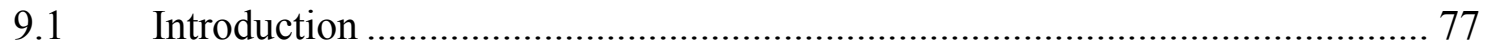

9.2 Quality Assurance, Analysis, and Sampling Plans.......................................... 78

9.3 Routine Radiological Environmental Monitoring Plan .................................... 78

9.4 Operational Closure and Post-Closure Monitoring …….................................. 80

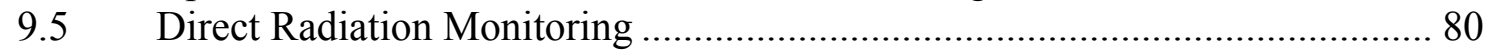

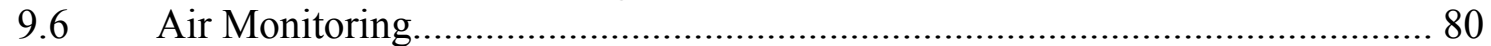

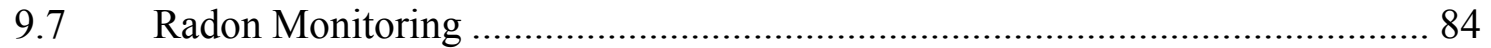

$9.8 \quad$ Vadose Zone Monitoring ................................................................................. 85

9.8.1 Area 3 Drainage Lysimeter Facility ……………………………..... 86

9.8.2 Area 5 Weighing Lysimeter Facility ................................................. 86

9.8.3 Automated Vadose Zone Monitoring Systems................................... 87

9.8.4 Neutron Logging ……………………………................................ 88

9.8.5 Soil-gas Monitoring for Tritium ....................................................... 89

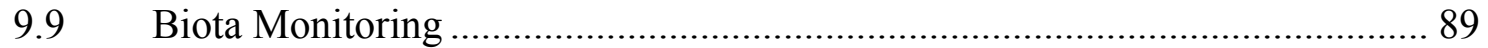

9.10 Surface Water Runoff Monitoring.............................................................. 90

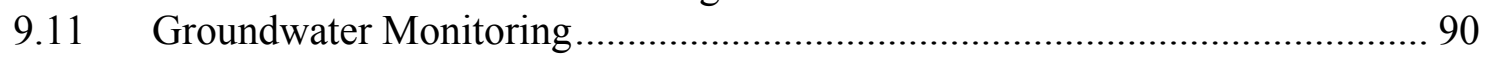

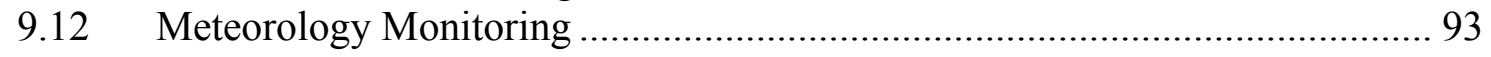

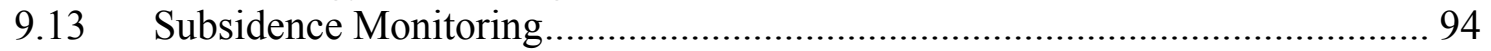

9.14 Monitoring During Active Institutional Control ………................................. 94

9.15 Monitoring During Passive Institutional Control ............................................. 95

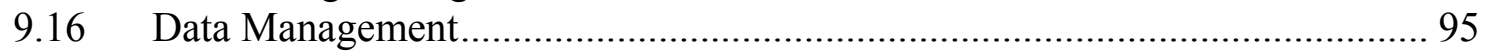

9.17 Data Evaluation and Data Reporting ........................................................... 95

9.18 Organizational Instructions ………………….......................................... 96

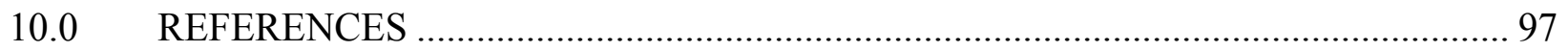

Appendix A Cross-Walk Between Closure Plan Guidance and the Integrated Closure And Monitoring Plan 


\section{List of Figures}

Figure 1.1 Locations of the Area 3 and Area 5 Radioactive Waste Management Sites, Nevada Test Site 97

Figure 1.2 Layout of the Area 3 Radioactive Waste Management Site showing the disposal units and waste types ........................................................................ 4

Figure 1.3 Layout of the Area 5 Radioactive Waste Management Site showing disposal units and waste types... 97

Figure 1.4 Locations of the Greater Confinement Disposal boreholes at the Area 5 Radioactive Waste Management Site 97

Figure 3.1 General geologic map of Yucca Flat and vicinity ………..................................... 97

Figure 3.2 General geologic map of Frenchman Flat and vicinity …………......................... 97

Figure 3.3 Conceptual model of near-surface processes in the unsaturated zone. 97

Figure 3.4 Conceptual model of water-flow regions in the unsaturated zone in the vicinity of the Area 5 Radioactive Waste Management Site............................ 97

Figure 6.1 Conceptual model of an evapotranspiration closure cover over waste in shallow land burial ......................................................................................... 97

Figure 9.1 Locations and types of monitoring wells at the Area 3 Radioactive Waste Management Site 97

Figure 9.2 Locations of "pilot" monitoring wells, lysimeter facility, and the flume at the Area 5 Radioactive Waste Management Site 97

Figure 9.3 Locations and types of monitoring stations at the Area 5 Radioactive Waste Management Site 97

Figure 9.4 Locations of flume at the Area 3 Radioactive Waste Management Site 97

\section{List of Tables}

Table 1.1 Schedule of the ten-step approach for closure of the Area 5 RWMS

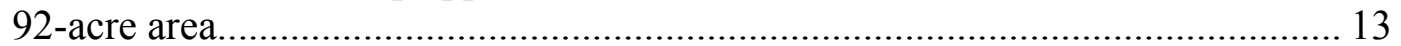

Table 4.1 Area 3 RWMS PA Estimated Inventory............................................................ 46

Table 4.2 Performance objectives and results of the Area 3 and Area 5 RWMS Performance Assessments ............................................................................... 48

Table 5.1 Area 5 RWMS PA Estimated Inventory............................................................... 54

Table 7.1 Categories of disposal units at the Area 3 RWMSs based on security requirements, waste type, and disposal configuration. 66

Table 9.1 Monitoring activities at the Area 3 and Area 5 Radioactive Waste Management Sites 79 


\section{ACRONYMS and ABBREVIATIONS}

\begin{tabular}{|c|c|}
\hline AA & alluvial aquifer \\
\hline $\mathrm{AC}$ & acres \\
\hline ASER & Annual Site Environmental Report \\
\hline BEIDMS & Bechtel Environmental Integrated Data Management System \\
\hline $\mathrm{Bq} / 1$ & Becquerel/liter \\
\hline $\mathrm{Bq} / \mathrm{m} 2 / \mathrm{s}$ & Becquerel/square meter/second \\
\hline $\mathrm{BN}$ & Bechtel Nevada \\
\hline $\mathrm{C}$ & Celsius \\
\hline CA & Composite Analysis \\
\hline CADD & Corrective Action Decision Document \\
\hline CAU & Corrective Action Unit \\
\hline CFR & Code of Federal Regulations \\
\hline $\mathrm{CM}$ & centimeters \\
\hline DAS & Disposal Authorization Statement \\
\hline $\mathrm{DOE} / \mathrm{HQ}$ & U.S. Department of Energy/Headquarters \\
\hline $\mathrm{DOE} / \mathrm{NV}$ & U.S. Department of Energy/Nevada Operations Office \\
\hline DQO & Data Quality Objectives \\
\hline DVRFS & Death Valley Regional Flow System \\
\hline EPA & U.S. Environmental Protection Agency \\
\hline ET & evapotranspiration \\
\hline ETS & Environmental Technical Services (BN) \\
\hline $\mathrm{F}$ & Fahrenheit \\
\hline FFACO & Federal Facilities Agreement and Consent Order \\
\hline FT & feet \\
\hline FY & fiscal year \\
\hline $\mathrm{G}$ & gallons \\
\hline GCD & Greater Confinement Disposal \\
\hline HA & hectares \\
\hline HD & heat dissipation (probe) \\
\hline HSA & High Specific Activity \\
\hline HWSU & Hazardous Waste Storage Unit \\
\hline ICMP & Integrated Closure and Monitoring Plan \\
\hline IHI & Inadvertent Human Intrusion \\
\hline IN & inches \\
\hline $\mathrm{K}$ & kilometers \\
\hline $\mathrm{L}$ & liters \\
\hline LCA & Lower Carbonate Aquifer \\
\hline LCCU & Lower Clastic Confining Unit \\
\hline LLW & low-level waste \\
\hline LTCU & Lower Tuff Confining Unit \\
\hline LTSM & long-term surveillance and maintenance \\
\hline M & meters \\
\hline MI & miles \\
\hline MLLW & mixed low-level waste \\
\hline
\end{tabular}




\begin{tabular}{|c|c|}
\hline mrem & millirem \\
\hline $\mathrm{mSv}$ & milliSievert \\
\hline MTRU & mixed transuranic (waste) \\
\hline MWDU & Mixed Waste Disposal Unit \\
\hline NAC & Nevada Administrative Code \\
\hline NDEP & Nevada Division of Environmental Protection \\
\hline NESHAP & National Emissions Standard for Hazardous Air Pollutants \\
\hline NNSA/NSO & National Nuclear Security Administration Nevada Site Office \\
\hline NTS & Nevada Test Site \\
\hline NTSER & Nevada Test Site Environmental Report \\
\hline OI & Operating Instruction \\
\hline OP & Organization Procedure \\
\hline PA & Performance Assessment \\
\hline $\mathrm{pCi} / \mathrm{m} 2$ & picoCuries/square meter \\
\hline PET & potential evapotranspiration \\
\hline QAASP & Quality Assurance, Analysis, and Sampling Plan \\
\hline RCRA & Resource Conservation and Recovery Act \\
\hline RREMP & Routine Radiological Environmental Monitoring Plan \\
\hline RWMS & Radioactive Waste Management Site \\
\hline SME & Subject Matter Expert \\
\hline SNL & Sandia National Laboratories \\
\hline SWL & static water level \\
\hline TCU & Tuff Confining Unit \\
\hline TDR & Time-Domain Reflectometry \\
\hline TLD & Thermoluminescent Dosimeter \\
\hline TMA & Timber Mountain Aquifer \\
\hline TM-WTA & Timber Mountain Welded Tuff Aquifers \\
\hline TRU & transuranic \\
\hline TSA & Tonopah Spring Aquifers \\
\hline UGTA & Underground Test Area \\
\hline VCU & Volcaniclastic Confining Unit \\
\hline WAC & Waste Acceptance Criteria \\
\hline WEF & Waste Examination Facility \\
\hline WIPP & Waste Isolation Pilot Plant \\
\hline WMD & Waste Management Division (NNSA/NSO) \\
\hline YR & year \\
\hline
\end{tabular}




\section{EXECUTIVE SUMMARY}

This document is an integrated plan for closing and monitoring two low-level radioactive waste disposal sites at the Nevada Test Site (NTS). The Area 3 and Area 5 Radioactive Waste Management Sites (RWMSs) are managed and operated by Bechtel Nevada for the U.S. Department of Energy's (DOE's) National Nuclear Security Administration Nevada Site Office (NNSA/NSO). This Integrated Closure and Monitoring Plan (ICMP) identifies the assumptions and regulatory requirements, describes the disposal sites and the physical environment in which they are located, describes the design of the closure cover, and defines the approach and schedule for both closing and monitoring the sites. The plan serves as a reference document for specific closure plans.

The ICMP for these sites is based on guidance for developing closure plans issued by the DOE (DOE, 1999a). Closure and monitoring were integrated because monitoring measures the degree to which the operational and closed disposal facilities are meeting performance objectives specified in the manual to DOE Order 435.1 (DOE O 435.1). Department of Energy O 435.1 governs management of radioactive waste, and associated with it are Manual DOE M 435.1-1 and Guidance DOE G 435.1-1. The performance objectives are intended to ensure protection of workers, the public, and the environment from radiological exposure associated with the RWMSs now and in the future. This 2005 version of the ICMP will be published as Revision 2.

The Area 3 and Area 5 RWMSs accept low-level waste (LLW) from across the DOE Complex according to the NTS Waste Acceptance Criteria (NNSA/NSO, 2003). The Area 3 RWMS accepts both packaged and unpackaged bulk LLW for disposal in craters that resulted from underground testing of nuclear devices in the 1960s. The Area 5 RWMS accepts primarily packaged LLW for disposal in excavated pits and trenches.

The Area 3 RWMS covers 48 hectares (ha) (120 acres [ac]) and is comprised of seven subsidence craters - U-3ax, U-3bl, U-3ah, U-3at, U-3bh, U-3az, and U-3bg. The area between craters U-3ax and U-3bl was excavated to form one large disposal unit (U-3ax/bl); the area between craters U-3ah and U-3at was also excavated to form another large disposal unit (U-3ah/at). Waste unit U-3ax/bl is closed; waste units U-3ah/at and U-3bh are active; and the remaining craters, although currently undeveloped, are available for disposal of waste if required.

The Area 5 RWMS covers 293 ha (732 ac) and is bounded by a buffer zone 300 meters (1,000 feet) wide. The southeast and northeast quadrants of the RWMS are actively used for disposal or storage of wastes, although many of the disposal units in the southeast quadrant are operationally closed or nearing capacity. The southeast quadrant covers 37 ha (92 ac), and is referred to as the "92-ac area." The northeast quadrant is being developed and is referred to as the "expansion area."

Most waste disposal units at both the Area 3 and Area 5 RWMSs are expected to be closed over the next several decades. Closure of the RWMSs will proceed through three phases: operational closure, final closure, and institutional control. Many waste disposal units at the Area 5 RWMS are operationally closed and a final closure cover has been placed on unit U-3ax/bl (Corrective Action Unit 110) at the Area 3 RWMS. 
A monolayer-evapotranspiration (ET) closure cover was selected as the preferred alternative design to a multilayered Resource Conservation and Recovery Act (RCRA) closure cover and other alternative designs only after a comprehensive evaluation of many alternatives. The operational and final closure covers will be constructed of locally derived native soil. Multiple lines of evidence suggest that a monolayer-ET design will cost considerably less than a multilayer RCRA design, be much easier to install and maintain and, in an arid environment, perform according to performance criteria over long periods of time, even under conditions of cover subsidence. The monolayer-ET cover and natural conditions at the NTS will integrate and operate as a system. Natural conditions that optimize the system are: extremely low precipitation and high potential ET, large depth to groundwater, and negligible recharge to groundwater.

Activities associated with final closure of the Area 5 RWMS 92-ac area are scheduled to start in fiscal year (FY) 2005 and be completed in FY 2010. Activities associated with final closure of the Area 5 expansion area north of the 92-ac site are scheduled to start in FY 2019 and be completed in FY 2021. In FY 2004, a Six Sigma Process Improvement Project was conducted that may lead to a decision to close the Area 3 RWMS within the next few years. Should this decision be made, activities leading to final closure of the Area 3 RWMS could start as early as FY 2006, with final closure as early as FY 2008.

Monitoring at the Area 3 and Area 5 RWMSs is required under a variety of regulatory drivers, including federal regulations and DOE Orders. Monitoring data, collected via sensors and analysis of samples, are needed to evaluate radiation doses to the general public; for performance assessment performance confirmation, validation, and maintenance; to demonstrate regulatory compliance; and to evaluate the actual performance of the RWMSs. Monitoring provides data to ensure the integrity and performance of waste disposal units. The monitoring program is designed to forewarn management and regulators of any failure and need for mitigating actions.

The ICMP describes the program for monitoring direct radiation, air, vadose zone, biota, groundwater, meteorology, and subsidence at the Area 3 and Area 5 RWMSs during the operational closure period (current), final closure, and active institutional control periods.

Active institutional controls, such as control of access, cover maintenance, and monitoring, will start after final closure and continue for 100 years. For wastes with hazardous constituents, institutional controls will be conducted according to the RCRA permit conditions negotiated with the Nevada Division of Environmental Protection. Passive institutional controls, such as markers, records, or archives, and government ownership regulations regarding land and resource use, will continue thereafter. Management of the RWMSs in both Area 3 and Area 5 is planned to eventually be transferred to another agency or group within NNSA/NSO that is expected to have long-term responsibilities at the NTS. Under this NTS Landlord, waste disposal operations may continue in selected disposal units. The Landlord will also oversee and conduct institutional control activities. 


\subsection{INTRODUCTION}

This document is an integrated plan for closing and monitoring two low-level radioactive waste disposal sites at the Nevada Test Site (NTS). The Area 3 and Area 5 Radioactive Waste Management Sites (RWMSs) are managed and operated by Bechtel Nevada (BN) for the U.S. Department of Energy's (DOE's) National Nuclear Security Administration Nevada Site Office (NNSA/NSO). The Integrated Closure and Monitoring Plan (ICMP) for these sites is based on guidance for developing closure plans issued by the DOE (DOE, 1999a). The plan does not closely follow the format suggested by the DOE guidance to better accommodate differences between the two RWMSs, especially in terms of operations and site characteristics. The modification reduces redundancy and provides a smoother progression of the discussion. Further, much of the information that would be included in the individual plans is the same, and integration provides efficient presentation. A cross-walk between the contents of the ICMP and the DOE guidance is given in Appendix A.

Closure and monitoring were integrated because monitoring measures the degree to which the operational and closed disposal facilities are meeting performance objectives specified in the manual to DOE Order O 435.1. Department of Energy Order 435.1 governs management of radioactive waste, and associated with it are Manual DOE M 435.1-1 and Guidance DOE G 435.1-1. The performance objectives are intended to ensure protection of workers, the public, and the environment from radiological exposure associated with the RWMSs now and in the future.

\subsection{Background}

Manual DOE M 435.1-1 specifies that preliminary closure and monitoring plans for a low-level waste (LLW) management facility be developed and initially submitted with the Performance Assessment (PA) and Composite Analysis (CA) for that facility. These plans are then to be updated within one year following issuance of the facility's Disposal Authorization Statement (DAS) to incorporate conditions specified in the DAS. The PA for the Area 5 RWMS was reviewed and approved with conditions by DOE Headquarters (HQ) in 1996 and a DAS was issued in December 2000, after review of the draft CA (the final CA for the Area 5 RWMS was published in September 2001). The combined PA and CA for the Area 3 RWMS was reviewed by DOE/HQ in 1999 and a conditional DAS was issued in October 1999.

Preliminary closure and monitoring plans were not submitted with either the Area 3 or Area 5 RWMS PAs and CAs. Rather, issuance of the DAS for the Area 3 RWMS started development of closure and monitoring plans for the Area 3 RWMS. The ICMP was written for both the Area 3 and Area 5 RWMSs and an initial version was published in October 2000, within the oneyear period specified in the Area 3 RWMS DAS. Significant changes in the conceptual approach to closure of the Area 5 RWMS occurred soon after publication of the initial version of the ICMP, prompting rewriting of the document. The subsequent version of the ICMP was published in September 2001 without indication of it being a revision; that is, the initial version was abandoned. However, this 2005 version of the ICMP is published as Revision 2. 


\subsection{Objectives}

Over the next several decades, most waste disposal units at both the Area 3 and Area 5 RWMSs are expected to be closed. This ICMP identifies the assumptions and regulatory requirements, describes the disposal sites and the physical environment in which they are located, describes the design of the closure cover, and defines the approach and schedule for both closing and monitoring the sites. The plan will serve as a reference document for specific closure plans.

\subsection{Radioactive Waste Management Sites}

The Area 3 and Area 5 RWMSs accept LLW from across the DOE Complex according to the NTS Waste Acceptance Criteria (NTSWAC) (NNSA/NSO, 2003). The Area 3 RWMS accepts both packaged and unpackaged bulk LLW for disposal in craters that resulted from underground testing of nuclear devices in the 1960s. The Area 5 RWMS accepts primarily packaged LLW for disposal in excavated pits and trenches.

\subsubsection{Area 3 Radioactive Waste Management Site}

The Area 3 RWMS is approximately 45 kilometers $(\mathrm{km})$ (28 miles [mi]) northwest of Mercury, Nevada, in the east-central part of Yucca Flat, in the northeast part of the NTS (Figure 1.1). The Area 3 RWMS covers 48 hectares (ha) (120 acres [ac]) and is comprised of seven subsidence craters - U-3ax, U-3bl, U-3ah, U-3at, U-3bh, U-3az, and U-3bg (Figure 1.2). The area between craters U-3ax and U-3bl was excavated to form one large disposal unit (U-3ax/bl); the area between craters U-3ah and U-3at was also excavated to form another large disposal unit (U-3ah/at). Waste unit U-3ax/bl is closed; waste units U-3ah/at and U-3bh are active; and the remaining craters, although currently undeveloped, are available for disposal of waste if required. The RWMS boundary is marked by a wire fence. Access to the RWMS is through a gate on the north side of the facility, adjacent to structures that house office space and access control. The craters and infrastructure associated with disposal operations within the fence boundary have largely disturbed natural conditions. This is also true, but to a lesser extent, beyond the fence boundary. Infrastructure and controlled areas resulting from nearby aboveground nuclear tests are present around the RWMS.

\subsubsection{Area 5 Radioactive Waste Management Site}

The Area 5 RWMS is approximately $22 \mathrm{~km}$ (14 mi) north of Mercury, Nevada, in the northern part of Frenchman Flat (Figure 1.1). The Area 5 RWMS covers 293 ha (732 ac) and is bounded by a buffer zone 300 meters $(\mathrm{m})(1,000$ feet [ft]) wide. The southeast and northeast quadrants of the RWMS are actively used for disposal or storage of wastes, although many of the disposal units in the southeast quadrant are operationally closed or nearing capacity (Figure 1.3). The southeast quadrant covers $37 \mathrm{ha}(92 \mathrm{ac})$, and is referred to as the "92-ac area." The northeast quadrant is being developed and is referred to as the "expansion area." Packaged LLW, mixed low-level waste (MLLW) generated within Nevada under the purview of NNSA/NSO, and asbestiform waste are currently disposed in excavated disposal units which, with exceptions, are 


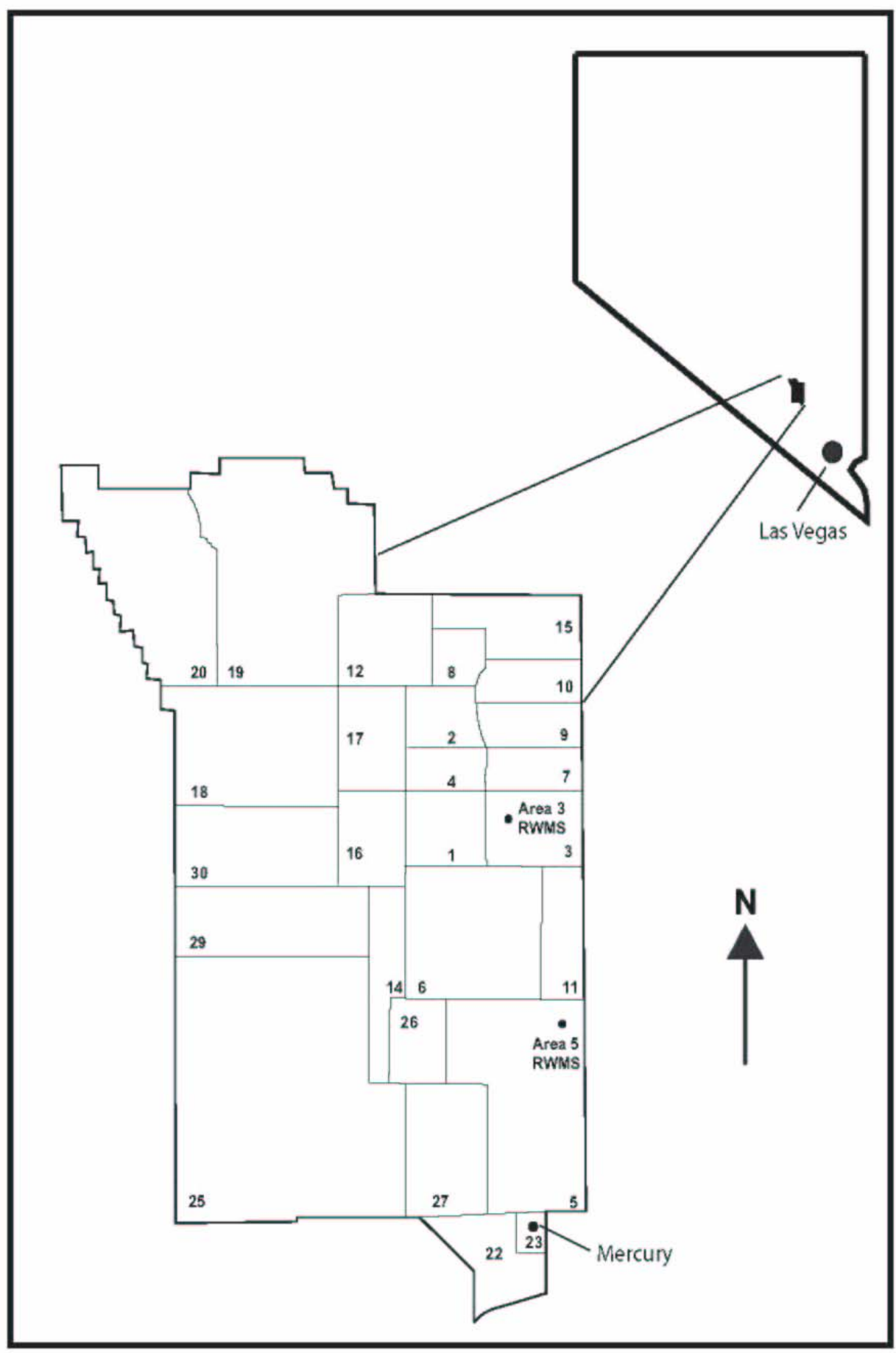

Figure 3.1 Locations of the Area 3 and Area 5 Radioactive Waste Management Sites, Nevada Test Site 


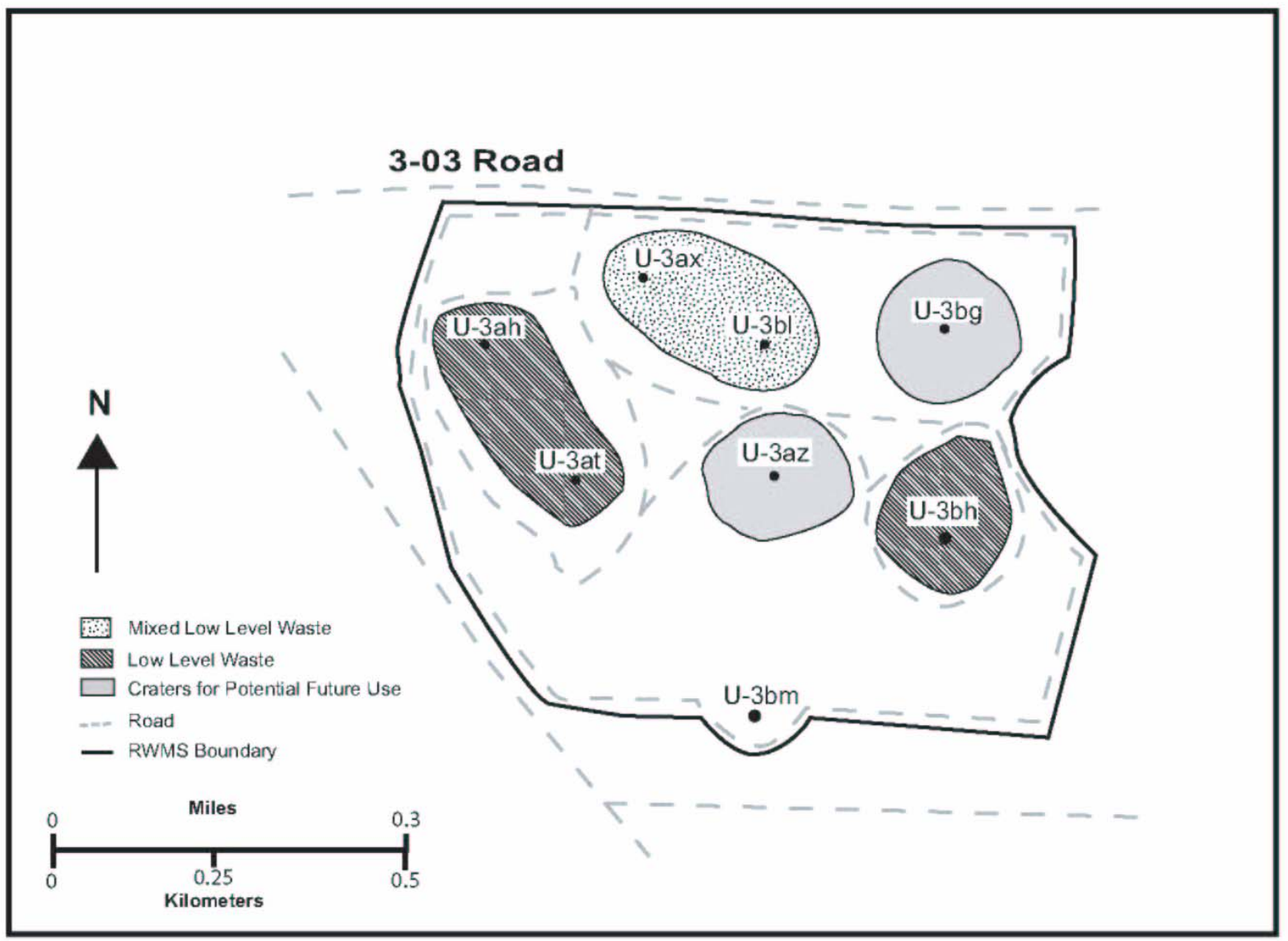

Figure 1.4 Layout of the Area 3 Radioactive Waste Management Site showing the disposal units and waste types 


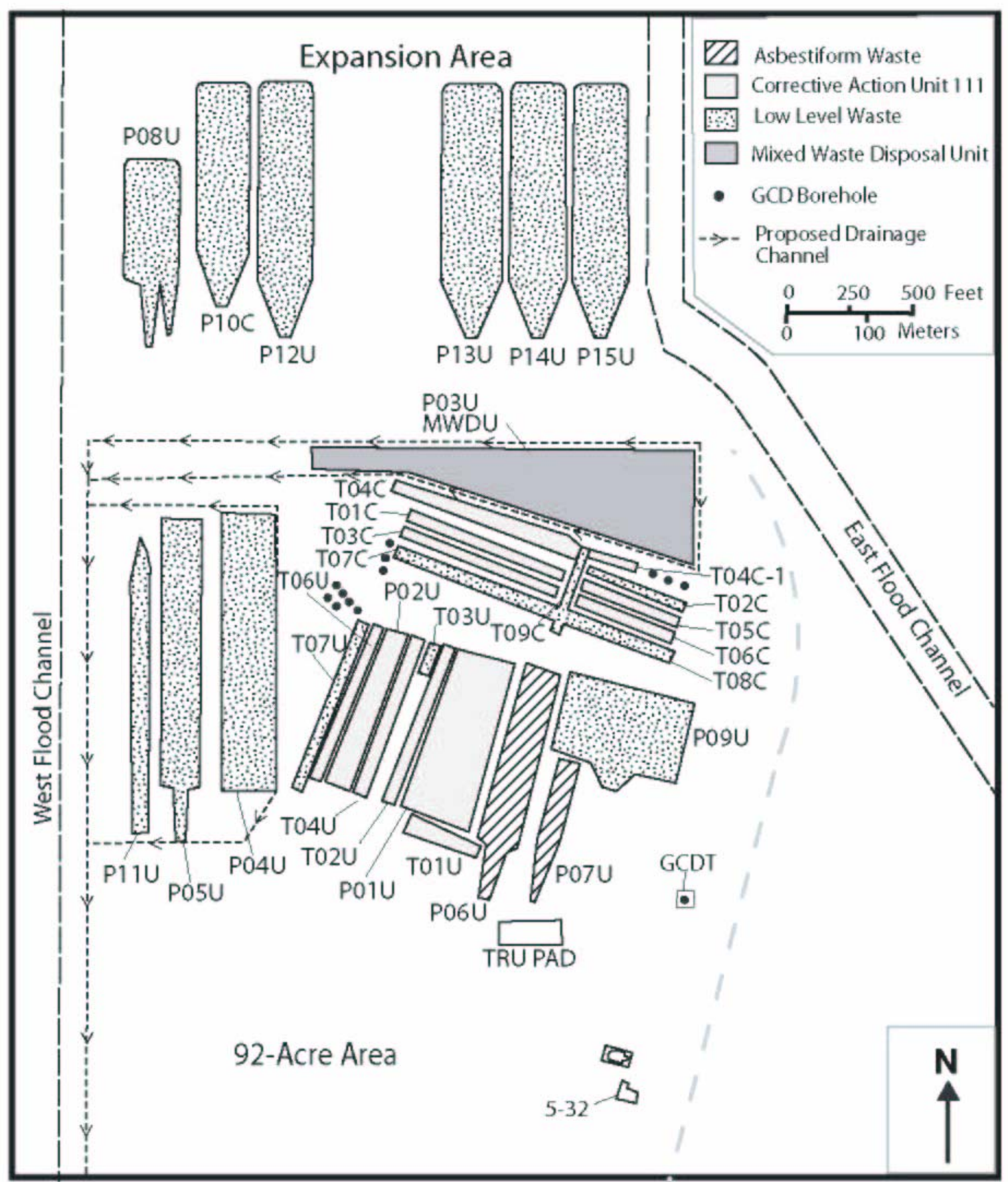

Figure 1.3 Layout of the Area 5 Radioactive Waste Management Site showing disposal units and waste types 
typically between 180 and $210 \mathrm{~m}$ (600 and $700 \mathrm{ft})$ long, 12 and $18 \mathrm{~m}(40$ and $60 \mathrm{ft})$ wide, and 6 and $9 \mathrm{~m} \mathrm{(20} \mathrm{and} 30 \mathrm{ft})$ deep. ${ }^{1}$ Four of 25 disposal units within the 92 -ac area are active. ${ }^{2}$ The other disposal units are operationally closed with a cover of native soil approximately $2.4 \mathrm{~m}$ $(8 \mathrm{ft})$ thick. Excess screened soil from excavation of new pits in the expansion area may be added to the operational closure covers to increase the thickness.

In addition to pits and trenches, 13 Greater Confinement Disposal (GCD) boreholes are present within the 92-ac area (Figure 1.4) These boreholes are typically $3 \mathrm{~m}(10 \mathrm{ft})$ in diameter and $36 \mathrm{~m}$ $(120 \mathrm{ft})$ deep and unlined except for the top $3 \mathrm{~m}(10 \mathrm{ft})$, which are cased with corrugated metal pipe. The GCD boreholes were used in the past to dispose high-specific-activity waste that required greater confinement depths than standard shallow-land disposal.

\subsection{Approaches to Closure and Monitoring}

Closure activities for waste disposal units at the Area 3 RWMS and at the 92-ac area and the expansion area of the Area 5 RWMS will follow a systematic process consisting of ten steps discussed below. The first two steps - preliminary assessment and initial planning - determine the depth to which each remaining activity has to be conducted or which documents have to be developed.

Monitoring is conducted at the Area 3 and Area 5 RWMSs via sensors and analysis of samples for various reasons: to satisfy regulatory requirements, to ensure the integrity of covers over waste disposal units, to sufficiently forewarn management and regulators of any need for mitigating actions and to record the utility of such actions, and to provide data for routine maintenance of the PAs and CAs. Review of monitoring data for maintenance of the PAs and CAs is an iterative process that will ultimately dictate which monitoring data should continue to be collected and which monitoring data are no longer required.

The approach to monitoring in this document references many other documents for details of various components of the section. Particularly relevant are (1) the Routine Radiological Environmental Monitoring Plan (RREMP) (BN, 2003a) for the decision-based approach to identify key monitoring data that must be collected, and (2) specific monitoring Organization Instructions (OIs), which are required to maintain consistency and comparability of data from year to year.

\footnotetext{
1 The practice has been to designate an excavation as either a "trench" or "pit," the difference being that a truck could be turned around in a pit. (This equates to greater than $30 \mathrm{~m}$ [100 ft] wide for a pit and less than $30 \mathrm{~m}$ [100 ft] wide for a trench.) Trench designations are prefixed with a "T," whereas pit designations are prefixed with a "P." The designations are suffixed with either a "U" or "C" to indicate "unclassified" waste or "classified" material, respectively.

2 Trenches T04C and T04C-1 are herein considered to be discrete, resulting in 25 disposal units within the 92-acre area, rather than 24 disposal units as is sometimes referenced.
} 


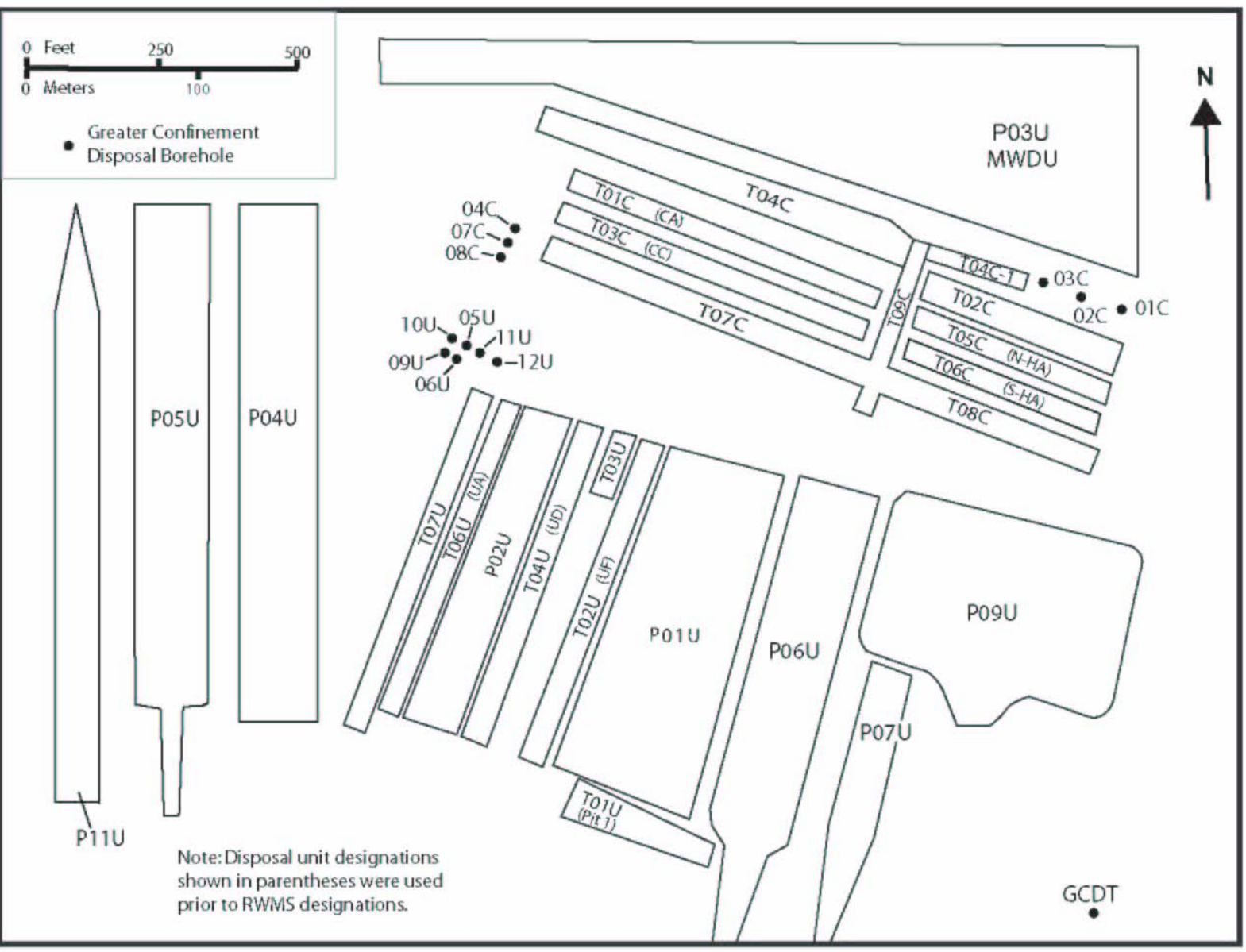

Figure 1.4 Locations of the Greater Confinement Disposal boreholes at the Area 5 Radioactive Waste Management Site

\subsubsection{Approach to Closure}

Responsibilities for closure at the Area 5 RWMS are shared between the NNSA/NSO Waste Management Division (WMD) and the BN Waste Management Project. Closure activities associated initially with closure of disposal units within the 92-ac area and the Area 3 RWMS, and later within the expansion area, will follow a ten-step approach. Each step listed below will lead to the next step in sequence.

\section{Preliminary Assessment}

Assessment data regarding the disposal units to be closed and the surrounding area will be gathered, compiled, and summarized in a report. Data may be acquired through on-site inspection; interviews; and review of literature, data bases, historical records, manifests, waste profiles, maps, engineering drawings, photographs, and other media. 


\section{Initial Planning}

On the basis of the preliminary assessment, initial planning will be conducted to include as necessary: stating the problem, defining the boundaries of the investigation, developing or refining a conceptual model, identifying data requirements, identifying the approach to acquiring required data, and identifying the approach to using acquired data. For closure of disposal units regulated under the Resource Conservation and Recovery Act (RCRA) or a Nevada Division of Environmental Protection (NDEP)-issued permit, or identified in the Federal Facility Agreement and Consent Order (FFACO) (1996), the NDEP is involved in the planning process and approves the results of planning.

\section{Characterization Plan}

On the basis of initial planning, a plan for acquiring required data will be developed. The characterization plan may include a field plan, sampling and analysis plan, a health and safety plan, and any other sub-plans required to acquire the data. For closure of disposal units regulated under the RCRA or an NDEP-issued permit, or identified in the FFACO (1996), NDEP will review and approve the characterization plan.

\section{Implement Characterization Plan}

The various activities identified in the characterization plan will be conducted in this step of the closure approach.

\section{Characterization Report}

Results of implementing the characterization plan will be presented in a characterization report. For closure of disposal units regulated under RCRA or an NDEP-issued permit, or identified in the FFACO (1996), the NDEP reviews and approves the characterization report.

\section{Closure Plan}

A plan for closing the disposal units is developed based on results presented in the characterization report. The closure plan will identify the assumptions and regulatory requirements, describe the disposal units and the physical environment in which they are located, describe the design of the closure cover, and define the approach and schedule for both closing and monitoring the units. The closure plan for disposal units with hazardous constituents will follow guidance in Title 40 Code of Federal Regulations (CFR) 264 Subpart N. The NDEP reviews and approves the closure plan for disposal units regulated under RCRA or an NDEPissued permit, or identified in the FFACO (1996). The closure plan for disposal units with only LLW will be similar to the closure plan for regulated disposal units.

\section{Implement Closure Plan (Construction)}

Construction of the final closure cover based on the closure plan will be conducted.

\section{Closure Report}

A closure report will be developed following construction of the closure cover. This report will discuss the construction process and the as-built conditions of the closure cover. The NDEP reviews and approves the closure plan for disposal units regulated under RCRA or an NDEPissued permit, or identified in the FFACO (1996). 


\section{Acknowledge Completion}

On the basis of the closure report, an acknowledgment of completion is presented based on information in the closure report. The NDEP presents the acknowledgment for closure of disposal units regulated under RCRA or an NDEP-issued permit, or identified in the FFACO (1996). The NNSA/NSO presents the acknowledgment for closure of all other disposal units.

\section{Post-Closure Monitoring and Maintenance}

Following completion, post-closure monitoring and maintenance of the final closure cover will be conducted as specified in the closure plan specific to that closure.

\subsubsection{Approach to Monitoring}

The approach to monitoring at the Area 3 and Area 5 RWMSs is to meet data monitoring requirements for operation and improvement of waste operations. Specific monitoring is required under a variety of regulatory drivers including federal regulations and DOE orders. Monitoring data are needed to evaluate radiation doses to the general public; for PA performance confirmation, validation, and maintenance; to demonstrate compliance with regulatory drivers; and to evaluate the actual performance of the RWMSs. Monitoring provides data to ensure the integrity and performance of waste disposal units. The monitoring program is designed to forewarn management and regulators of any failure of the units or covers and need for mitigative actions.

This ICMP describes the program for monitoring direct radiation, air, vadose zone, biota, groundwater, meteorology, and subsidence at the Area 3 and Area 5 RWMSs during the operational closure period (current), and the final closure and active institutional control periods.

Radiation is continuously monitored at five locations at the Area 3 RWMS and at ten locations within the Area 5 RWMS. Air monitoring for radionuclides other than radon is conducted at several locations at each RWMS using air samplers, whereas radon is passively monitored at six locations at each RWMS and at several background locations. Radon flux through waste covers is measured annually at various locations at each RWMS and at background locations. Vadose zone monitoring for soil-water content and soil-water potential is conducted continuously in waste covers, beneath waste units, and at lysimeter facilities. Surface water runoff is monitored at flumes, and at the floor of a nuclear subsidence crater. Tritium in soil-gas moisture is monitored annually in a GCD borehole (GCD-05U) at the Area 5 RWMS, that contains a large tritium source. Biota are monitored annually for tritium. Groundwater is sampled semiannually at three wells surrounding the Area 5 RWMS for radioactive and nonradioactive constituents under NDEPs interim status of the Pit 3 Mixed Waste Disposal Unit (MWDU) permit. In addition, meteorology parameters are continuously monitored at both RWMSs, and measurement of waste cover subsidence is conducted monthly at both RWMSs. 


\subsection{Assumptions}

Assumptions related to closure and monitoring of the Area 3 and Area 5 RWMSs are given in the life cycle baseline of the NNSA/NSO WMD. Pertinent programmatic, scheduling, and funding assumptions from the Waste Management baseline are reproduced below, in addition to assumptions that relate more to the approach and responsibility for closure and monitoring described herein.

\subsubsection{Assumptions Related to Closure}

- Funding will be available to complete closure-related activities at the scheduled times.

- Closure of all disposal units within the Area 3 and Area 5 RWMSs, regardless of waste type, will be included in the NNSA/NSO WMD baseline.

- Activities related to final closure of the Area 3 and Area 5 RWMSs will be under the management and technical direction of the NNSA/NSO WMD.

- The ICMP will address closure of all disposal units at the Area 3 and Area 5 RWMSs, including disposed LLW (asbestos, hydrocarbon-impacted, and regular LLW), disposed MLLW, and indefinitely stored classified materials.

- Individual closure plans will be drafted for the Pit 3 MWDU, Corrective Action Unit (CAU) 111, the asbestiform waste pits, the LLW units, and the TRU waste units.

- The closure plans for disposal units containing hazardous constituents will incorporate conditions of Title 40 CFR 265.310, RCRA Permit NEV HW009, DOE O 435.1, the Area 5 RWMS DAS, Title 40 CFR 191, and other applicable regulations as appropriate.

- The NDEP will approve adding excess soil on and between disposal units under their purview.

- Routine maintenance, including adding soil between and on operational closure covers, will continue until final closure.

- Soil backfill will be the engineered barrier for the GCD boreholes that contain waste or classified materials.

- GCD boreholes will be closed according to the regulations pertaining to the type of waste they contain, such as Title 40 CFR 191 for transuranic (TRU) waste.

- The NNSA/NSO will approve all documents required for final closure of all disposal units at the Area 3 and Area 5 RWMSs.

- The NDEP and the NNSA/NSO will approve all documents required for final closure of regulated disposal units at the Area 3 and Area 5 RWMSs.

- Activities related to final closure of the Area 5 RWMS 92-ac area will occur from fiscal year (FY) 2005 through FY 2010.

- Closure construction at the Area 5 RWMS 92-ac area will be completed in FY 2009, except for those units expected to still be operational.

- Final closure activities for the Area 5 RWMS expansion area will occur between FY 2019 and FY 2021.

- Closure construction at the Area 5 RWMS expansion area will be completed in FY 2021.

- Final closure activities at the Area 3 RWMS will occur between FY 2006 and FY 2008.

- No waste will be accepted in the current disposal areas after FY 2021. 


\subsubsection{Assumptions Related to Monitoring}

- Environmental monitoring will continue through FY 2021 according to the ICMP; after FY 2021, environmental monitoring will continue under long-term surveillance and maintenance (LTSM).

- RCRA groundwater monitoring will continue (unless an exemption is granted from NDEP) during the operational phase of the Pit 3 MWDU.

- Post-closure monitoring of the Area 5 RWMS 92-ac area will commence in FY 2010 and continue at least through FY 2021 according to RCRA requirements.

\subsubsection{Assumptions Related to Long-Term Surveillance and Maintenance}

- Active institutional control of the Area 5 RWMS 92-ac site will start after final closure in FY 2010 and continue for a period of 111 years (through FY 2121).

- An exemption from RCRA groundwater monitoring requirements will be obtained after final closure of the Pit 3 MWDU within the Area 5 RWMS 92-ac area.

- Active institutional control of the Area 5 RWMS expansion area will start after final closure in FY 2021 and continue for a period of 100 years (through FY 2121).

- Active institutional control of the Area 3 RWMS will start after final closure in FY 2008 and continue for a period of 100 years (through FY 2108).

- Passive institutional control of closed sites will start after active institutional control and continue indefinitely.

\subsection{Closure Cost Estimate}

The cost of final closure of the Area 3 and Area 5 RWMSs depends on many factors that as of now are too uncertain to allow an estimate. One factor that will have a large impact on the cost of closing disposal units in the Area 5 RWMS is whether excess native soil can be placed on and between existing operational closure covers as part of site operations. Placement of soil on regulated disposal units, and in close proximity of regulated units, is contingent on approval from the NDEP.

An estimate of the cost of closure of all disposal units within the Area 5 RWMS 92-ac area will be possible after title design of the final closure cover and grading plan, tentatively scheduled for FY 2006. For regulated disposal units within the 92-ac area, the state and federal governments are exempt from the requirements of Title 40 CFR 264.142 to submit a cost estimate for closure (Title 40 CFR 264.140 [c]).

An estimate of the cost of closure of all disposal units within the Area 3 RWMS will be possible after title design of the final closure covers and grading plan for that facility. See Section 1.8, Closure and Monitoring Schedule. 


\subsection{Monitoring Cost Estimate}

During the operational and closure periods, the monitoring activities and costs are unchanged from the current form. Direct radiation monitoring, air monitoring, radon flux measurements, biota monitoring, meteorology monitoring, vadose zone moisture monitoring, soil-gas moisture monitoring for tritium, groundwater monitoring (none after closure of Pit 3), and subsidence monitoring continue during this period.

Monitoring during the period of active institutional control is expected to continue, but be reduced to air and soil-gas monitoring for tritium, radon flux measurements, meteorology monitoring, vadose zone moisture monitoring, and subsidence monitoring. The value and need for specific monitoring activities will be evaluated during this period so the monitoring activities may change. Groundwater monitoring is expected to be discontinued when NDEP issues the groundwater monitoring exemption. The annual cost for monitoring activities during active institutional control is expected to be approximately half of the cost of monitoring during the operational and closure periods.

\subsection{Closure and Monitoring Schedule}

Activities associated with final closure of the Area 5 RWMS 92-ac site are scheduled to start in FY 2005 and be completed in FY 2010 (Table 1.1). Activities associated with final closure of the Area 5 expansion area north of the 92-ac site are scheduled to start in FY 2019 and be completed in FY 2021. Final closure activities at the Area 3 RWMS are expected to occur between FY 2006 and FY 2008. These latter closures will follow the same ten-step sequence expressed in Table 1.1 for the Area 5 RWMS 92-ac area. Monitoring and maintenance activities specified for active institutional control will start after final closure and continue for the assumed time periods, or for mixed waste, also according to conditions negotiated with the NDEP (see Section 1.2).

\subsection{Coordination with Operational Activities}

In FY 2004, a Six Sigma Process Improvement Project was conducted that may lead to a decision to close the Area 3 RWMS within the next few years. Activities related to closure of the Area 3 RWMS will occur after all waste disposal operations have ceased, precluding the need for coordination with operations.

Disposal operations are expected to continue within the Area 5 RWMS 92-ac area for several years and within the Area 5 RWMS expansion area for a longer period of time. Infrastructure to support those operations will remain in the southern and southeast parts of the 92-ac area of the Area 5 RWMS. Near-term and longer-term activities related to closure at these locations will sometimes have to be coordinated with disposal operations or maintenance. A liaison between the closure project and disposal operations will be appointed to ensure that both activities run according to cost and schedule. 
Table 1.1 Schedule of the ten-step approach for closure of the Area 5 RWMS 92-acre area

\begin{tabular}{|l|c|c|c|c|c|}
\cline { 2 - 6 } \multicolumn{1}{c|}{} & \multicolumn{4}{c|}{ Fiscal Year } \\
\hline \multicolumn{1}{c|}{ Activity } & $\begin{array}{c}\text { TRU } \\
\text { Wnits }\end{array}$ & $\begin{array}{c}\text { Pit 3 } \\
\text { MWDU }\end{array}$ & CAU 111 & $\begin{array}{c}\text { LLW } \\
\text { Units }\end{array}$ & Asbestos \\
\hline Preliminary Assessment & 2005 & 2004 & 2005 & 2005 & 2005 \\
\hline Initial Planning & 2005 & 2004 & 2005 & 2005 & 2005 \\
\hline $\begin{array}{l}\text { Characterization Plan } \\
\text { Previous }\end{array}$ & Previous & Previous & Previous & Previous \\
\hline $\begin{array}{l}\text { Implement } \\
\text { Characterization Plan }\end{array}$ & Previous & Previous & Previous & Previous & Previous \\
\hline $\begin{array}{l}\text { Characterization Report } \\
\text { Post-Closure Monitoring } \\
\text { and Maintenance }\end{array}$ & 2006 & 2006 & 2006 & 2006 & 2006 \\
\hline $\begin{array}{l}\text { Closure Plan } \\
\text { Implement Closure Plan } \\
\text { (Construction) }\end{array}$ & 2009 & 2009 & 2009 & 2009 & 2009 \\
\hline $\begin{array}{l}\text { Closure Report } \\
\text { Acknowledge (Certify) }\end{array}$ & 2010 & 2010 & 2010 & 2010 & 2010 \\
\hline
\end{tabular}

\subsection{Closure and Monitoring Plan Maintenance and Amendment}

The ICMP is scheduled to be reviewed and updated on a three-year interval (the next update after this year to be conducted in FY 2007). Significant changes in the Waste Management program could prompt an unscheduled update, or drafting and issuance of an addendum. The intent of periodically updating the various related documents is to realize the primary objective of ensuring that workers, the public, and the environment are safe during and after waste disposal operations. 
This Page Intentionally Left Blank 


\subsection{WORK SMART STANDARDS AND COMPLIANCE STRATEGY}

The Management and Operations (M\&O) contractor to the NNSA/NSO is required by contract to conduct all activities according to a set of necessary and sufficient laws, regulations, and directives. These laws, regulations, and directives form the Work Smart Standards. "Facility closure" and "environmental monitoring" are processes listed under the work activity of Radioactive Waste Management.

\subsection{Closure Standards}

The Area 3 and Area 5 RWMSs are primarily LLW disposal sites. The Area 3 RWMS includes LLW and MLLW, whereas the Area 5 RWMS includes LLW and MLLW, small amounts of TRU waste and mixed TRU (MTRU) waste, and asbestiform waste. Low-level waste and TRU waste are also stored at the Area 5 RWMS. Waste with only a radioactive component is selfregulated by the DOE. The radioactive component of mixed waste is self-regulated by the DOE, whereas the hazardous component of mixed waste is regulated by the RCRA under the authority of the U.S. Environmental Protection Agency (EPA). The NDEP has been granted the authority by the EPA to administer the RCRA in Nevada. Nevada Administrative Code (NAC) 444.8632 incorporates the federal RCRA requirements by reference (Nevada Environmental Commission [NEC], 1987). The following excerpts from the DOE Orders and other regulations for closure provide the basis for the Closure Program.

\subsubsection{DOE Order 435.1}

The DOE Order governing management of radioactive waste is 435.1. Associated with the Order are a Manual (DOE M 435.1-1) and a Guidance (DOE G 435.1-1). The DOE/NV Manual provides the requirements, roles, and responsibilities to establish the NNSA/NSO Radioactive Waste Management Program according to the Order. The DOE Manual and Guidance list the following requirements related to closure of LLW disposal cells.

- Chapter IV, Q (Closure) (1). A preliminary closure plan shall be developed and submitted to DOE/HQfor review with the Performance Assessment and Composite Analysis. The closure plan shall be updated within one year following issuance of the Disposal Authorization Statement to incorporate conditions specified in the Disposal Authorization Statement.

- $Q(1)(a)$. Closure plans shall be updated as required during the operational life of the facility.

- $Q(1)(b)$. Closure plans shall include a description of how the disposal facility will be closed to achieve long-term stability and minimize the need for active maintenance following closure and to ensure compliance with the requirements of DOE O 5400.5, "Radiation Protection of the Public and the Environment" (or 10 CFR 834, when promulgated).

- $Q(1)(c)$. Closure plans shall include the total expected inventory of wastes to be disposed of at the facility over the operational life of the facility. 
- $Q$ (2). Closure of a disposal facility shall occur within a five-year period after it is filled to capacity, or after the facility is otherwise determined to be no longer needed.

- $Q$ (2)(a). Prior to facility closure, the final inventory of the low-level waste disposed in the facility shall be prepared and incorporated into the PA and CA which shall be updated to support closure of the facility.

- $Q(2)(b)$. A final closure plan shall be prepared based on the inventory of waste disposed in the facility and the updated $P A$ and $C A$ prepared in support of the facility closure.

- $Q(2)(c)$. Institutional control shall continue until the facility can be released pursuant to DOE Order 5400.5, "Radiation Protection of the Public and the Environment" (or 10 CFR 834, when promulgated).

- $Q(2)(d)$. The location and use of the facility shall be filed with the local authorities responsible for land use and zoning.

\subsubsection{Title 40 CFR 265}

Performance objectives related to closure of a waste disposal unit containing only LLW are similar in principle to those specified in the RCRA Subpart N, Title 40 CFR 265.310(a) for waste disposal cells containing MLLW:

At final closure of the landfill or upon closure of any cell, the owner or operator must cover the landfill or cell with a final cover designed and constructed to:

- Provide long-term minimization of migration of liquids through the closed landfill

- Function with minimum maintenance

- Promote drainage and minimize erosion or abrasion of the cover

- Accommodate settling and subsidence so that the cover's integrity is maintained

- Have a permeability less than or equal to the permeability of any bottom liner system or natural subsoils present

In addition to the above requirements, Title 40 CFR 265.310(b) specifies that:

After final closure, the owner or operator must comply with all post-closure requirements contained in 265.117 through 265.120, including maintenance and monitoring throughout the post-closure care period. The owner or operator must:

- Maintain the integrity and effectiveness of the final cover, including making repairs to the cover as necessary to correct the effects of settling, subsidence, erosion, or other events 
- Maintain and monitor the leak detection system according to Title 40 CFR 264.301(c)(3)(iv) and (4) of this Chapter and 265.304(b), and comply with all other applicable leak detection system requirements of this part

- Maintain and monitor the groundwater monitoring system and comply with all other applicable requirements of Subpart F of this part

- Prevent run-on and runoff from eroding or otherwise damaging the final cover

- Protect and maintain surveyed benchmarks used in complying with Title 40 CFR 265.309

\subsubsection{Title 40 CFR 191}

Small amounts of TRU and MTRU wastes are disposed in GCD boreholes and one shallow-land disposal unit at the Area 5 RWMS. According to DOE M 435.1-1, TRU waste is to be disposed according to Title 40 CFR 191. With respect to the limited amounts of these wastes, the NNSA/NSO will assess the applicability of Title 40 CFR 191 to closure through the process of self regulation.

A compliance assessment document for TRU waste disposed in GCD boreholes, including a PA with respect to the requirements of Title 40 CFR 191, has been completed by Sandia National Laboratories (SNL) (Cochran et al., 2001). Title 40 CFR 191 includes both quantitative requirements and qualitative "assurance" requirements that must be met to demonstrate adequate protection of human health and the environment. The three quantitative requirements pertain to containment, individual protection, and groundwater protection. The six assurance requirements are imposed to provide additional confidence that the containment requirements will be met: (1) active institutional controls, (2) passive institutional controls, (3) monitoring, (4) engineered and natural barriers, (5) siting to avoid resources, and (6) future removal of waste. According to definitions in Title 40 CFR 191 for active and passive institutional controls, the assurance requirement of monitoring is considered to be an active control, and barriers are considered to be a passive control.

Comparison of the assurance requirements associated with Title 40 CFR 191 with closure and monitoring requirements of DOE O 435.1 and DOE M 435.1-1 indicates that measures taken to satisfy the requirements of Title 40 CFR 191 will meet or exceed requirements of the radioactive waste management Order. An assessment of the assurance requirements for TRU waste in the GCD boreholes is described in the GCD document (Brosseau, 2001). Closure and monitoring requirements of RCRA are also generally satisfied by these measures; specific requirements for closure and monitoring may be imposed by the NDEP for cells containing MTRU waste. These requirements are negotiated with the NDEP when drafting the specific closure plans.

\subsubsection{NAC 444.743}

Pits P06U and P07U are permitted Class III asbestiform low-level solid waste disposal units at the Area 5 RWMS and must meet the following requirements: 
- NAC 444.743. Final cover or closure; postclosure. A Class III site must comply with requirements set forth in NAC 444.6891 to 444.6894, inclusive, concerning closure and postclosure.

- NAC 444.6891. Requirements for design and construction of system for final cover. 1. the owner or operator of a Class I site shall install a system for a final cover which is designed to minimize infiltration and erosion. Except as otherwise provided in Subsection 2, the system must be designed and constructed to:

- (a) Have a permeability that is less than or equal to the permeability of any system for a bottom liner or natural subsoils present, or have a permeability no greater than $1 \times 10^{-5}$ centimeters per second, whichever is less;

- (b) Minimize infiltration through the closed municipal solid waste landfill unit by the use of an infiltration layer which contains at least 18 inches of earthen material; and

- (c) Minimize erosion of the final cover by the use of an erosion layer which contains at least 6 inches of earthen material which is capable of sustaining the growth of native plants.

\subsection{Monitoring Standards}

The following excerpts from the DOE Orders and other regulations for monitoring provide the basis for the Monitoring Program.

\subsubsection{DOE Order 435.1}

The DOE M 435.1-1 and DOE G 435.1-1 associated with DOE O 435.1 provide requirements and implementation guidance for air monitoring (including radon), vadose zone, meteorology, biota, direct radiation monitoring, and subsidence monitoring.

- Chapter IV, P (1) (a). Dose to representative members of the public shall not exceed 25 millirem (mrem) $(0.25 \mathrm{mSv})$ in a year total effective dose equivalent from all exposure pathways, excluding the dose from radon and its progeny in air.

- $P(1)$ (b). Dose to representative members of the public via the air pathway shall not exceed $10 \mathrm{mrem}(0.10 \mathrm{mSv})$ in a year total effective dose equivalent, excluding the dose from radon and its progeny.

- $P$ (1) (c). Release of radon shall be less than an average flux of $20 \mathrm{pCi} / \mathrm{m}^{2} / \mathrm{s}\left(0.74 \mathrm{~Bq} / \mathrm{m}^{2} / \mathrm{s}\right)$ at the surface of the disposal facility. Alternatively, a limit of $0.5 \mathrm{pCi} / \mathrm{l}(0.0185 \mathrm{~Bq} / \mathrm{l})$ of air may be applied at the boundary of the facility.

- $\quad R(3)(a)$. The site-specific performance assessment and composite analysis shall be used to determine the media, locations, radionuclides, and other substances to be monitored. 
- $\quad R$ (3) (b). The environmental monitoring program shall be designed to include measuring and evaluating releases, migration of radionuclides, disposal unit subsidence, and changes in disposal facility and disposal site parameters which may affect long-term performance.

- $R$ (3) (c). The environmental monitoring programs shall be capable of detecting changing trends in performance to allow application of any necessary corrective action prior to exceeding the performance objectives in this Chapter.

\subsubsection{DOE Order 450.1}

DOE Order 450.1 (which replaced DOE O 5400.1) and Guidance Document DOE/EH-0173T (DOE, 1991) provide requirements for air monitoring (including radon), groundwater, vadose zone, meteorology, biota, and direct radiation monitoring.

- Chapter IV, 5b. (1). Environmental surveillance shall be designed to satisfy one or more of the following program objectives:

- $5 b$ (1)(a) Verify compliance with applicable environmental laws and regulations

- $5 b$ (1)(b) Verify compliance with environmental commitments made in Environmental Impact Statements, Environmental Assessments, Safety Analysis Reports, or other official DOE documents

- $5 b(1)(c)$ Characterize and define trends in the physical, chemical and biological condition of environmental media

- $5 b(1)(d)$ Establish baselines of environmental quality

- $5 b$ (1)(e) Provide a continuing assessment of pollution abatement programs

- $5 b(1)(f)$ Identify and quantify new or existing environmental quality problems

\subsubsection{Title 40 CFR 61}

Title 40 CFR 61 provides requirements for radiological air monitoring (including radon) and direct radiation monitoring.

- Subpart H, National Emission Standards for Emission of Radionuclides Other Than Radon from Department of Energy Facilities, Section 61.92 Standard. Emissions of radionuclides to the ambient air from Department of Energy facilities shall not exceed those amounts that would cause any member of the public to receive in any year an effective dose equivalent of 10 mrem/year.

- Subpart Q, National Emission Standards for Radon Emissions from Department of Energy Facilities, Section 61.192 Standard. No source at a Department of Energy facility shall emit 
more than $20 \mathrm{pCi} / \mathrm{m}^{2} / \mathrm{s}$ of radon-222 as an average for the entire source, into the air. This requirement will be part of any Federal Facilities Agreement reached between Environmental Protection Agency and Department of Energy.

To date, neither the Area 3 nor the Area 5 RWMSs contain 11.e.(2) waste, so Subpart Q does not apply. However, Subpart Q is included because of the potential to receive 11.e.(2) waste in the future.

\subsubsection{Title 40 CFR 264}

The Area 5 RWMS 92-ac area groundwater monitoring program is guided in part by the following sections of Title 40 CFR 264, Subpart F, unless as specified in the "Outline of a Comprehensive Groundwater Monitoring Program" (BN, 1998a), and the Annual Groundwater Monitoring Data Report (e.g., BN, 2004a) in agreement between NNSA/NSO and NDEP:

- 264.97, General groundwater monitoring requirements

- 264.98, Detection monitoring program

- 264.99, Compliance monitoring program

- 264.100, Corrective action program

- 264.101, Corrective action for solid waste management units

\subsubsection{Title 40 CFR 265}

The Area 5 RWMS groundwater monitoring program is driven in part by the following sections of Title 40 CFR 265, Subpart F, unless as specified in the "Outline of a Comprehensive Groundwater Monitoring Program" (BN, 1998a), and the Annual Groundwater Monitoring Data Report (e.g., BN, 2004a) in agreement between NNSA/NSO and NDEP:

- 265.90, Applicability

- 265.91, Groundwater monitoring system

- 265.92, Sampling and analysis

- 265.93, Preparation, evaluation, and response

- 265.94, Record keeping and reporting

\subsubsection{Title 40 CFR 191}

Title 40 CFR 191 provides the following general monitoring requirement:

- Section 191.14 Assurance Requirements, (b). Disposal systems shall be monitored after disposal to detect substantial and detrimental deviations from expected performance. This monitoring shall be done with techniques that do not jeopardize the isolation of the wastes and shall be conducted until there are no significant concerns to be addressed by further monitoring. 


\subsection{Compliance Strategy}

The strategy for meeting the performance standards and a description of the final closure design are summarized below. The strategy assumes that operational closure covers have been placed on all filled disposal units.

- Screened native soil will be placed for the final closure cover of disposal units within the Area 5 RWMS 92-ac area.

- The closure cover will be graded to slope approximately 2 percent southwest to promote drainage off and away from the RWMS.

- The cover will be seeded and/or planted with vegetation.

- Performance monitoring devices will be installed in the cover or in a representative, nearby cover.

- A facility monitoring plan will be developed and implemented.

- Grading, drainage, and monitoring will be integrated with the RCRA CAU 111 and the Pit 3 MWDU to ensure that there are no adverse impacts to either unit.

The properties of the native soil used for the final closure cover and base of Pit 3, along with the design of the landfill, are further discussed in Crowe (2004).

The closure plan is based on closure of the Pit 3 MWDU concurrent with closure of the 92 ac at the Area 5 RWMS, which requires integration of the Pit 3 MWDU, CAU 111, and all of the operationally closed RWMS facilities. The proposed integrated cover design uses a final monolayer closure cover over all of the disposal units. The final 92-ac area RWMS closure cover is referred to as a "monolayer-evapotranspiration" (ET) cover because of the absence of layers and the two active processes in the cover that remove moisture from the soil - evaporation and transpiration by plants. The final RWMS closure cover will include filling drainage channels between disposal units and using drainage channels around the perimeter of the Area 5 RWMS Facility. 
This Page Intentionally Left Blank 


\subsection{SITE CHARACTERISTICS}

The geography, demographics, and other physical characteristics of the NTS, Yucca Flat, Frenchman Flat, and surrounding areas are collectively important to the RWMSs, especially in terms of meeting performance objectives defined in DOE M 435.1-1.

\subsection{Geography}

The NTS, located in Nye County, Nevada, $104 \mathrm{~km}$ (65 mi) northwest of Las Vegas, comprises approximately 3,561 square $\mathrm{km}\left(\mathrm{km}^{2}\right)\left(1,375\right.$ square $\left.\mathrm{mi}\left[\mathrm{mi}^{2}\right]\right)$ of land reserved to the jurisdiction of the DOE under four land withdrawals (DOE, 1996). The primary use of the NTS between 1951 and 1992 was testing of nuclear weapons. Since 1992, subcritical experiments and other defense-related and nondefense-related activities have been and continue to be conducted at the NTS. Mercury, in the southeast corner of the NTS, is the primary support facility for the NTS. Other, smaller communities, including Amargosa Valley, Lathrop Wells, and Indian Springs, are also present within a few tens of $\mathrm{km}$ (tens of mi) of the NTS, along the U.S. Highway 95 corridor (Figure 1.1). The primary valleys on the NTS are Yucca Flat, Frenchman Flat, and Jackass Flats. Yucca Flat is in the northeast part of the NTS, Frenchman Flat is in the southeast part of the NTS, and Jackass Flats is in the southwest part of the NTS.

Yucca Flat is an elongated, sediment-filled basin that trends roughly north-south; the long axis is approximately $27 \mathrm{~km}(17 \mathrm{mi})$ and the short axis is approximately $16 \mathrm{~km}(10 \mathrm{mi})$. Yucca Flat is bounded by Quartzite Ridge and Rainier Mesa on the north, the Halfpint Range on the east, the Massachusetts Mountains and Control Point Hills on the south, and Mine Mountain and the Eleana Range on the west. The Yucca Flat basin slopes from the north at an elevation of approximately 1,402 $\mathrm{m}(4,600 \mathrm{ft})$ to the south toward Yucca Playa, the lowest part of the basin at an elevation of approximately 1,189 $\mathrm{m}(3,900 \mathrm{ft})$. Yucca Flat was one of several primary nuclear test areas and is marked essentially the length of the valley with craters (Figure 3.1).

Frenchman Flat is a roughly circular basin bounded by the Massachusetts Mountains on the north, the Buried Hills and Ranger Mountains on the east and southeast, Mount Salyer on the west, and Mercury Ridge and Red Mountain on the south (Figure 3.2). Elevations range between $1,600 \mathrm{~m}(5,250 \mathrm{ft})$ in the surrounding mountains to $939 \mathrm{~m}(3,080 \mathrm{ft})$ at Frenchman Playa in the center of the basin. Frenchman Flat was one of several primary nuclear test areas. Atmospheric tests were conducted on the playa and a limited number of underground tests were conducted in the northern part of the basin.

\subsection{Demography}

Demographic issues for use of the Area 3 and Area 5 RWMSs include the distribution of the population in and around the NTS, as well as the current and proposed uses of the land adjacent to the NTS. 


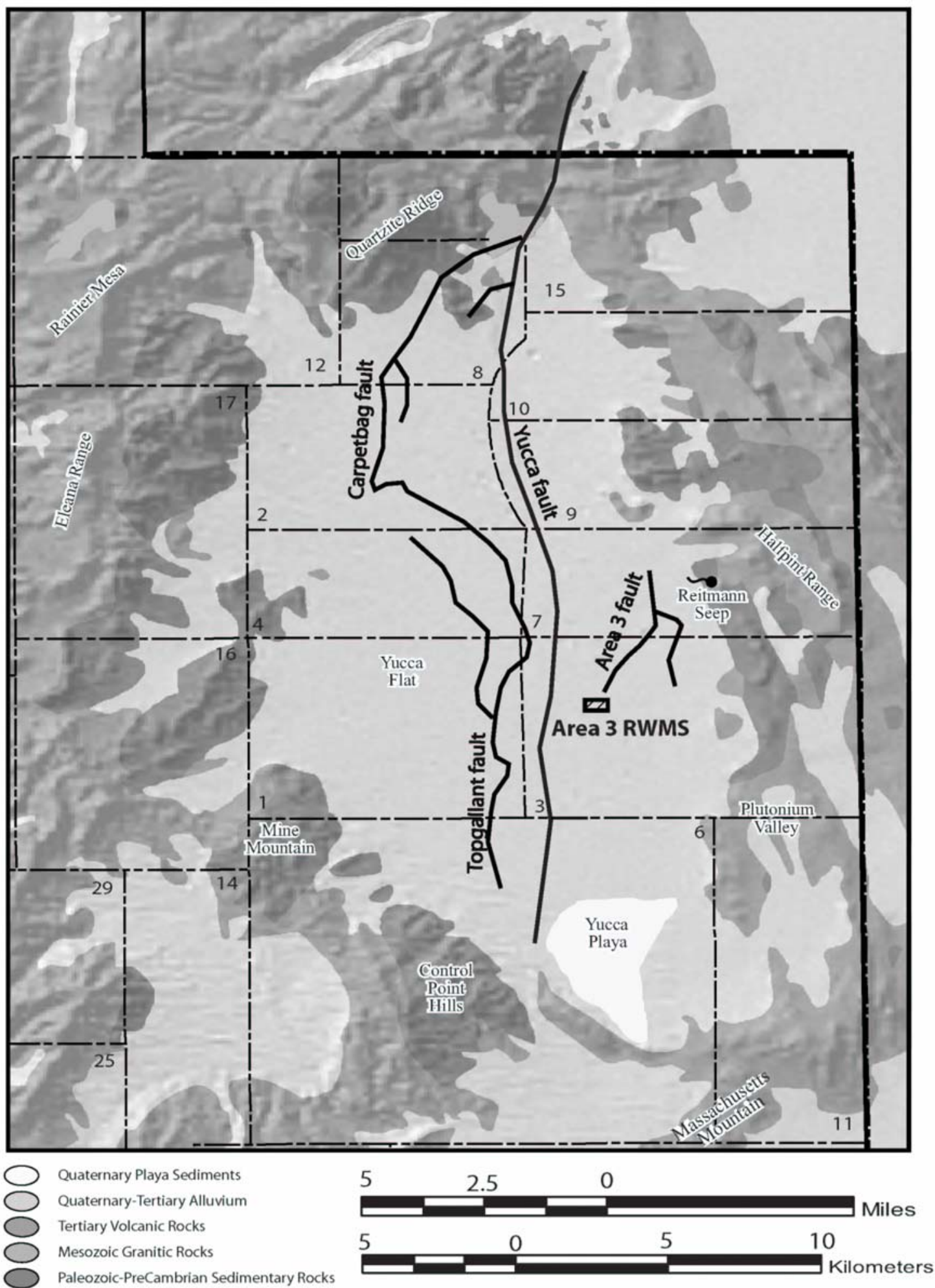

Figure 3.1 General geologic map of Yucca Flat and vicinity 


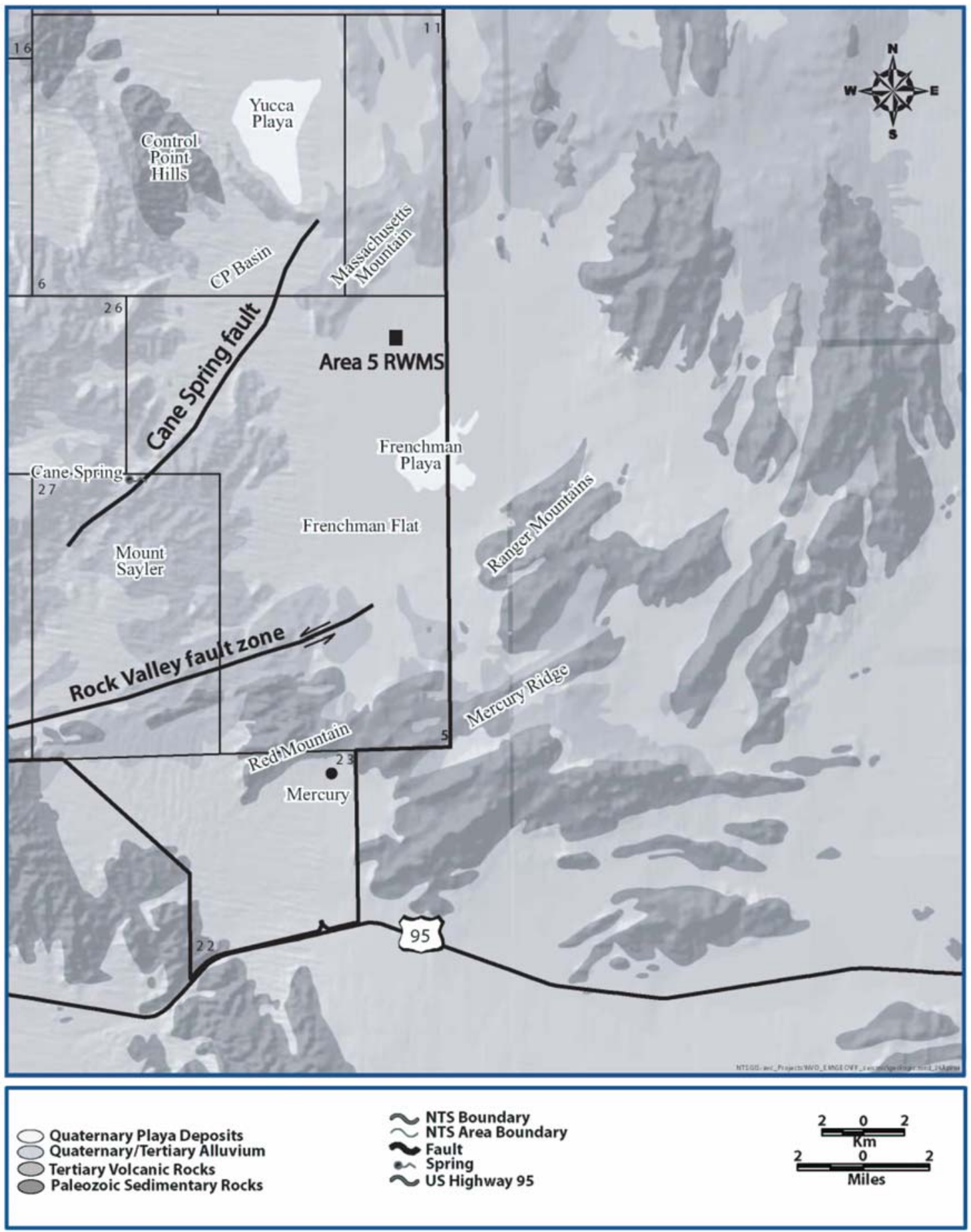

Figure 3.2 General geologic map of Frenchman Flat and vicinity 


\subsubsection{Population Distribution}

On the basis of a 1994 survey, 90 percent of the NTS workforce resided in Clark County, 7 percent resided in Nye County, and the remaining 3 percent resided in other counties or states (DOE, 1996). Although a more recent survey is not available, current percentages are likely similar to those of the 1994 survey. Estimates prepared by the Nevada State Demographer (http://www.nsbdc.org/demographer/pubs/estimates.html) showed that in 2003, the population of Clark County was 1.62 million, with the overwhelming majority (approximately 96 percent) of residents living in the Las Vegas Valley.

According to estimates prepared by the Nevada State Demographer (http://www.nsbdc.org/demographer/pubs/estimates.html), the population of Nye County in 2003 was 36,651. Pahrump, located approximately $64 \mathrm{~km}(40 \mathrm{mi})$ from the NTS, is the largest and most rapidly growing community in Nye County. In 2003, the population of Pahrump (at 28,847 ) accounted for approximately 79 percent of the Nye County population.

Amargosa Valley, located $3.2 \mathrm{~km}(2 \mathrm{mi})$ south of the southwestern corner of the NTS, is the nearest rural population center to the NTS. According to estimates prepared by the Nevada State Demographer (http://www.nsbdc.org/demographer/pubs/estimates.html), the population of Amargosa Valley in 2003 was 1,169. Other small rural population centers near the NTS are Beatty and Indian Springs. Indian Springs has shown an increase in population, whereas the population of Beatty has decreased.

The population of the Las Vegas Valley and the rural centers is driven primarily by opportunities or resources, or both. Las Vegas offers primarily employment associated with the gaming and construction industries, and has become a preferred retirement center. Amargosa Valley offers ranching and agriculture. Pahrump is a preferred retirement center and continues to serve as a bedroom community for Las Vegas and the NTS. The population of Beatty is largely supported by tourism. The population of Indian Springs is largely supported by the military.

Aside from changes in population resulting from variances in primary supporting industries, the populations of rural communities near the NTS would likely respond to changes in activities at the NTS and surrounding land. The NTS is currently and for the foreseeable future withdrawn from all forms of appropriation. Uses of the NTS will continue to be governed by land resource constraints. Constraints at the NTS include weapons testing, radioactive waste management, contaminated areas, and ecological sensitivity. Current uses of the NTS will likely continue for the foreseeable future.

\subsubsection{Uses of Adjacent Land}

Native Americans were the first to use the lands now within the NTS. The Shoshone lived at springs in the northern NTS and the Paiutes lived at springs in the southern NTS. Later, early settlers established cattle ranches and wild horse capture operations at local springs (Reno and Pippin, 1985). Mining operations have occurred on the NTS at the Oak Spring District, Mine 
Mountain District, and Wahmonie District (Reno and Pippin, 1985). In 1928, Cane Spring supported the 1,500-person mining community of Wahmonie (Allred et al., 1963).

Ranching and mining remain important land uses in southern Nevada. Recreational activities and irrigation-based agriculture have become important land uses in southern Nevada. Provided that the NTS remains withdrawn from all forms of appropriation, these activities will likely not have a significant impact on the NTS. Three-fourths of the land immediately adjacent to the NTS is controlled by the U.S. Air Force. The remaining fourth is managed by the U.S. Bureau of Land Management. This federal use and management of the land further buffer the NTS from external influence.

\subsection{Meteorology}

Detailed discussions on meteorology and climatology specific to the Area 3 and Area 5 RWMSs are presented in the PAs for those sites (Shott et al., 1998; 1997; 1995) and the annual monitoring report (BN, 2004b). Those discussions are summarized below.

\subsubsection{Precipitation}

The NTS is between the northern boundary of the Mojave Desert and the southern limits of the Great Basin Desert. This "Transitional Desert" is considered to be typical of either the Dry Midlatitude or Dry Subtropical climatic zones. The climate is characterized by low precipitation, a large diurnal temperature range, a large evaporation rate, and moderate to strong winds.

Most precipitation in the Transitional Desert occurs in winter and summer. Winter precipitation is generally associated with transitory low-pressure systems originating from the west and occurring as uniform storms over large areas. Summer precipitation is generally associated with convective storms originating from the south or southwest and occurring as intense local storms. The average annual precipitation ranges between 7.6 and 25.4 centimeters $(\mathrm{cm})(3$ and 10 inches [in]), depending on elevation. Lower values of this range are typical in valleys, whereas higher values are typical in the surrounding mountains. The average annual precipitation in Yucca Flat is $16.3 \mathrm{~cm}$ (6.4 in), based on a 36-year record between 1961 and 1996 at the Buster-Jangle meteorology station, which is located approximately $4.8 \mathrm{~km}(3 \mathrm{mi})$ northwest of the Area 3 RWMS at an elevation of 1,218 m (4,060 ft) (Shott et al., 1997). The average annual precipitation in Frenchman Flat is $12.7 \mathrm{~cm}$ (5.0 in) based on a 30-year record between 1963 and 1993 at

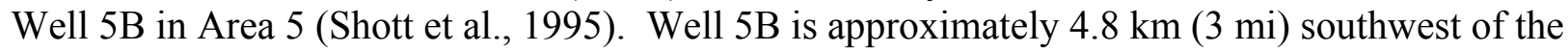
Area $5 \mathrm{RWMS}$, at an elevation of $927 \mathrm{~m}(3,090 \mathrm{ft})$.

\subsubsection{Temperature}

Average daily temperatures at the NTS range between 2 degrees Celsius $\left({ }^{\circ} \mathrm{C}\right)(35$ degrees Fahrenheit $\left.\left[{ }^{\circ} \mathrm{F}\right]\right)$ in January to $24^{\circ} \mathrm{C}\left(75^{\circ} \mathrm{F}\right)$ in August. Large daily fluctuations are common on the valley floors. At Yucca Playa, over a 16-year period between 1962 and 1978, the daily maximum air temperatures ranged from $0^{\circ} \mathrm{C}\left(32^{\circ} \mathrm{F}\right)$ in winter to $40^{\circ} \mathrm{C}\left(104^{\circ} \mathrm{F}\right)$ in summer. The daily minimum air temperatures ranged from $-15^{\circ} \mathrm{C}\left(5^{\circ} \mathrm{F}\right)$ in winter to $25^{\circ} \mathrm{C}\left(77^{\circ} \mathrm{F}\right)$ in summer. 
The Yucca Playa meteorology station is approximately $11.2 \mathrm{~km}(7 \mathrm{mi})$ south of the Area 3

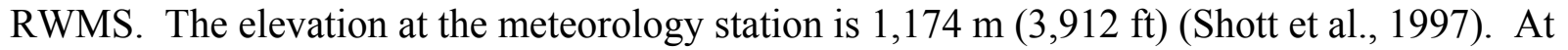
the Area 5 RWMS, the daily maximum temperature ranged from $12^{\circ} \mathrm{C}\left(54^{\circ} \mathrm{F}\right)$ in winter to $36^{\circ} \mathrm{C}$ $\left(97^{\circ} \mathrm{F}\right)$ in summer. The daily minimum air temperatures ranged from $-12^{\circ} \mathrm{C}\left(10^{\circ} \mathrm{F}\right)$ in winter to $17^{\circ} \mathrm{C}\left(63^{\circ} \mathrm{F}\right)$ in summer (Magnuson et al., 1992). The Area 5 RWMS is at an elevation of about $960 \mathrm{~m}(3,200 \mathrm{ft})$.

\subsubsection{Potential Evapotranspiration}

Potential evapotranspiration (PET) at the NTS is high because of the large incident solar radiation and wind. PET is evapotranspiration at a potential, or energy-limiting rate; it is calculated using any of a number of available equations. The average annual PET calculated using the Penman equation (Doorenbos and Pruitt, 1977) and data collected from the Area 3 and Area 5 RWMS meteorology stations is $163 \mathrm{~cm}$ (64 in) and $157 \mathrm{~cm}$ (62 in), respectively. PET is slightly higher in Area 3 than in Area 5 because Area 3 has greater wind speeds than Area 5. Average annual precipitation at Area 3 and Area 5 is 165 millimeters $(\mathrm{mm})(6.5 \mathrm{in})$ and $127 \mathrm{~mm}$ (5.0 in), respectively. The greater the ratio between PET and precipitation, the greater is the evaporative demand in a given environment. This average ratio at Area 3 and Area 5 is 9.8 and 12.4, respectively. These rates are indicative of extremely evaporative conditions.

\subsubsection{Wind}

Wind speed and direction were recorded at the Yucca Playa meteorology station between 1962 and 1978, and at the Well 5B meteorology station between 1983 and 1993. Winds are primarily southerly during the summer months and northerly during the winter months. Wind speeds tend to be greater in the spring than in the fall. At the Yucca Playa station, the average annual wind speed was $3.2 \mathrm{~m}$ per second $(\mathrm{m} / \mathrm{s})(7.2 \mathrm{mi}$ per hour $[\mathrm{mph}])$; the maximum wind speed exceeded $27 \mathrm{~m} / \mathrm{s}(60 \mathrm{mph})$. In 1999, average daily wind speed recorded at the Area 3 RWMS meteorology station at a height of $3 \mathrm{~m}(10 \mathrm{ft})$ above ground level was $3.0 \mathrm{~m} / \mathrm{s}(6.7 \mathrm{mph})$, and the maximum wind speed recorded was $21.6 \mathrm{~m} / \mathrm{s}(48 \mathrm{mph})(\mathrm{BN}, 2004 \mathrm{~b})$. In 1999, average daily wind speed recorded at the Area 5 RWMS meteorology station at a height of $3 \mathrm{~m}(10 \mathrm{ft})$ above ground level was $2.5 \mathrm{~m} / \mathrm{s}(5.6 \mathrm{mph})$, and the maximum wind speed recorded was $16.7 \mathrm{~m} / \mathrm{s}(37 \mathrm{mph})(\mathrm{BN}$, 2004b).

\subsection{Ecology}

Descriptions of plant and animal species and communities near the Area 3 and Area 5 RWMSs are presented in the PAs for those sites (Shott et al., 1997; 1998, 1995). Additional detailed discussions of NTS ecology are presented in Wills and Ostler (2001).

\subsubsection{Vegetation}

The Transitional Desert includes vegetation associations of both the Mojave Desert and the Great Basin Desert. Communities of the Mojave Desert occur over the southern third of the NTS, on bajadas and mountain ranges at elevations below about $1,200 \mathrm{~m}(4,000 \mathrm{ft})$. They are limited to 
areas with mean annual minimum temperatures greater than $-2^{\circ} \mathrm{C}\left(28^{\circ} \mathrm{F}\right)$ and mean annual precipitation less than $18.3 \mathrm{~cm}$ (7.2 in) (O'Farrell and Emery, 1976). Mojave Desert communities can have highly variable floristic compositions, but all are dominated by creosote bush and variable co-dominant shrubs. Shrub coverage varies from 7 to 23 percent for Mojave Desert communities on the NTS (Beatley, 1976). Plant communities near the Area 5 RWMS are dominated by creosote bush (Ostler et al., 2000).

Plant communities in Yucca Flat are dominantly Transitional Desert communities, although a few Mojave Desert assemblages are present. Plant communities near the Area 3 RWMS are similar to the desertthorn-hopsage or saltbush-winterfat assemblages (Winkel et al., 1995), and include desertthorn, Mormon tea, winterfat, fourwing saltbush, and littleleaf horsebrush (Hunter, 1992 [unpublished]; Winkel et al., 1995; Ostler et al., 2000).

Additional discussion on NTS vegetation can be found in Wills and Ostler (2001).

\subsubsection{Plant Rooting}

Rooting depths of Mojave Desert or Transitional Desert plants at the NTS are concentrated near the surface, likely an adaptation to maximize capture of infiltration (Winkel et al., 1995; Hansen and Ostler, 2003). Wallace and Romney (1972) described root systems of several plants excavated from a wash in Rock Valley on the NTS. Creosote bush roots reached $168 \mathrm{~cm}$ (66 in) below surface, desertthorn roots reached $122 \mathrm{~cm}$ (48 in) below surface, Mormon tea roots reached $91 \mathrm{~cm}$ (36 in) below surface, and winterfat roots reached $64 \mathrm{~cm}$ (25 in) below surface. Wallace et al. (1980) excavated root systems of several Mojave Desert species at the NTS. The roots were distributed in the top $51 \mathrm{~cm}$ (20 in), except for fourwing saltbush and shadscale; less than 2 percent of the roots of these two species were found below $51 \mathrm{~cm}(20 \mathrm{in})$. Wirth et al. (1999) compiled rooting depths of various plant species found on the NTS. The depth of rooting is closely tied to soil characteristics, a relationship that can advantageously be applied to the design of closure covers.

\subsubsection{Animal Burrowing}

Ants and termites are the most numerous burrowing insects on the NTS (O'Farrell and Emery, 1976). Both small and large burrowing mammals are present in the areas of the RWMSs.

Rodents are the most common of the mammalian species on the NTS (Allred et al., 1963). The depth of plant rooting is closely tied to soil characteristics. The depth of burrowing is closely tied to soil conditions and plant rooting depths (see Section 3.4.2).

\subsection{Geology}

Detailed descriptions of the geology of Yucca Flat and Frenchman Flat are in the PAs for the RWMSs in those areas (Shott et al., 1998, 1997;1995). 


\subsubsection{Regional Geology}

A sequence of rocks at the NTS composed of Proterozoic and Paleozoic, primarily marine, sedimentary rocks; locally intrusive Cretaceous granitic rocks; Miocene volcanic rocks; and post-volcanic sand and gravel would be approximately $10,500 \mathrm{~m}(35,000 \mathrm{ft})$ thick if stacked at one location according to age (Frizzell and Shulters, 1990). The geometry of these rocks is complex. The Proterozoic and Paleozoic rocks were significantly deformed in Late Mesozoic time (approximately 70 million years ago). At that time, older rocks were thrust eastward tens of kilometers (tens of miles) over younger rocks, in some places resulting in repetition of the sequence of rocks (Orkild, 1983). In mid-Tertiary (Miocene) to Quaternary time, the Proterozoic and Paleozoic rocks and the overlying Miocene volcanic rocks were deformed by large-scale extensional block faulting, which is largely responsible for the present Basin and Range topography in Nevada. The extensional faulting is thought to have occurred in two phases across the NTS. The initial phase, about 16 to 14 million years ago, consisted of high-angle northwest- and northeast-trending normal faults, and detachment faults (Cole et al., 1989). A second phase, younger than 11 million years ago, consisted of steeply dipping north-to-south-trending normal faults. This later phase is responsible for the basin-forming faults presently obvious in Yucca Flat (Dockery-Ander, 1984).

\subsubsection{Yucca Flat Geology}

The geologic structure of Yucca Flat is typical of intermontaine basins throughout the Basin and Range Province of Nevada and adjoining states. The surrounding mountain ranges consist primarily of Tertiary volcanic rocks and underlying Paleozoic sedimentary rocks (Figure 3.1). These ranges bound rotated and downdropped blocks in the basin. Erosion of the mountain ranges has resulted in deposition of a significant thickness of alluvium in the basin. The topography of the prealluvial surface and ongoing structural activity during deposition of the alluvium influence the present thickness of the alluvium. The thickness of alluvium in southern Yucca Flat ranges between 30 to over $914 \mathrm{~m}$ (100 to over 3,000 ft) (Drellack, 1994). At the Area 3 RWMS, alluvium is approximately $300 \mathrm{~m}(1,000 \mathrm{ft})$ thick. Extensive stratigraphic data have been collected from boreholes in Yucca Flat (Drellack and Thompson, 1990; Gonzales et al., 1998). Borehole U-3cn\#5 is the closest of the deep boreholes drilled in Yucca Flat to the

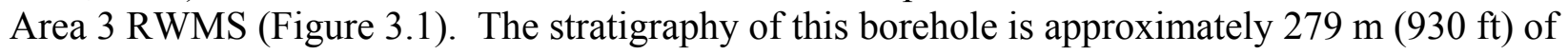

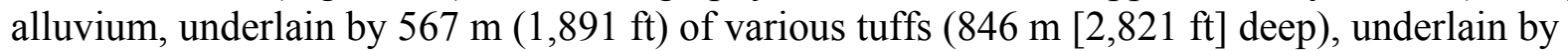

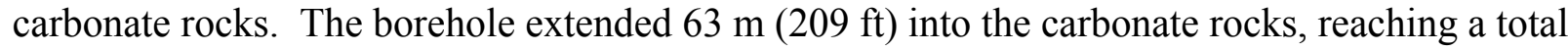
depth of $909 \mathrm{~m}(3,030 \mathrm{ft})$.

Principal faults in Yucca Flat are the Yucca Fault and the Carpetbag Fault (Figure 3.1). Both faults are east-dipping, moderately high-angle normal faults. The Yucca Fault trends north-south through the east-central part of the valley. The Carpetbag Fault trends north-south through the western part of the valley. Toward the south, the Carpetbag Fault steps eastward where it is called the Topgallant Fault. Knauss (1981) brackets the last natural movement along the Carpetbag fault between 93,000 and 37,000 years ago, and along the Yucca Fault at less than 35,000 years ago. Apparent movement on the faults may be due to localized differential compaction of the alluvium related to underground nuclear testing rather than movement along the entire vertical fault plane. 
The Area 3 RWMS is on a structural block bounded on the west by the Yucca Fault and on the east by a west-dipping fault known as the Area 3 Fault (Figure 3.1). The Area 3 Fault is a wishbone-shaped fault system in Area 3 and southern Area 7 (a north-south trace defined by nuclear-testing-induced fractures and a pretesting lineament at the north end, and a curved east branch defined by a pretesting lineament that was cracked along its entire length by nuclear testing). The east branch lineament is manifested as a scarp in three locations. The northernmost of the three scarps offsets a Late Pleistocene- or early Holocene-aged surface, providing a maximum age for the latest movement on that part of the fault. The nuclear-testing-induced fractures, which delineated most of the west branch of the Area 3 Fault, are no longer evident. The mapped trace of the west branch of the Area 3 Fault crosses the eastern side of the Area 3 RWMS. Continuity of beds exposed in a trench dug across the trace of the fault within the RWMS shows no major vertical displacement since at least early Holocene time (7,000 to 10,000 years), and probably since the Middle Pleistocene (several hundreds of thousands of years). Minor vertical fractures with minimal extent were present. The lack of major displacement within this time frame suggests that disposal operations and closure covers will not be impacted by the Area 3 Fault within the foreseeable future (BN, 1998b).

\subsubsection{Frenchman Flat Geology}

The mountain ranges surrounding Frenchman Flat consist primarily of Tertiary volcanic rocks and underlying Paleozoic sedimentary rocks (Figure 3.2). These ranges bound rotated and downdropped blocks in the basin. Erosion of the mountain ranges has resulted in deposition of a significant thickness of alluvium. The stratigraphy of rocks within Frenchman Flat to intermediate depths is known to a reasonable degree based on boreholes drilled for water wells and underground nuclear testing. Alluvium in Frenchman Flat ranges between 0 and 1,500 $\mathrm{m}(0$ and 4,900 ft), based on recent drill hole and 3-D seismic reflection data; alluvium directly below the Area 5 RWMS is approximately $914 \mathrm{~m}(3,000 \mathrm{ft})$ thick $(\mathrm{BN}, 2005)$. Basalt flows with numerical ages of 8.6 and 8.4 million years are interbedded in the alluvium in the northern part of Frenchman Flat, approximately $270 \mathrm{~m}(900 \mathrm{ft})$ below the ground surface (Well ER-5-3 log [unpublished]). These flows tend to separate alluvium with a predominant percentage of Tertiary-aged tuff from underlying alluvium with a predominant percentage of Paleozoic-aged sediments (Snyder et al., 1994). This suggests that the source of alluvium in northern Frenchman Flat changed from being predominantly from the northeast to being predominantly from the north about 8.5 million years ago. The alluvium is underlain by interbedded Tertiary ash-flow and ash-fall tuff estimated to be over $1,190 \mathrm{~m}(3,900 \mathrm{ft})$ thick directly below the Area 5 RWMS. On the basis of 3-D seismic reflection data (BN, 2005), the upper surface of the underlying carbonate rocks is about $2,100 \mathrm{~m}(6,900 \mathrm{ft})$ below the surface at the Area $5 \mathrm{RWMS}$, and perhaps as deep as 2,740 $\mathrm{m}(9,000 \mathrm{ft})$ near the center of the basin. A well recently drilled in northern Frenchman Flat as part of the Underground Test Area (UGTA) Program showed the top of the carbonate rocks to be $1,426 \mathrm{~m}(4,678 \mathrm{ft})$ below surface approximately $3.2 \mathrm{~km}(2 \mathrm{mi})$ northeast of the RWMS.

Principal faults in Frenchman Flat are the Cane Spring Fault and the Rock Valley Fault (Figure 3.2). The Cane Spring Fault is a left-lateral, strike-slip fault that trends southwest to 
northeast in the northern part of Frenchman Flat, $6.4 \mathrm{~km}(4 \mathrm{mi})$ northwest of the RWMS. The Rock Valley Fault is a left-lateral, strike-slip fault with a minor dip-slip component (down to the north) that trends southwest to northeast in the southern part of Frenchman Flat, about $8.8 \mathrm{~km}$ $(5.5 \mathrm{mi})$ south of the RWMS. Both of these faults are active and responsible for earthquakes within the recent past (see Section 3.8.1).

\subsection{Hydrology}

\subsubsection{Surface Water}

No permanent surface water is present within Yucca Flat, with the exceptions of small artificial impoundments and five springs that issue from perched aquifers recharged from infiltration through fractures in the surrounding mountains. Most water that issues from these springs travels only a short distance before evaporating or infiltrating into the ground. Reitman Seep, located $6.4 \mathrm{~km}$ (4 mi) northeast of the Area $3 \mathrm{RWMS}$, is the closest spring to the site.

Alluvial fans within Yucca Flat are cut by numerous arroyos (dry washes) that drain storm runoff to the playa. Water that accumulates on the playa typically evaporates or infiltrates, or both, within days to several weeks, but sometimes persists more than one month. Yucca Playa is approximately $8 \mathrm{~km}(5 \mathrm{mi})$ south of the Area $3 \mathrm{RWMS}$.

No permanent surface water is present within Frenchman Flat, with the exception of small artificial impoundments and Cane Spring, which issues from a perched aquifer recharged from infiltration through fractures in the nearby mountains. Cane Spring is approximately $14.4 \mathrm{~km}$ (9 mi) southwest of the Area 5 RWMS. Alluvial fans within Frenchman Flat are cut by numerous arroyos that drain storm runoff to the playa. Water that accumulates on the playa typically evaporates or infiltrates, or both, within a short period of time. Frenchman Playa is approximately $6.4 \mathrm{~km}$ (4 mi) southeast of the Area 5 RWMS.

\subsubsection{Unsaturated Zone}

Climate and vegetation strongly control the movement of water in the upper $2 \mathrm{~m}(6 \mathrm{ft})$ of the alluvium (Figure 3.3). The magnitude and direction of both liquid and vapor fluxes vary seasonally and often daily. Except for periods following precipitation events, water contents in this near-surface region are low. Below the near-surface region is a region where relatively steady upward movement of water is occurring. In this region of slow upward water movement, stable isotope compositions of soil pore water show that evaporation is the dominant process (Tyler et al., 1996). This region extends to depths from approximately 3 to $49 \mathrm{~m} \mathrm{(10} \mathrm{to} 160 \mathrm{ft})$ in Area 3, and from approximately 3 to $40 \mathrm{~m}$ (10 to $130 \mathrm{ft})$ in Area 5. Below this region, water potential measurements indicate the existence of a static region, which begins between approximately 49 to $119 \mathrm{~m}(160$ and $390 \mathrm{ft})$ in Area 3, and between approximately 40 to $90 \mathrm{~m}$ (131 and $295 \mathrm{ft}$ ) in Area 5 (Shott et al., 1998, 1997, 1995). In this static region, essentially no vertical 


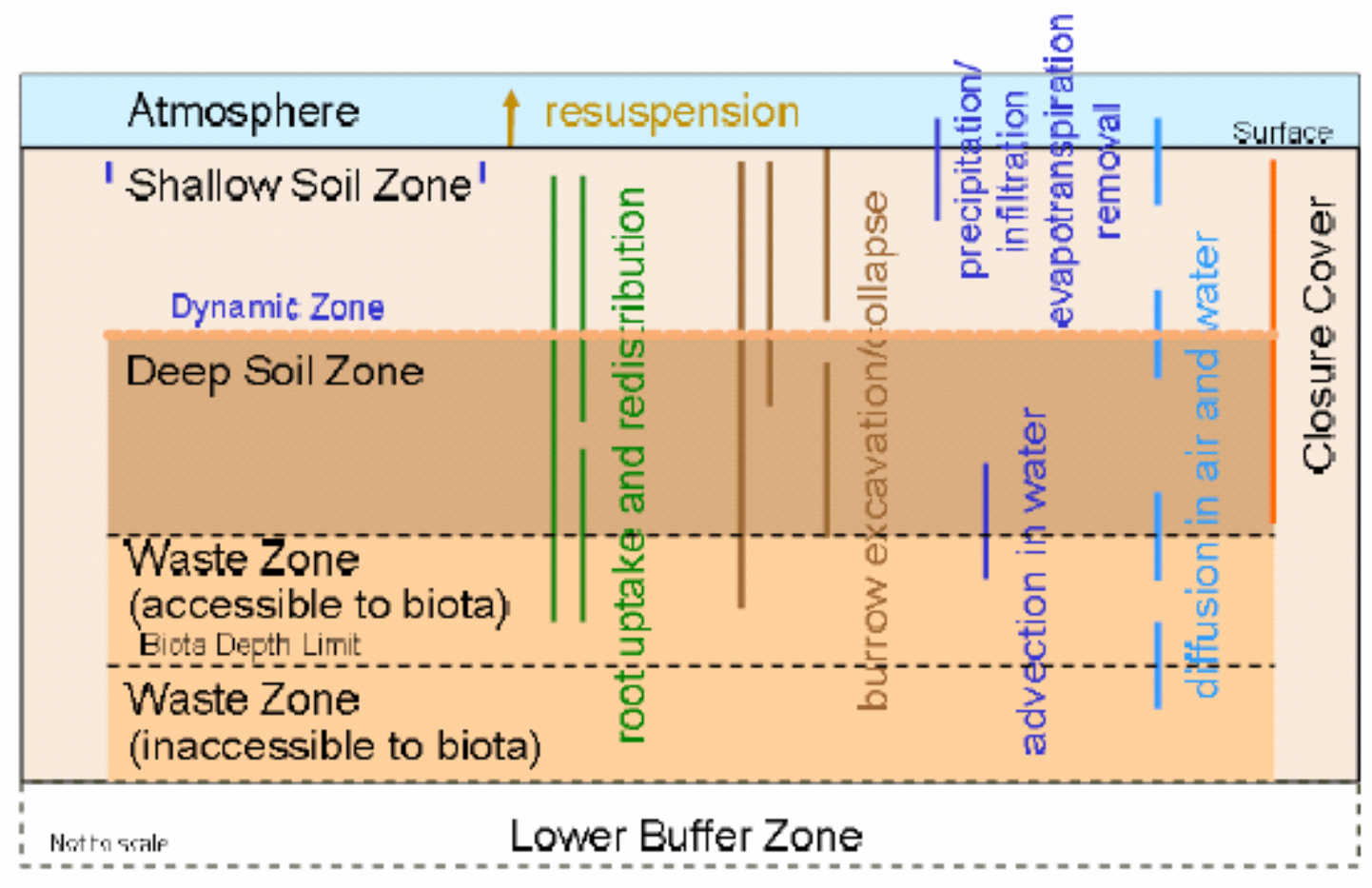

Figure 3.3 Conceptual model of near-surface processes in the unsaturated zone; in this case, an evapotranspiration closure cover over waste in shallow land burial (modified from Crowe, 2004)

liquid flow is currently occurring. Below this static region, flow is steady and downward due to gravity. A conceptual model of unsaturated zone processes is shown in Figure 3.4. Stable isotope compositions of pore water indicate that infiltration into the static region must have occurred under cooler, past climate conditions (Tyler et al., 1996). If contaminants were to migrate below the currently static region, movement to the groundwater would be extremely slow due to the low water content of the alluvium. Conservative estimates from beneath the static region to the groundwater in Area 5 are in excess of 50,000 years (Shott et al., 1995). Conservative estimates of travel times from just beneath the root zone to groundwater in Area 3 are in excess of 500,000 years, assuming zero upward flux (Levitt et al., 1998).

Based on the results of extensive research, field studies, modeling data, and monitoring data, which are summarized in the Area 3 and Area 5 RWMS PAs (Shott et al., 1998, 1997, 1995) and in Levitt et al. (1998), there is no areally distributed groundwater recharge under current climatic conditions at the RWMSs. Recent studies indicate that under bare-soil conditions such as those found at the operational waste unit covers, some drainage may occur through the covers into the waste zone. This drainage is estimated to be about 1 percent of the annual rainfall at Area 5, and 10 percent of annual rainfall at Area 3, based on conservative modeling results (Levitt et al., 1999). In addition, monitoring data from a bare-soil weighing lysimeter located in Area 5 


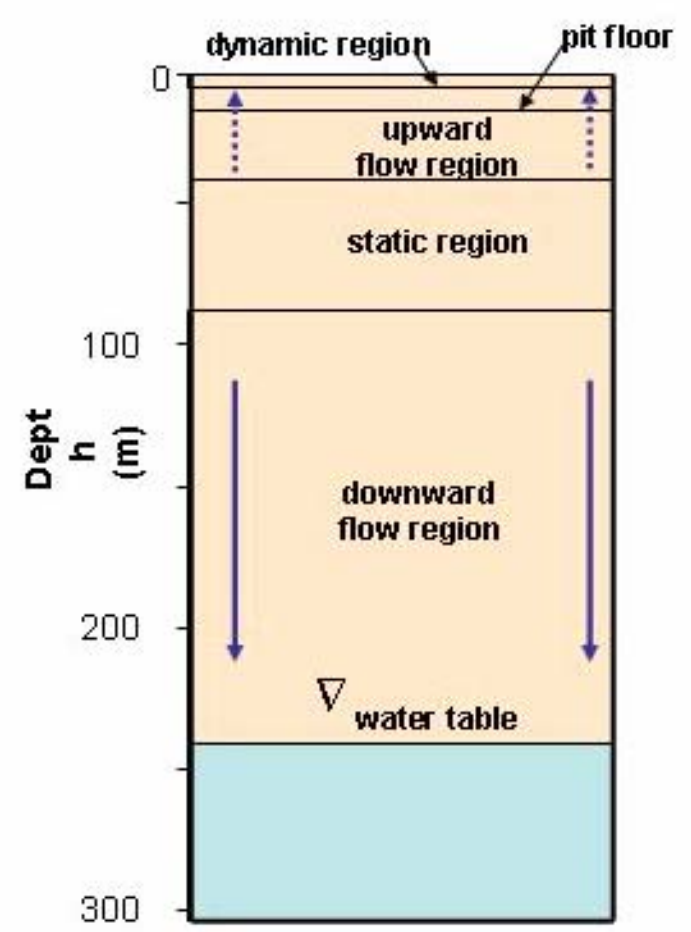

Dynamic Region: The magnitude and direction of liquid fluxes vary dependent on episodic infiltration, evapotranspiration, and biotic transport.

Upward Flow Region: The combination of low precipitation and high potential evapotranspiration leads to a dry zone inducing slow upward flow of pore water in the unsaturated zone from as deep as about $35 \mathrm{~m}$. Average upward velocity is about $0.02 \mathrm{~mm} / \mathrm{y}$.

The waste zone is in the region of upward flow.

Static Region: no vertical liquid movement (matric suction and gravitational forces balance). The thickness and the depth of this region change with the physicalitextural properties of alluvium and in situ water content.

\footnotetext{
Dowrward Flow Region: Steady downward flow is driven by gravity (increased water contents allow downward drainage). This extends from the static region to the capillary fringe directly above the water table.

Groundwater travel time: $>\mathbf{5 0 , 0 0 0}$ years (under current conditions)
}

Figure 3.4 Conceptual model of water-flow regions in the unsaturated zone in the vicinity of the Area 5 Radioactive Waste Management Site (modified from Crowe, 2004)

indicate that soil-water contents at depths of 1 to $2 \mathrm{~m}$ (3 to $7 \mathrm{ft})$ are slowly increasing. It is unclear if water contents are approaching equilibrium values or increasing until drainage occurs through the bottom of the lysimeter. Drainage through the waste covers should not be confused with groundwater recharge because the covers will ultimately become partially vegetated, eliminating the downward pathway. Deep drainage and potential groundwater recharge appear to be occurring primarily along mountain fronts, but also in isolated valley locations at the NTS where soil permeabilities are high and vegetation is sparse.

\subsubsection{Saturated Zone}

The NTS is located within the Death Valley Regional Flow System (DVRFS), one of the major hydrologic subdivisions of the southern Great Basin. The DVRFS covers an area of about $40,920 \mathrm{~km}^{2}\left(15,800 \mathrm{mi}^{2}\right)$. This regional flow system consists primarily of volcanic rock in the west and carbonate rock in the east and is estimated to transmit more than 8.6 million cubic meters $\left(\mathrm{m}^{3}\right)(70,000 \mathrm{ac}-\mathrm{ft})$ of groundwater annually. Most of this flow moves through a thick sequence of Paleozoic carbonate rock extending throughout the subsurface of central and southeastern Nevada and is sometimes referred to as the "central carbonate corridor." The division of the DVRFS into different groundwater flow systems within the NTS is based on the 
concept of a groundwater subbasin, defined as the area that contributes water to a major surface discharge. Three principal groundwater subbasins have been identified within the NTS region as the Ash Meadows, Oasis Valley, and Alkali Flat-Furnace Creek Ranch subbasins. Yucca Flat and Frenchman Flat lie within the Ash Meadows Subbasin (Laczniak et al., 1996).

The Ash Meadows subbasin covers an area of about $10,360 \mathrm{~km}^{2}\left(4,000 \mathrm{mi}^{2}\right)$. Precipitation is believed to recharge the subbasin along its northern boundary at the Belted, Reveille, Timpahute, and Pahranagat Ranges, along its eastern boundary at the Sheep Range, and along its southern boundary at the Spring Mountains. Recharge is also suspected to occur within the subbasin at higher elevations of the Spotted, Pintwater, and Desert Ranges. Groundwater primarily flows through the lower carbonate-rock aquifer and discharges along a line of springs in Ash Meadows. Groundwater flow rates through the different lithologic units of the Ash Meadows subbasin are highly variable. Estimates range from less than 0.3 to more than $300 \mathrm{~m} /$ day ( 1 to $1000 \mathrm{ft} / \mathrm{day}$ ), depending on the unit. In general, the regional carbonate-rock aquifer is believed to transmit water at the fastest rate, whereas the basement and Eleana confining units transmit water at the slowest rate, and volcanic and valley-fill aquifers and confining units transmit water at intermediate rates (Laczniak et al., 1996).

The lower carbonate-rock aquifer within the Ash Meadows subbasin is the only subsurface pathway by which groundwater leaves Yucca Flat and Frenchman Flat basins. Groundwater flows south from Yucca Flat into Frenchman Flat and then southwest toward downgradient areas (primarily Ash Meadows). Water levels within the lower carbonate-rock aquifer indicate that the gradient is nearly flat (less than $0.3 \mathrm{~m} / \mathrm{km}$ [1.6 ft/mi]) between Yucca Flat and Frenchman Flat and down to the discharge area at Ash Meadows. This flat gradient is an indication of a high degree of hydraulic continuity within the aquifer, which is probably a result of a high fracture (secondary) permeability (Laczniak et al., 1996).

Recent work for the UGTA project has enhanced the understanding of the hydrology of the NTS through the definition of hydrogeologic and hydrostratigraphic units (HGUs and HSUs) for use in modeling the geology and hydrology of the NTS area (Gonzales et al., 1998; Gonzales and Drellack, 1999). Many of these units are applicable to the Yucca basin, as described below.

All the rocks of the Yucca Flat study area can be classified as one of eight HGUs, which include the alluvial aquifer, four volcanic HGUs, one intrusive unit, and two HGUs that represent the pre-Tertiary rocks.

The strata in the Yucca Flat area have been subdivided into eleven Tertiary-age HSUs (including the Tertiary/Quaternary alluvium), one Mesozoic intrusive HSU, and six Paleozoic HSUs. The dominant HSUs in the former Yucca Flat testing area, in descending order, are: the alluvial aquifer (AA), the volcanic aquifers (including the Timber Mountain and Topopah Spring welded tuff aquifers [TM-WTA and TSA]), the lower tuff confining unit (LTCU), the regional carbonate aquifer (or lower carbonate aquifer [LCA]), and the lower clastic confining unit (LCCU). The area immediately north of Yucca Flat proper includes several additional welded tuff and lava 
flow aquifers (e.g., Tub Spring and Grouse Canyon welded tuff aquifers), and the Mesozoic granite intrusive confining unit. More information regarding HSUs in Yucca Flat can be found in Gonzales and Drellack (1999).

The static water level (SWL) in the Yucca Flat basin is relatively deep, ranging in depth from about $183 \mathrm{~m}(600 \mathrm{ft})$ in extreme western Yucca Flat to more than $580 \mathrm{~m}(1,900 \mathrm{ft})$ in northcentral Yucca Flat. The elevation of the water table in the Yucca Flat area varies from 1,340 m $(4,400 \mathrm{ft})$ above Mean Sea Level in the north (western Emigrant Valley) to $730 \mathrm{~m}(2,400 \mathrm{ft})$ at the southern end of Yucca Flat (Laczniak et al., 1996; Hale et al., 1995). Throughout much of the Yucca Flat area, the SWL typically is located within the lower portion of the volcanic section, in the Yucca Flat lower confining unit (YF-LCU). Beneath the hills surrounding Yucca Flat, the SWL can be within the Paleozoic units, whereas in the deeper structural subbasins of Yucca Flat, the Timber Mountain Tuff, and the lower portion of the alluvium are also saturated.

Fluid levels measured in wells completed in the alluvial aquifer and volcanic units in the eastern two-thirds of Yucca Flat are typically about $20 \mathrm{~m}$ (70 ft) higher than in wells completed in the regional carbonate aquifer (Winograd and Thordarson, 1975; IT, 1996a,b). The hydrogeology of these units suggests that the higher elevation of the water table in the overlying Tertiary rocks is related to the presence of low-permeability zeolitized tuffs of the tuff confining unit (aquitard) between the Paleozoic and Tertiary aquifers. Detailed water-level data indicate the existence of a groundwater trough along the axis of the valley. The "semi-perched" water within the alluvial aquifer and volcanic aquifers eventually moves downward to the carbonate aquifer in the central portion of the valley. Water-level elevations in western Yucca Flat are also well above the regional water level. The hydrology of western Yucca Flat is influenced by the presence of the Mississippian siliciclastic rocks, which directly underlie the carbonate aquifer of the upper plate of the CP thrust (locally present), alluvial aquifer, and volcanic rocks west of the Topgallant fault. This geometry is a contributing factor in the development of higher (semi-perched) water levels in this area. The Climax stock also bears perched water (Walker, 1962; Laczniak et al., 1996) well above the regional water level.

The present structural interpretation for Yucca Flat depicts the pre-Cambrian siliciclastic sedimentary rocks (also referred to as the LCCU) at great depth, except in the northeast corner of the area. The Zabriskie Quartzite and Wood Canyon Formation, which are both classified as clastic confining units, are exposed in the northern portion of the Halfpint Range. The high structural position of the LCCU there (and in combination with the Climax stock) may be responsible for the steep hydrologic gradient observed between western Emigrant Valley and Yucca Flat. Water-level data for the LCA in the southern part of the NTS are limited, but indicate a fairly low gradient in the Yucca Flat, Frenchman Flat, and Jackass Flats areas. This gentle gradient implies a high degree of hydraulic continuity within the aquifer, presumably due to high fracture permeability (Laczniak et al., 1996). Furthermore, the similarity of the water levels measured in Paleozoic rocks (LCA) in Yucca Flat and Frenchman Flat implies that, at least for deep interbasin flow, there is no groundwater barrier between the two basins. 
Based on the existing data and as interpreted from a regional groundwater flow model (DOE, 1997), the overall groundwater flow direction in the Yucca Flat and Frenchman Flat areas is to the south. Groundwater ultimately discharges at Ash Meadows and Franklin Lake Playa to the south and Death Valley to the southwest.

The hydrogeology of Frenchman Flat is complex, but is typical of the NTS area. The strata in the Frenchman Flat area have been subdivided into five Tertiary-age HSUs (including the Quaternary/Tertiary alluvium) and three pre-Tertiary HSUs to serve as layers for the UGTA Frenchman Flat CAU groundwater model (IT, 1998). In descending order these units are: the AA, the Timber Mountain aquifer (TMA), the Wahmonie confining unit (WCU), the tuff confining unit (TCU), the volcaniclastic confining unit (VCU), the LCA, and the LCCU. More recent information regarding HSUs in Frenchman Flat can be found in BN (2005).

The depth to the SWL in Frenchman Flat ranges from $210 \mathrm{~m}(690 \mathrm{ft})$ near the central playa to more than $350 \mathrm{~m}(1,150 \mathrm{ft})$ at the northern end of the valley. The SWL is generally located within the AA, TMA, WCU, or TCU. In the deeper, central portions of the basin, more than half of the alluvium section is saturated. Water-level elevation data in the AA indicate a very flat water table (IT, 1998).

Water-level data for the LCA in the southern part of the NTS are limited, but indicate a fairly low gradient in the Yucca Flat, Frenchman Flat, and Jackass Flats area. This gentle gradient implies a high degree of hydraulic continuity within the aquifer, presumably due to high fracture permeability (Laczniak et al., 1996). Furthermore, the similarity of the water levels measured in Paleozoic rocks (LCA) in Yucca Flat, Frenchman Flat, and Mercury Valley implies that, at least for deep interbasin flow, there is no groundwater barrier between the three basins. Inferred regional groundwater flow through Frenchman Flat is to the south, turning southwest in Mercury Valley toward discharge areas in Ash Meadows. An increasing westward flow vector in southern NTS may be due to preferential flow paths subparallel to the northeast-trending Rock Valley fault (Grauch and Hudson, 1995) and/or a northward gradient from the Spring Mountain recharge area (IT, 1996a,b).

\subsubsection{Groundwater Chemistry}

Three types of groundwater chemistry facies dominate the region: (I) a calcium-magnesium bicarbonate $\left(\mathrm{Ca}-\mathrm{Mg}-\mathrm{HCO}_{3}\right)$ facies within the carbonate units, (II) a sodium and potassium bicarbonate $\left(\mathrm{Na}-\mathrm{K}-\mathrm{HCO}_{3}\right)$ facies derived from groundwater in volcanic rocks, and (III) a mixed facies containing components from both (I) and (II). The Na-K-HCO 3 facies (II) is found within the lava-flow aquifer and tuff-aquitard units. The facies also is seen in portions of the valley-fill aquifer, where a major portion of the alluvial-fill material has been derived from the erosion of volcanic units. The $\mathrm{Ca}-\mathrm{Mg}-\mathrm{HCO}_{3}$ composition (I) is found within the Paleozoic carbonate units, such as the LCA and in the valley-fill aquifers that are composed of carbonate detritus. Most of the calcium and magnesium present is from the dissolution of limestone and dolomite $\left(\mathrm{CaCO}_{3}\right.$ and $\left.\mathrm{CaMg}\left[\mathrm{CO}_{3}\right]_{2}\right)$ mineralization in the unit as it conducts flow. Water of the mixed facies (III) contains portions of both the $\mathrm{Na}-\mathrm{K}$ and $\mathrm{Ca}-\mathrm{Mg}$ ions groups (Chapman, 1994; Winograd and Thordarson, 1975). 


\subsection{Soil Geochemistry}

The geochemistry of the native alluvium affects the transport of radionuclides by affecting their solubility and sorption characteristics. The alluvium is dominated by quartz, feldspar, and cristobalite, with calcite, gypsum, and minor amounts of clays and zeolites. Measured $\mathrm{pH}$ values range between 7 and 9, indicating neutral to alkaline conditions (Cochran et al., 2001). The presence of clays and zeolites in an alkaline environment generally inhibit the mobility of radionuclides. The geochemical environment of the closure cover is anticipated to be largely determined by the geochemistry of the constituent alluvium.

\subsection{Natural Hazards}

Natural hazards that may affect the LLW disposal areas in real-time include seismic activity and flooding. The hazard of volcanic activity has a sufficiently low probability to be discounted over the operational life and foreseeable future of the facility. While these natural hazards are unpredictable, studies have been done to determine the relative risk of these hazards impacting the disposal sites and all possible measures have been implemented to reduce the risk of containment failure.

\subsubsection{Seismicity}

Seismic hazard studies conducted at the NTS (Campbell, 1980; Battis, 1978; Rogers et al., 1977; and Hannon and McKague, 1975) agree that the predicted maximum Richter magnitude for an earthquake is between 5.8 and 7.0, with a peak acceleration between 0.7 and $0.9 \mathrm{~g}$. The predicted maximum magnitude earthquake (and the associated peak acceleration) has a return period between 12,700 and 15,000 years (Metcalf, 1983). The seismic studies show a 0.54 probability of an earthquake with a Richter magnitude greater than 6.8 within the next 10,000 years.

Earthquakes with magnitudes between 4.3 and 4.5 occurred in Frenchman Flat in 1971 and 1973 (Case et al., 1984) and in 1999 (see www.earthquake.usgs.gov; www.seismo.unr.edu). The 1973 and 1999 earthquakes were associated with the Rock Valley Fault, whereas the 1971 earthquake was associated with the Cane Spring Fault. The focus of this latter earthquake was in the Massachusetts Mountains which separate Yucca Flat and Frenchman Flat. No surface rupture was reported from any of these earthquakes. Because of the absence of layers that could be disrupted by movement, the monolayer-ET design anticipated for closure covers at both RWMSs is intrinsically not prone to significant damage from earthquakes.

\subsubsection{Volcanism}

The risk of volcanism in the NTS region is indicated by the potential for either future silicic or basaltic volcanism. Silicic volcanism is characterized by large-volume, explosive eruptions; whereas basaltic volcanism is characterized by cinder cones and lava flows of limited extent. The hazard for silicic volcanism is considered to be negligible because: 
- Since its peak (from 15 to 9 million years ago), there has been a significant decrease and, in most areas, a cessation of silicic volcanism within the central and southern parts of the Great Basin. The last major silicic events were the Black Mountain caldera which erupted 9.4 million years ago and the Stonewall Mountain caldera which erupted 7.6 million years ago;

- Silicic volcanism has been absent in the NTS region for the past 7.6 million years.

- Quaternary (less than 10,000 years) silicic volcanism is restricted to the eastern and western margins of the Great Basin (Crowe et al., 1983). A transition from predominantly silicic volcanism to basaltic volcanism occurred approximately 10 million years ago.

Late- and post-Miocene basaltic volcanism in the NTS region is divided into two episodes: (1) large-volume basaltic centers that are spatially and temporally associated with the waning phase of silicic volcanism; and (2) small-volume, spatially scattered basalt centers that postdate silicic volcanism (Crowe, 1990). The latter episode of volcanism is subdivided into two cycles: late Miocene basalt centers in the east and north-center of the NTS, and Pliocene and Quaternary basalt centers primarily in the southwest part of the NTS region. The youngest basaltic volcanic center in the NTS region is the 70,000-year-old basalt of Lathrop Wells. The youngest basalt within Yucca Flat, at 8.4 million years, is between 226 and $308 \mathrm{~m}$ (740 and 1,010 ft) deep in borehole UE-1h, $1.6 \mathrm{~km}(1 \mathrm{mi})$ southwest of the Area $3 \mathrm{RWMS}$. The youngest basalt within Frenchman Flat, at 7.4 million years, is exposed at the surface in Nye Canyon, approximately $21 \mathrm{~km}(13 \mathrm{mi})$ northeast of the Area 5 RWMS.

The greatest hazard of future basaltic volcanism in the NTS region is within zones of Pliocene and Quaternary volcanism (Crowe et al., 1998a). The Area 3 and Area 5 RWMSs are outside and a considerable distance from all Pliocene and Quaternary volcanic zones. Based on studies at Yucca Mountain, Crowe et al. (1998a) calculated the probability of magmatic disruption of an equivalent area outside a volcanic zone to be $3 \mathrm{E}-09$, or $3 \mathrm{E}-06$ over a 1,000-year compliance period. This probability is sufficiently low that basaltic volcanism can be dismissed as a credible event for the RWMSs.

\subsubsection{Flooding}

A flood hazard assessment for the Area 3 RWMS considered the entire watershed of Yucca Flat, but focused on a $94-\mathrm{km}^{2}\left(36-\mathrm{mi}^{2}\right)$ drainage area east of the Area 3 RWMS that has the greatest potential to impact the site. The assessment determined that the Area 3 RWMS is not within a Federal Emergency Management Agency (FEMA)-designated 100-year, 6-hour flood hazard zone (Miller, 1996).

Schmeltzer et al. (1993) identified three watersheds that could contribute water to the Area 5 RWMS: Barren Wash, Massachusetts Mountains - Halfpint Range, and Scarp Canyon. The total area of these watersheds is approximately $360 \mathrm{~km}^{2}\left(140 \mathrm{mi}^{2}\right)$. A flood hazard assessment for the Area 5 RWMS based on these watersheds shows that only the southwest corner of the Area 5 RWMS is within a 100 -year flood hazard zone. This zone is defined by FEMA to have a 
0.01 (1 percent) probability that a flood with a depth of flow greater than $0.3 \mathrm{~m}(1 \mathrm{ft})$ could occur within any given year. The southwest corner of the RWMS has the potential for flooding from both alluvial-fan flow on the Barren Wash fan and shallow concentrated flow on the Massachusetts Mountains - Halfpint Range fan. Other parts of the Area 5 RWMS are within an area referred to as Zone X, where sheetflow resulting from a 100-year, 6-hour precipitation event is anticipated to be less than $0.3 \mathrm{~m}(1 \mathrm{ft})$ deep. Recent studies, and a documented 25 -year, 24-hour precipitation event at the NTS, suggest that actual depths of flow and flow velocities may be considerably less than modeled because of water lost into the ground during transmission (French and Curtis, 1999). The currently active part of the Area 5 RWMS is now protected from a 25-year, 24-hour flood event via a channel and dike system.

\subsection{Natural Resources}

Exploration and exploitation of natural resources near the RWMSs potentially could have an impact on closure and monitoring over both the near and long terms. A natural resource is economically viable if it is available in sufficient quality and quantity, and a demand for the resource exists. Four potentially viable resources are identified for the NTS: sand and gravel, minerals, hydrocarbons, and water.

Both the Area 3 and Area 5 RWMSs are located on alluvial fans composed primarily of sand and gravel. Most sand and gravel is used for road base, building pads, and other fill structures. Construction of closure covers may require a relatively large volume of sand and gravel, presumably derived from within or near the RWMSs. Exploitation of sand and gravel from near the RWMSs for other than local use is unlikely because the gravels are composed largely of silicic volcanic rocks, which tend not to be durable. Additionally, good-quality sand and gravel are generally available elsewhere.

Four mining districts are present on the NTS: Calico Hills, Oak Spring, Mine Mountain, and Wahmonie. Of these four districts, Calico Hills is considered to be sufficiently distant from Yucca Flat and Frenchman Flat to not significantly impact the RWMS if the district should be developed. Oak Spring district is in northern Yucca Flat, Mine Mountain district is in southwestern Yucca Flat, and Wahmonie district is in Jackass Flats. The Oak Spring district is considered to have moderate potential for tungsten, and silver may be present (SAIC/DRI, 1991). Although economic deposits of silver and gold were extracted from Mine Mountain and Wahmonie districts, the current economic potential for these districts is uncertain (RichardHaggard, 1983; Gustafson et al., 1993). Overall, especially considering that DOE anticipates institutional controls over the NTS for the foreseeable future, the probability of mineral exploration and exploitation that would impact the RWMSs is low.

The potential for oil and natural gas in southern Nye County is thought to be low (Garside et al., 1988; Castor et al., 1990). Trexler et al. (1996), however, suggest a "cautiously optimistic view of the hydrocarbon potential" for the NTS and surrounding area based on the occurrence of thrust plates that provide potential reservoir space, and a favorable thermal history. Studies in southern Nye County and the NTS do not indicate the presence of coal, tar sand, or oil shale (Gustafson et al., 1993). 
Groundwater under the NTS is generally acceptable for drinking water, and industrial and agricultural uses (Chapman, 1994). Industrial and agricultural uses are currently precluded because of land use and institutional controls over the NTS into the foreseeable future. Human consumption of water has the greatest probability for impacting the RWMSs. Such impact is likely not to occur in the near term because (1) current demand is low, (2) the cost of extracting water from below Yucca Flat and Frenchman Flat is high, and (3) water is available from other sources. 
This Page Intentionally Left Blank 


\subsection{AREA 3 RADIOACTIVE WASTE MANAGEMENT SITE DESCRIPTION}

The facilities, operations, and inventory of wastes at the Area 3 RWMS are discussed in the following sections.

\subsection{Historical Development and Use}

The first documented disposal at the Area 3 RWMS was in U-3ax crater on July 30, 1968 (REECo, 1968); debris and soil contaminated by nuclear-device tests in the 1950s and early 1960s were collected and placed in the bottom of the crater (REECo, 1980) ${ }^{3}$. In 1984, when the bottom of U-3ax crater was level with the bottom of adjacent U-3bl crater, the area between the craters was excavated and disposal of contaminated debris and soil continued in the enlarged disposal unit. In 1985, cargo containers were disposed in the excavated area between the two craters and, in 1987, various sized containers were disposed in the upper part of U-3bl. An operational cover, nominally about $1.5 \mathrm{~m}$ (5 ft) thick (BN, 1999), was placed over U-3ax/bl after disposal operations stopped in 1987. A final closure cover was placed over U-3ax/bl in 2001. About 80 percent of the waste disposed in U-3ax/bl is contaminated debris and soil, and about half of this waste is soil. Low-level mixed waste was also disposed in U-3ax/bl (Elletson and Johnejack, 1995). Consequently, U-3ax/bl is regulated as a mixed-waste landfill under RCRA and was closed according to RCRA and DOE requirements.

Disposal of contaminated debris and soil from continued cleanup of atmospheric nuclear test areas was moved to U-3at crater in 1988. Two tiers of unpackaged waste were placed in the crater over a period of approximately one year. As at U-3ax/bl, the area between crater U-3at and adjacent crater U-3ah was then excavated to expand the volume for waste disposal. The resulting waste disposal unit is designated U-3ah/at. From 1989 to present, four additional tiers of waste in cargo containers, primarily from off-site generators, have been disposed in U-3ah/at. Soft-sided packages of plutonium-contaminated soil from cleanup of safety shots at the Tonopah Test Range north of the NTS have also been disposed in U-3ah/at since 1997. The disposal unit has sufficient remaining volume for at most one tier of waste, depending on the configuration of the final closure cover.

Unpackaged bulk waste and plutonium-contaminated soil and other waste in soft-sided packages and have been disposed in disposal cell U-3bh since 1997. Disposal is expected to continue until the cell is full. Disposed waste soil is covered with uncontaminated soil to ensure that contamination is not inadvertently spread.

\footnotetext{
${ }^{3}$ The Area 3 RWMS was formally established in 1978 with the advent of the NTS Waste Management Program.
} 


\subsection{Disposal Operations}

Waste to be disposed at the Area 3 RWMS is transported there on trucks. Upon arrival, manifests are checked and trucks are inspected both visually and with instrumentation to ensure that there is no leakage of contaminated materials from the containers. When cleared, the containers are off-loaded and placed in the appropriate area of the disposal unit, depending on whether the waste is in cargo containers, soft-sided packages, or is unpackaged. The location of the waste in the unit is recorded and tracked.

\subsection{Ancillary Facilities}

The only structures at the Area 3 RWMS are an office trailer and a change trailer that are manned only during disposal operations. All other functions are supported by facilities at the Area 5 RWMS.

\subsection{Waste Characteristics}

Radiological waste from the DOE Complex is accepted at the NTS for disposal. Discussion below describes the containers, any treatment or processing prior to disposal, and the inventory of wastes.

\subsubsection{Waste Containers}

Waste is generally delivered to the Area 3 RWMS in cargo containers, metal boxes that measure approximately $6 \mathrm{~m}(20 \mathrm{ft})$ long, $2.4 \mathrm{~m}(8 \mathrm{ft})$ wide, and $2.4 \mathrm{~m}(8 \mathrm{ft})$ high; one end of the container has doors that swing outward for access, or are loaded from the top. These containers are offloaded and disposed without opening. Waste is also delivered to the RWMS in soft-sided packages. These containers are also off-loaded and disposed without opening.

\subsubsection{Treatment or Processing Prior to Disposal}

Treatment or processing of waste is conducted by the waste generator prior to shipment to the RWMS for disposal. Generators desiring to ship waste to the NTS must have their waste certification program and waste stream(s) approved by NNSA/NSO. A waste stream is described on a waste profile. In addition to a description of the waste, a waste profile includes a description of the waste generation process(es), and an estimate of the low and high activity concentration of significant radionuclides. Approval to ship is granted on a waste-streamspecific basis once a generator's certification program has been approved. Waste shipped to the NTS for disposal must meet the NTSWAC (NNSA/NSO, 2003). Information on characterization of radiological waste is reported to the site operator, generally electronically, for entry into the site inventory at the time of shipment. 


\subsubsection{Waste Inventory}

The estimated closure inventory for disposal units U-3ah/at and U-3bh is presented in Table 4.1. The inventory was estimated by summing past disposals through FY 2003 and estimated future disposals. Future disposals were estimated by projecting past disposals into the future. Disposal was assumed to continue until FY 2013 when U-3ah/at and U-3bh were projected to be filled. The inventory applicable to the CA has not changed and is presented in Shott et al. (1997).

\subsection{Performance Assessment and Composite Analysis}

DOE M 435.1-1 Chapter IV, P (2) and (3) requires a site-specific radiological PA and CA to be prepared and maintained, respectively. Performance Assessments include only waste disposed after September 26, 1988, whereas CAs include all sources of radioactive material at the site that may interact with the low-level disposal facility. The PAs and CAs evaluate potential dose to a hypothetical member of the public during the compliance period specified in DOE Orders and associated guidance. At the time of preparation of the Area 5 PA, the compliance period was 10,000 years. The Area $3 \mathrm{PA} / \mathrm{CA}$ and Area $5 \mathrm{CA}$ were prepared after 1996 when the regulatory compliance period was reduced to 1,000 years.

A facility's PA and CA are reviewed by DOE/HQ for compliance with the performance objectives as listed in Section 4.5.1. If the performance objectives are met and review of the PA/CA maintenance plan, as well as preliminary closure and monitoring plans are deemed satisfactory, a DAS is issued. The DAS is a required part of the radioactive waste management basis for a disposal facility and specifies the limits and conditions on construction, design, operations, and closure of the low-level facility.

\subsubsection{Performance Objectives}

DOE M 435.1-1 Chapter IV, P (1) provides performance objectives for waste disposed in lowlevel waste disposal facilities after September 26, 1988, as:

(a) Dose to representative members of the public shall not exceed 25 mrem $(0.25 \mathrm{mSv})$ in a year total effective dose equivalent from all exposure pathways, excluding the dose from radon and its progeny in air.

(b) Dose to representative members of the public via the air pathway shall not exceed $10 \mathrm{mrem}(0.10 \mathrm{mSv})$ in a year total effective dose equivalent, excluding the dose from radon and its progeny.

(c) Release of radon shall be less than an average flux of $20 \mathrm{pCi} / \mathrm{m}^{2} / \mathrm{s}$ $\left(0.74 \mathrm{~Bq} / \mathrm{m}^{2} / \mathrm{s}\right)$ at the surface of the disposal facility. 
Table 4.1 Area 3 RWMS PA Estimated Inventory (Shott et al., 1997)

\begin{tabular}{|c|c|c|c|}
\hline Nuclide & $\begin{array}{l}\text { Geometric } \\
\text { Mean (Ci) } \\
\end{array}$ & $\begin{array}{c}\text { Geometric } \\
\text { Mean } \\
\left(\mathbf{C i} / \mathbf{m}^{3}\right) \\
\end{array}$ & $\begin{array}{c}\text { Geometric } \\
\text { Standard } \\
\text { Deviation } \\
\end{array}$ \\
\hline H-3 & $1.4 \mathrm{E}+05$ & $3.0 \mathrm{E}-01$ & $2.3 \mathrm{E}+00$ \\
\hline C-14 & $3.1 \mathrm{E}+00$ & $7.0 \mathrm{E}-06$ & $2.0 \mathrm{E}+00$ \\
\hline Al-26 & $2.1 \mathrm{E}-07$ & $4.7 \mathrm{E}-13$ & $4.4 \mathrm{E}+00$ \\
\hline $\mathrm{Cl}-36$ & $3.8 \mathrm{E}-03$ & 8.4E-09 & $2.8 \mathrm{E}+00$ \\
\hline Ar-39 & $1.2 \mathrm{E}-02$ & $2.7 \mathrm{E}-08$ & $3.3 \mathrm{E}+00$ \\
\hline Ar-42 & $3.5 \mathrm{E}-02$ & 7.7E-08 & $2.4 \mathrm{E}+00$ \\
\hline $\mathrm{K}-40$ & $4.4 \mathrm{E}-03$ & $9.7 \mathrm{E}-09$ & $2.9 \mathrm{E}+00$ \\
\hline $\mathrm{Ca}-41$ & $1.5 \mathrm{E}-02$ & $3.3 \mathrm{E}-08$ & $3.7 \mathrm{E}+00$ \\
\hline Ti-44 & $8.2 \mathrm{E}-01$ & $1.8 \mathrm{E}-06$ & $2.3 \mathrm{E}+00$ \\
\hline $\mathrm{Ni}-59$ & $4.3 \mathrm{E}-04$ & $9.5 \mathrm{E}-10$ & $3.4 \mathrm{E}+00$ \\
\hline $\mathrm{Ni}-63$ & $8.5 \mathrm{E}+00$ & $1.9 \mathrm{E}-05$ & $2.6 \mathrm{E}+00$ \\
\hline Co-60 & $6.2 \mathrm{E}-01$ & $1.4 \mathrm{E}-06$ & $2.5 \mathrm{E}+00$ \\
\hline Se-79 & $4.0 \mathrm{E}-05$ & 8.9E-11 & $3.1 \mathrm{E}+00$ \\
\hline $\mathrm{Kr}-85$ & 8.3E-01 & $1.8 \mathrm{E}-06$ & $3.4 \mathrm{E}+00$ \\
\hline Sr-90 & $1.0 \mathrm{E}+02$ & $2.2 \mathrm{E}-04$ & $2.2 \mathrm{E}+00$ \\
\hline Zr-93 & $7.2 \mathrm{E}-04$ & $1.6 \mathrm{E}-09$ & $3.0 \mathrm{E}+00$ \\
\hline $\mathrm{Nb}-93 \mathrm{~m}$ & $1.7 \mathrm{E}-02$ & $3.8 \mathrm{E}-08$ & $3.0 \mathrm{E}+00$ \\
\hline $\mathrm{Nb}-94$ & $1.4 \mathrm{E}-02$ & $3.1 \mathrm{E}-08$ & $2.5 \mathrm{E}+00$ \\
\hline Tc-99 & $5.8 \mathrm{E}+01$ & $1.3 \mathrm{E}-04$ & $2.1 \mathrm{E}+00$ \\
\hline Pd-107 & $2.4 \mathrm{E}-05$ & $5.3 \mathrm{E}-11$ & $3.0 \mathrm{E}+00$ \\
\hline Cd-113m & 8.0E-01 & $1.8 \mathrm{E}-06$ & $3.6 \mathrm{E}+00$ \\
\hline $\mathrm{Sn}-121 \mathrm{~m}$ & $5.0 \mathrm{E}-02$ & $1.1 \mathrm{E}-07$ & $3.3 \mathrm{E}+00$ \\
\hline Sn-126 & 7.1E-04 & $1.6 \mathrm{E}-09$ & $3.3 \mathrm{E}+00$ \\
\hline I-129 & $4.2 \mathrm{E}-03$ & $9.4 \mathrm{E}-09$ & $3.0 \mathrm{E}+00$ \\
\hline Cs-135 & $5.4 \mathrm{E}-04$ & $1.2 \mathrm{E}-09$ & $3.1 \mathrm{E}+00$ \\
\hline Cs-137 & $6.0 \mathrm{E}+03$ & $1.3 \mathrm{E}-02$ & $2.2 \mathrm{E}+00$ \\
\hline Ba-133 & $5.3 \mathrm{E}-01$ & $1.2 \mathrm{E}-06$ & $2.3 \mathrm{E}+00$ \\
\hline Sm-151 & $7.8 \mathrm{E}-01$ & $1.7 \mathrm{E}-06$ & $3.1 \mathrm{E}+00$ \\
\hline Eu-150 & $2.2 \mathrm{E}-03$ & 4.9E-09 & $3.9 \mathrm{E}+00$ \\
\hline Eu-152 & 9.3E-01 & $2.1 \mathrm{E}-06$ & $2.5 \mathrm{E}+00$ \\
\hline Eu-154 & $1.9 \mathrm{E}-01$ & $4.3 \mathrm{E}-07$ & $3.4 \mathrm{E}+00$ \\
\hline Gd-152 & $2.2 \mathrm{E}-14$ & $4.9 \mathrm{E}-20$ & $2.2 \mathrm{E}+00$ \\
\hline Но-166m & $6.4 \mathrm{E}-08$ & $1.4 \mathrm{E}-13$ & $2.8 \mathrm{E}+00$ \\
\hline $\mathrm{Pb}-210$ & $3.6 \mathrm{E}+00$ & $8.0 \mathrm{E}-06$ & $2.9 \mathrm{E}+00$ \\
\hline $\mathrm{Bi} 210 \mathrm{~m}$ & $5.9 \mathrm{E}-05$ & $1.3 \mathrm{E}-10$ & $2.7 \mathrm{E}+00$ \\
\hline Ra-226 & $5.5 \mathrm{E}-01$ & $1.2 \mathrm{E}-06$ & $3.0 \mathrm{E}+00$ \\
\hline $\mathrm{Ra}-228$ & $4.4 \mathrm{E}+00$ & $9.7 \mathrm{E}-06$ & $2.5 \mathrm{E}+00$ \\
\hline Ac- 227 & $2.0 \mathrm{E}-01$ & $4.4 \mathrm{E}-07$ & $3.3 \mathrm{E}+00$ \\
\hline Th-228 & $5.6 \mathrm{E}+00$ & $1.2 \mathrm{E}-05$ & $2.1 \mathrm{E}+00$ \\
\hline Th-229 & $1.1 \mathrm{E}-03$ & 2.4E-09 & $2.2 \mathrm{E}+00$ \\
\hline Th-230 & $5.3 \mathrm{E}+00$ & $1.2 \mathrm{E}-05$ & $2.1 \mathrm{E}+00$ \\
\hline Th-232 & $6.3 E+00$ & $1.4 \mathrm{E}-05$ & $2.5 \mathrm{E}+00$ \\
\hline $\mathrm{Pa}-231$ & $2.0 \mathrm{E}-03$ & $4.4 \mathrm{E}-09$ & $1.9 \mathrm{E}+00$ \\
\hline
\end{tabular}


Table 4.1 (continued)

\begin{tabular}{|c|c|c|c|}
\hline Nuclide & $\begin{array}{l}\text { Geometric } \\
\text { Mean (Ci) }\end{array}$ & $\begin{array}{c}\text { Geometric } \\
\text { Mean } \\
\left(\mathrm{Ci} / \mathrm{m}^{3}\right)\end{array}$ & $\begin{array}{c}\text { Geometric } \\
\text { Standard } \\
\text { Deviation }\end{array}$ \\
\hline U-232 & $1.3 \mathrm{E}+00$ & $2.8 \mathrm{E}-06$ & $2.7 \mathrm{E}+00$ \\
\hline U-233 & $1.0 \mathrm{E}+00$ & $2.3 \mathrm{E}-06$ & $2.3 \mathrm{E}+00$ \\
\hline U-234 & $2.2 \mathrm{E}+02$ & 4.8E-04 & $2.0 \mathrm{E}+00$ \\
\hline U-235 & $8.5 \mathrm{E}+00$ & $1.9 \mathrm{E}-05$ & $2.0 \mathrm{E}+00$ \\
\hline U-236 & $9.1 \mathrm{E}+00$ & $2.0 \mathrm{E}-05$ & $2.5 \mathrm{E}+00$ \\
\hline U-238 & $2.8 \mathrm{E}+02$ & $6.3 \mathrm{E}-04$ & $2.0 \mathrm{E}+00$ \\
\hline $\mathrm{Np}-237$ & $2.5 \mathrm{E}-01$ & $5.6 \mathrm{E}-07$ & $2.1 \mathrm{E}+00$ \\
\hline $\mathrm{Pu}-236$ & $4.7 \mathrm{E}-07$ & $1.0 \mathrm{E}-12$ & $3.6 \mathrm{E}+00$ \\
\hline $\mathrm{Pu}-238$ & $2.8 \mathrm{E}+00$ & $6.3 \mathrm{E}-06$ & $2.0 \mathrm{E}+00$ \\
\hline $\mathrm{Pu}-239$ & $6.7 \mathrm{E}+01$ & $1.5 \mathrm{E}-04$ & $2.2 \mathrm{E}+00$ \\
\hline $\mathrm{Pu}-240$ & $1.3 \mathrm{E}+01$ & $2.9 \mathrm{E}-05$ & $2.2 \mathrm{E}+00$ \\
\hline $\mathrm{Pu}-241$ & $4.8 \mathrm{E}+01$ & $1.1 \mathrm{E}-04$ & $2.3 \mathrm{E}+00$ \\
\hline $\mathrm{Pu}-242$ & $1.5 \mathrm{E}-03$ & $3.2 \mathrm{E}-09$ & $2.8 \mathrm{E}+00$ \\
\hline $\mathrm{Pu}-244$ & $1.9 \mathrm{E}-11$ & 4.3E-17 & $2.7 \mathrm{E}+00$ \\
\hline Am-241 & $1.1 \mathrm{E}+01$ & $2.4 \mathrm{E}-05$ & $2.2 \mathrm{E}+00$ \\
\hline Am-242m & $9.6 \mathrm{E}-03$ & $2.1 \mathrm{E}-08$ & $3.1 \mathrm{E}+00$ \\
\hline Am-243 & $4.3 \mathrm{E}-03$ & 9.6E-09 & $2.3 \mathrm{E}+00$ \\
\hline $\mathrm{Cm}-242$ & $7.8 \mathrm{E}-03$ & $1.7 \mathrm{E}-08$ & $3.1 \mathrm{E}+00$ \\
\hline $\mathrm{Cm}-243$ & $6.8 \mathrm{E}-05$ & $1.5 \mathrm{E}-10$ & $3.1 \mathrm{E}+00$ \\
\hline $\mathrm{Cm}-244$ & $3.9 \mathrm{E}-01$ & 8.6E-07 & $2.4 \mathrm{E}+00$ \\
\hline $\mathrm{Cm}-245$ & $2.2 \mathrm{E}-03$ & $4.9 \mathrm{E}-09$ & $2.3 \mathrm{E}+00$ \\
\hline $\mathrm{Cm}-246$ & $3.6 \mathrm{E}-04$ & 8.1E-10 & $2.3 \mathrm{E}+00$ \\
\hline $\mathrm{Cm}-247$ & $1.2 \mathrm{E}-13$ & 2.7E-19 & $2.9 \mathrm{E}+00$ \\
\hline $\mathrm{Cm}-248$ & $1.5 \mathrm{E}-22$ & $3.4 \mathrm{E}-28$ & $2.7 \mathrm{E}+00$ \\
\hline Cf-249 & $1.7 \mathrm{E}-07$ & $3.9 \mathrm{E}-13$ & $2.6 \mathrm{E}+00$ \\
\hline Cf-250 & $5.8 \mathrm{E}-08$ & $1.3 \mathrm{E}-13$ & $2.7 \mathrm{E}+00$ \\
\hline Cf- 251 & $3.2 \mathrm{E}-07$ & $7.0 \mathrm{E}-13$ & $3.0 \mathrm{E}+00$ \\
\hline Total & $1.4 \mathrm{E}+05$ & $3.2 \mathrm{E}-01$ & \\
\hline
\end{tabular}

The CA dose limit objective is $100 \mathrm{mrem} / \mathrm{yr}$ to a member of the public with a dose constraint of $30 \mathrm{mrem} / \mathrm{yr}$. Performance objectives and results of the Area 3 and Area 5 RWMS PAs are shown in Table 4.2.

\subsubsection{Status of Performance Assessment and Composite Analysis}

Upon review of the Area 3 PA/CA (Shott et al., 1997), DOE/HQ issued the DAS for the Area 3 RWMS on October 20, 1999, with conditions. The DAS for the Area 3 RWMS identified six secondary PA issues, one primary and one secondary CA issue, and requested that NNSA/NSO resolve the specified issues and revise the PA and CA accordingly. The revised PA and CA document was submitted to DOE/HQ for review in FY 2001. On July 25, 2001, 
Table 4.2 Performance objectives and results of the Area 3 and Area 5 RWMS Performance Assessments

MEMBER OF PUBLIC

\begin{tabular}{|c|c|c|c|}
\hline $\begin{array}{l}\text { Performance } \\
\text { Objective }\end{array}$ & $\begin{array}{c}\text { Area } 3 \text { RWMS } \\
\text { (Base Case) } \\
\text { 1,000-year (yr) analysis; } \\
\text { maximum values unless } \\
\text { specified otherwise }\end{array}$ & $\begin{array}{c}\text { Area } 5 \text { RWMS } \\
\text { (Base Case); } 10,000-y r \\
\text { analysis; maximum } \\
\text { values unless specified } \\
\text { otherwise }\end{array}$ & $\begin{array}{c}\text { Area } 5 \text { RWMS } \\
\text { (Subsided Case); } \\
\text { 10,000-yr analysis; } \\
\text { maximum values unless } \\
\text { specified otherwise }\end{array}$ \\
\hline $25 \mathrm{mrem} / \mathrm{yr}$, all paths & $\begin{array}{l}0.0009 \mathrm{mrem} / \mathrm{yr} ; \\
0.00004 \mathrm{mrem} / \mathrm{yr} \text { (mean) }\end{array}$ & $0.6 \mathrm{mrem} / \mathrm{yr}$ & $0.8 \mathrm{mrem} / \mathrm{yr}$ \\
\hline $\begin{array}{l}10 \mathrm{mrem} / \mathrm{yr} \text {, airborne } \\
\text { emissions excluding } \\
\text { radon }\end{array}$ & $\begin{array}{l}0.0004 \mathrm{mrem} / \mathrm{yr} ; \\
0.00003 \mathrm{mrem} / \mathrm{yr} \text { (mean) }\end{array}$ & $0.2 \mathrm{mrem} / \mathrm{yr}$ & $0.2 \mathrm{mrem} / \mathrm{yr}$ \\
\hline $\begin{array}{l}\text { Average annual }{ }^{222} \mathrm{Ra} \\
\text { flux }<20 \mathrm{pCi} / \mathrm{m}^{2} / \mathrm{s}\end{array}$ & $\begin{array}{l}0.1 \mathrm{pCi} / \mathrm{m}^{2} / \mathrm{s} \\
0.02 \mathrm{pCi} / \mathrm{m}^{2} / \mathrm{s} \text { (mean) }\end{array}$ & $6 \mathrm{pCi} / \mathrm{m}^{2} / \mathrm{s}$ & $10 \mathrm{pCi} / \mathrm{m}^{2} / \mathrm{s}$ \\
\hline $\begin{array}{l}\text { Protect Groundwater } \\
\text { Resources }\end{array}$ & No Release (mean) & No Release & See Below \\
\hline - $\begin{array}{c}{ }^{226} \mathrm{Ra}+{ }^{228} \mathrm{Ra} \\
<5 \mathrm{pCi} / \mathrm{L}\end{array}$ & Not Applicable $^{1}$ & Not Applicable ${ }^{1}$ & $0.3 \mathrm{pCi} / \mathrm{L}$ \\
\hline $\begin{array}{l}\text { - Gross alpha } \\
\quad<15 \mathrm{pCi} / \mathrm{L}\end{array}$ & Not Applicable ${ }^{1}$ & Not Applicable ${ }^{1}$ & $9 \mathrm{pCi} / \mathrm{L}$ \\
\hline $\begin{array}{l}\text { - Man-made beta- } \\
\text { gamma emitters } \\
<4 \mathrm{mrem} / \mathrm{yr}\end{array}$ & Not Applicable $^{1}$ & Not Applicable ${ }^{1}$ & $1 \mathrm{mrem} / \mathrm{yr}$ \\
\hline
\end{tabular}

INADVERTENT HUMAN INTRUDER

\begin{tabular}{l|l|l|l}
\hline $500 \mathrm{mrem}$ Acute & $<0.04$ mrem (mean) & $\begin{array}{l}0.2 \text { mrem drilling, } \\
\text { shallow land burial; } \\
22 \mathrm{mrem} \text { drilling, } \\
\text { Pit P06C }\end{array}$ & Not Assessed $^{2}$ \\
\hline $100 \mathrm{mrem} / \mathrm{yr}$ Chronic & $0.04 \mathrm{mrem} / \mathrm{yr}$ (mean) & $\begin{array}{l}157 \mathrm{mrem} / \mathrm{yr} \text { agricultural, } \\
\text { shallow land burial } ; \\
\text { Not applicable (too deep), } \\
\text { agricultural, Pit P06C; } \\
0.7 \text { mrem/yr postdrilling, } \\
\text { shallow land burial; } \\
177 \mathrm{mrem} / \mathrm{yr} \text { postdrilling, } \\
\text { Pit P06C }\end{array}$ & Not $^{2}$ \\
\hline
\end{tabular}

${ }^{1}$ Under the Base Case, there is not a groundwater pathway.

${ }^{2}$ Results would be the same as the Base Case.

${ }^{3}$ Requires monolayer-ET closure cover to be a minimum of $\left.4 \mathrm{~m}(13 \mathrm{ft}]\right)$ thick to comply.

${ }^{4}$ Requires an inventory limit of $174 \mathrm{Ci}$ in Pit P06C to comply. 
DOE/HQ informed NNSA/NSO that while some conditions had been resolved, others remained; and requested that NNSA/NSO provide appropriate documentation to close these outstanding conditions. In January 2002, NNSA/NSO provided DOE/HQ with a letter report addressing the outstanding conditions. In August 2002, DOE/HQ informed NNSA/NSO that all DAS conditions had been closed, but stipulated that two topics be addressed as part of the maintenance program: (1) future revision of the CA will incorporate the dose from the UGTA within Yucca Flat, and (2) minor issues will be tracked in the maintenance program.

\subsubsection{Maintenance Program}

DOE M 435.1-1 Chapter IV, P (4) requires PAs and CAs to be maintained to evaluate changes which could affect the performance, design, and operation of the facility. Maintenance activities may include monitoring, and conducting field studies and research to address uncertainties or data gaps. Current activities include the development of the PA/CA models using the GoldSim ${ }^{\odot}$ probabilistic modeling software. Implementation of models into the GoldSim ${ }^{\circledR}$ platform allows results to reflect the uncertainty of input parameters. Sensitivity analyses are also being conducted to target future efforts. The Area 3 PA/CA models are projected to be fully implemented in the GoldSim ${ }^{\odot}$ platform by the end of FY 2005.

An updated performance assessment will be used to support the final facility closure. 
This Page Intentionally Left Blank 


\subsection{AREA 5 RADIOACTIVE WASTE MANAGEMENT SITE DESCRIPTION}

The facilities, operations, and inventory of wastes at the Area 5 RWMS are discussed in the following sections.

\subsection{Historical Development and Use}

Disposal of radioactive waste at the Area 5 RWMS started in 1961 and, through 1978, eight trenches (T01U, T02U, T04U, T06U, T01C, T03C, T05C, and T06C) were filled primarily with on-site-generated waste and operationally closed. ${ }^{4}$ The Area 5 RWMS began disposing greater amounts of waste from off-site generators in 1978. Between 1978 and September 26, 1988 (the latter date being when DOE O 5820.2A, "Radioactive Waste Management" [now replaced with DOE O 435.1] was promulgated), two pits (P01U and P02U) and one trench (T07U) were filled and operationally closed. Thirteen pits (P03U, P04U, P05U, P06U, P07U, P08U, P09U, P11U, P12U, P13U, P14U, P15U, and P10C) and seven trenches (T03U, T02C, T04C, T04C-1, T07C, $\mathrm{T} 08 \mathrm{C}$, and $\mathrm{T} 09 \mathrm{C}$ ) have been active since promulgation of DOE O 5820.2A; three of these pits (P04U, P05U, and P07U) and all seven trenches (T03U, T02C, T04C, T04C-1, T07C, T08C, and T09C) are now operationally closed, leaving ten currently active pits (P03U, P06U, P08U, P09U, P11U, P13U, P14U, P15U, P10C, and P12C) (Figure 1-3). Most of the MLLW at the Area 5 RWMS was disposed before 1992; however, Pit P03U has accepted small amounts of MLLW generated on site since that time.

The GCD concept was conceived in 1980 when “. . . the National Low-Level Waste Management Program began to review alternatives to the shallow land burial of high specificactivity (HSA) low-level radioactive Wastes." (Dickman et al., 1984).

Between 1983 and 1989, 9 of 13 GCD boreholes were used for disposal of HSA LLW (waste similar to Greater-than-Class C) and TRU and MTRU wastes. Seven boreholes have been filled and operationally closed with backfill of native soil, two boreholes have received waste and remain open, and four boreholes are empty. Waste was remotely placed in the GCD borehole from the bottom to a depth of $21 \mathrm{~m}(70 \mathrm{ft})$ below surface and backfilled with native soil. Two GCD boreholes were active after promulgation of DOE O 5820.2A.

Transuranic waste currently stored at the Area 5 RWMS on an asphalt pad is destined to be disposed at the Waste Isolation Pilot Plant (WIPP) in New Mexico. Shipments of TRU waste to WIPP were started in 2004 and are scheduled to be completed in 2005.

\footnotetext{
4 The Area 5 RWMS was formally established in 1978 with the advent of the NTS Waste Management Program. This disposal site was previously termed "Sugar Bunker Dump Site."
} 


\subsection{Disposal Operations}

Waste to be disposed at the Area 5 RWMS is transported there on trucks. On arrival, manifests are checked and trucks are inspected both visually and with instrumentation to ensure that there is no leakage of contaminated materials from the containers. When cleared, the containers are off-loaded and disposed in the appropriate active pit or trench, depending on waste type or classification, or both. Trucks are released only after being surveyed for contamination. Once disposed or indefinitely stored, waste is covered with approximately $2.4 \mathrm{~m}(8 \mathrm{ft})$ of screened native alluvium. Seven "unclassified" pits (P03U, P06U, P08U, P09U, P13U, P14U, and P15U), and two "classified" pits (P10C and P12C) are currently open for receipt of waste.

Pit P09U is used for drums of LLW. Pit P03U is designated for disposal of MLLW under RCRA interim status; however, only a small amount of NTS-generated mixed waste has been disposed there since 1992. Pit P06U has been deepened for disposal of thorium. The upper portion of P06U is permitted to accept asbestiform waste. Pits P08U, P13U, P14U, and P15U in the expansion area are open for disposal of LLW. Greater Confinement Disposal is not anticipated to be used as a waste disposal option in the future.

\subsection{Ancillary Facilities}

The Area 5 RWMS includes several equipment storage yards and five permanent and nine semipermanent structures that are used for offices, laboratories, storage, utilities, and routine operations. Ancillary to the Area 5 RWMS are a Waste Examination Facility (WEF) and several support structures. The WEF exists to characterize TRU waste stored at the Area 5 RWMS. Neighboring the RWMS are a Hazardous Waste Storage Unit (HWSU) and several administrative support structures. Hazardous wastes are managed at the HWSU until they are shipped off site for disposal.

\subsection{Waste Characteristics}

The facilities, operations, and inventory of wastes at the Area 5 RWMS are discussed in the following sections.

\subsubsection{Waste Containers}

Containers disposed at the Area 5 RWMS are categorized as boxes, drums, or nonstandard. Cardboard, octagonal "tri-wall" boxes were commonly used prior to the mid-1980s. These cardboard boxes were 0.6 or $1.2 \mathrm{~m}$ ( 2 or $4 \mathrm{ft}$ ) high and banded to wooden pallets with steel strapping. Waste was contained in plastic bags inside the cardboard boxes. These boxes were stacked as close to each other as the underlying pallet allowed and were susceptible to crushing if stacked too high. Plywood boxes came into wide use thereafter and range in size from $0.6 \mathrm{~m}$

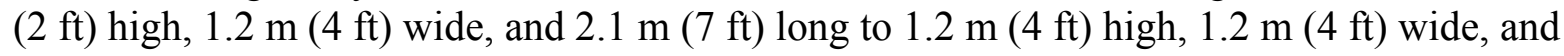
$2.1 \mathrm{~m}(7 \mathrm{ft})$ long. Runners are typically attached to the bottom of the box to facilitate handling with a forklift. Steel boxes became popular in the 1990s. These boxes have standard sizes 
similar to those of plywood boxes. Steel runners or slots for handling with a forklift are typically part of the box design. Both the cardboard and steel boxes are stacked as close to each other as practicable; typically, several inches separate adjacent boxes.

Steel drums in various sizes have been used for disposal at the Area 5 RWMS. Standard 209-liter (L) (55-gallon [gal]) drums and 315-L (83-gal) overpack drums are common; less commonly used are six-drum overpack containers. Drums are stacked vertically on pallets in Pit P09U. Containers other than standard-sized boxes and drums are nonstandard. Many nonstandard containers have been disposed and include unusual shapes or nonstandard-sized boxes or drums. Nonstandard containers are typically stacked to make best use of available pit volume.

\subsubsection{Treatment or Processing Prior to Disposal}

See Section 4.4.2.

\subsubsection{Waste Inventory}

The estimated closure inventory for low-level waste disposed in Area 5 after September 26, 1988, is presented in Table 5.1 (BN, 2004c). The inventory was estimated by summing past disposals through FY 2003 and estimating future disposals. Future disposal estimates were based on forecast waste volumes provided by waste generators. Disposal is assumed to continue until FY 2021. The inventory applicable to CA analyses has not changed and is presented in Shott et al., 1997.

\subsection{Performance Assessment and Composite Analysis}

Description and regulatory requirements for PAs and CAs are presented in Section 4.5.

\subsubsection{Performance Objectives}

Performance Objectives for PAs and CAs are presented in Section 4.5.1.

\subsubsection{Status of Performance Assessment and Composite Analysis}

Upon review of the Area $5 \mathrm{PA}$ and Area $5 \mathrm{CA}, \mathrm{DOE} / \mathrm{HQ}$ issued a conditional DAS for the Area 5 RWMS on December 5, 2000, and required that the specified conditions be addressed within one year of the DAS's issuance. To resolve these conditions, NNSA/NSO submitted to the DOE/HQ in November 2001 two addendum reports (one for the PA and one for the CA) (BN, 2001a,b). Both reports were approved in May 2002, with conditions met and issues closed. Other conditions remain in the DAS, including minor issues that are to be addressed as part of the PA maintenance program, and the condition that NNSA/NSO will incorporate in a future revision of the CA the dose from the UGTA within Frenchman Flat. 
Table 5.1 Area 5 RWMS PA Estimated Inventory (Shott et al., 1998; 1995)

\begin{tabular}{|c|c|c|c|}
\hline & $\begin{array}{l}\text { Geometric } \\
\text { Mean (Ci) }\end{array}$ & $\begin{array}{c}\text { Geometric } \\
\text { Mean } \\
\left(\mathrm{Ci} / \mathbf{m}^{3}\right) \\
\end{array}$ & $\begin{array}{c}\text { Geometric } \\
\text { Standard } \\
\text { Deviation }\end{array}$ \\
\hline H-3 & $1.9 \mathrm{E}+06$ & $5.0 \mathrm{E}+00$ & $2.0 \mathrm{E}+00$ \\
\hline $\mathrm{C}-14$ & $1.3 \mathrm{E}+00$ & $3.4 \mathrm{E}-06$ & $1.9 \mathrm{E}+00$ \\
\hline Al-26 & 2.3E-09 & $6.2 \mathrm{E}-15$ & $3.2 \mathrm{E}+00$ \\
\hline $\mathrm{Cl}-36$ & $3.4 \mathrm{E}-04$ & $9.1 \mathrm{E}-10$ & $2.0 \mathrm{E}+00$ \\
\hline Ar-39 & $1.3 \mathrm{E}-04$ & $3.4 \mathrm{E}-10$ & $2.2 \mathrm{E}+00$ \\
\hline $\mathrm{K}-40$ & $3.2 \mathrm{E}-01$ & $8.4 \mathrm{E}-07$ & $2.0 \mathrm{E}+00$ \\
\hline $\mathrm{Ca}-41$ & $5.0 \mathrm{E}-04$ & $1.3 \mathrm{E}-09$ & $1.9 \mathrm{E}+00$ \\
\hline $\mathrm{Ni}-59$ & $6.9 \mathrm{E}-03$ & $1.8 \mathrm{E}-08$ & $2.2 \mathrm{E}+00$ \\
\hline $\mathrm{Ni}-63$ & $2.6 \mathrm{E}+00$ & 7.0E-06 & $1.8 \mathrm{E}+00$ \\
\hline Co-60 & $1.2 \mathrm{E}+01$ & $3.1 \mathrm{E}-05$ & $2.3 \mathrm{E}+00$ \\
\hline $\mathrm{Kr}-85$ & $8.0 \mathrm{E}-03$ & $2.1 \mathrm{E}-08$ & $1.9 \mathrm{E}+00$ \\
\hline Sr-90 & $1.4 \mathrm{E}+01$ & $3.7 \mathrm{E}-05$ & $1.9 \mathrm{E}+00$ \\
\hline Zr-93 & $8.1 \mathrm{E}-06$ & $2.1 \mathrm{E}-11$ & $2.2 \mathrm{E}+00$ \\
\hline $\mathrm{Nb}-93 \mathrm{~m}$ & $3.8 \mathrm{E}-04$ & $1.0 \mathrm{E}-09$ & $2.1 \mathrm{E}+00$ \\
\hline $\mathrm{Nb}-94$ & $1.0 \mathrm{E}-03$ & $2.7 \mathrm{E}-09$ & $2.1 \mathrm{E}+00$ \\
\hline Tc-99 & $2.9 \mathrm{E}+02$ & 7.6E-04 & $1.9 \mathrm{E}+00$ \\
\hline Pd-107 & $2.6 \mathrm{E}-07$ & $7.0 \mathrm{E}-13$ & $2.2 \mathrm{E}+00$ \\
\hline Ag-108m & $1.8 \mathrm{E}-05$ & $4.9 \mathrm{E}-11$ & $2.1 \mathrm{E}+00$ \\
\hline Cd-113m & $2.6 \mathrm{E}-03$ & $6.9 \mathrm{E}-09$ & $2.1 \mathrm{E}+00$ \\
\hline $\mathrm{Sn}-121 \mathrm{~m}$ & $4.2 \mathrm{E}-04$ & $1.1 \mathrm{E}-09$ & $2.1 \mathrm{E}+00$ \\
\hline Sn-126 & $8.0 \mathrm{E}-06$ & $2.1 \mathrm{E}-11$ & $2.2 \mathrm{E}+00$ \\
\hline I-129 & 4.7E-02 & $1.2 \mathrm{E}-07$ & $2.0 \mathrm{E}+00$ \\
\hline Cs-135 & $6.1 \mathrm{E}-06$ & $1.6 \mathrm{E}-11$ & $2.2 \mathrm{E}+00$ \\
\hline Cs-137 & $2.1 \mathrm{E}+01$ & $5.6 \mathrm{E}-05$ & $1.9 \mathrm{E}+00$ \\
\hline Ba-133 & $9.9 \mathrm{E}-02$ & $2.6 \mathrm{E}-07$ & $2.2 \mathrm{E}+00$ \\
\hline Pm-145 & $6.0 \mathrm{E}-06$ & $1.6 \mathrm{E}-11$ & $2.3 \mathrm{E}+00$ \\
\hline Sm-151 & 7.4E-03 & $2.0 \mathrm{E}-08$ & $2.2 \mathrm{E}+00$ \\
\hline Eu-150 & $1.6 \mathrm{E}-05$ & $4.1 \mathrm{E}-11$ & $3.1 \mathrm{E}+00$ \\
\hline Eu-152 & $1.6 \mathrm{E}-02$ & 4.1E-08 & $1.9 \mathrm{E}+00$ \\
\hline Eu-154 & $2.4 \mathrm{E}-03$ & $6.5 \mathrm{E}-09$ & $2.0 \mathrm{E}+00$ \\
\hline Gd-148 & $3.5 \mathrm{E}-07$ & $9.2 \mathrm{E}-13$ & $2.0 \mathrm{E}+00$ \\
\hline Gd-152 & $1.4 \mathrm{E}-15$ & $3.7 \mathrm{E}-21$ & $1.8 \mathrm{E}+00$ \\
\hline vHo-166m & $1.5 \mathrm{E}-09$ & $4.1 \mathrm{E}-15$ & $2.2 \mathrm{E}+00$ \\
\hline $\mathrm{Pb}-210$ & $1.6 \mathrm{E}+00$ & $4.2 \mathrm{E}-06$ & $1.6 \mathrm{E}+00$ \\
\hline Bi-207 & $2.5 \mathrm{E}-06$ & $6.7 \mathrm{E}-12$ & $2.1 \mathrm{E}+00$ \\
\hline Ra-226 & $1.7 \mathrm{E}+00$ & 4.6E-06 & $1.8 \mathrm{E}+00$ \\
\hline $\mathrm{Ra}-228$ & $2.3 \mathrm{E}+01$ & $6.0 \mathrm{E}-05$ & $1.8 \mathrm{E}+00$ \\
\hline Ac-227 & $8.2 \mathrm{E}-02$ & $2.2 \mathrm{E}-07$ & $1.6 \mathrm{E}+00$ \\
\hline Th-228 & $2.3 \mathrm{E}+01$ & $6.0 \mathrm{E}-05$ & $1.7 \mathrm{E}+00$ \\
\hline Th-229 & $8.7 \mathrm{E}-03$ & $2.3 \mathrm{E}-08$ & $1.8 \mathrm{E}+00$ \\
\hline Th-230 & $1.2 \mathrm{E}+01$ & $3.1 \mathrm{E}-05$ & $1.8 \mathrm{E}+00$ \\
\hline Th-232 & $2.2 \mathrm{E}+01$ & $6.0 \mathrm{E}-05$ & $1.8 \mathrm{E}+00$ \\
\hline
\end{tabular}


Table 5.1 (continued)

\begin{tabular}{lccc}
\cline { 2 - 4 } & $\begin{array}{c}\text { Geometric } \\
\text { Mean (Ci) }\end{array}$ & $\begin{array}{c}\text { Geometric } \\
\text { Mean } \\
\left(\mathbf{C i} / \mathbf{m}^{3}\right)\end{array}$ & $\begin{array}{c}\text { Geometric } \\
\text { Standard } \\
\text { Deviation }\end{array}$ \\
\hline Pa-231 & $8.9 \mathrm{E}-02$ & $2.4 \mathrm{E}-07$ & $1.5 \mathrm{E}+00$ \\
$\mathrm{U}-232$ & $5.4 \mathrm{E}-02$ & $1.4 \mathrm{E}-07$ & $2.0 \mathrm{E}+00$ \\
$\mathrm{U}-233$ & $3.4 \mathrm{E}+00$ & $9.1 \mathrm{E}-06$ & $2.0 \mathrm{E}+00$ \\
$\mathrm{U}-234$ & $2.3 \mathrm{E}+03$ & $6.2 \mathrm{E}-03$ & $1.8 \mathrm{E}+00$ \\
$\mathrm{U}-235$ & $1.0 \mathrm{E}+02$ & $2.8 \mathrm{E}-04$ & $1.7 \mathrm{E}+00$ \\
$\mathrm{U}-236$ & $6.7 \mathrm{E}+01$ & $1.8 \mathrm{E}-04$ & $1.9 \mathrm{E}+00$ \\
$\mathrm{U}-238$ & $4.9 \mathrm{E}+03$ & $1.3 \mathrm{E}-02$ & $1.8 \mathrm{E}+00$ \\
$\mathrm{~Np}-237$ & $1.5 \mathrm{E}+00$ & $3.9 \mathrm{E}-06$ & $1.8 \mathrm{E}+00$ \\
$\mathrm{Pu}-236$ & $1.6 \mathrm{E}-10$ & $4.3 \mathrm{E}-16$ & $2.8 \mathrm{E}+00$ \\
$\mathrm{Pu}-238$ & $1.0 \mathrm{E}+02$ & $2.7 \mathrm{E}-04$ & $1.8 \mathrm{E}+00$ \\
$\mathrm{Pu}-239$ & $1.8 \mathrm{E}+02$ & $4.7 \mathrm{E}-04$ & $1.7 \mathrm{E}+00$ \\
$\mathrm{Pu}-240$ & $3.8 \mathrm{E}+01$ & $1.0 \mathrm{E}-04$ & $1.7 \mathrm{E}+00$ \\
$\mathrm{Pu}-241$ & $8.7 \mathrm{E}+01$ & $2.3 \mathrm{E}-04$ & $1.8 \mathrm{E}+00$ \\
$\mathrm{Pu}-242$ & $1.8 \mathrm{E}-02$ & $4.8 \mathrm{E}-08$ & $2.0 \mathrm{E}+00$ \\
$\mathrm{Pu}-244$ & $1.5 \mathrm{E}-14$ & $4.1 \mathrm{E}-20$ & $1.9 \mathrm{E}+00$ \\
$\mathrm{Am}-241$ & $3.6 \mathrm{E}+01$ & $9.5 \mathrm{E}-05$ & $1.6 \mathrm{E}+00$ \\
$\mathrm{Am}-242 \mathrm{~m}$ & $7.0 \mathrm{E}-02$ & $1.9 \mathrm{E}-07$ & $2.0 \mathrm{E}+00$ \\
$\mathrm{Am}-243$ & $4.7 \mathrm{E}-03$ & $1.3 \mathrm{E}-08$ & $1.9 \mathrm{E}+00$ \\
$\mathrm{Cm}-242$ & $5.8 \mathrm{E}-02$ & $1.5 \mathrm{E}-07$ & $2.0 \mathrm{E}+00$ \\
$\mathrm{Cm}-243$ & $1.4 \mathrm{E}-03$ & $3.7 \mathrm{E}-09$ & $1.9 \mathrm{E}+00$ \\
$\mathrm{Cm}-244$ & $2.0 \mathrm{E}-01$ & $5.3 \mathrm{E}-07$ & $2.1 \mathrm{E}+00$ \\
$\mathrm{Cm}-245$ & $1.3 \mathrm{E}-03$ & $3.6 \mathrm{E}-09$ & $2.1 \mathrm{E}+00$ \\
$\mathrm{Cm}-246$ & $2.2 \mathrm{E}-04$ & $5.8 \mathrm{E}-10$ & $2.2 \mathrm{E}+00$ \\
$\mathrm{Cm}-248$ & $9.2 \mathrm{E}-08$ & $2.5 \mathrm{E}-13$ & $1.9 \mathrm{E}+00$ \\
$\mathrm{Cf}-249$ & $7.8 \mathrm{E}-05$ & $2.1 \mathrm{E}-10$ & $2.1 \mathrm{E}+00$ \\
$\mathrm{Cf}-251$ & $1.8 \mathrm{E}-04$ & $4.7 \mathrm{E}-10$ & $2.1 \mathrm{E}+00$ \\
$\mathrm{Cf}-252$ & $9.1 \mathrm{E}-05$ & $2.4 \mathrm{E}-10$ & $2.6 \mathrm{E}+00$ \\
\hline Total & $\mathbf{1 . 9 E}+06$ & $\mathbf{5 . 0 E}+\mathbf{0 0}$ & \\
\hline & & & \\
\hline
\end{tabular}

\subsubsection{Maintenance Program}

Maintenance program activities are presented in Section 4.5.3. The Area 5 PA/CA models are projected to be fully implemented in the GoldSim ${ }^{\circledR}$ platform by the end of FY 2005. 
This Page Intentionally Left Blank 


\subsection{CLOSURE COVER DESIGN}

Because performance objectives of the PAs are generally exceeded with only an operational closure cover, an approach for the final closure cover will be taken for both closure and monitoring that emphasizes simplicity of design and maintenance.

\subsection{Operational Closure Cover}

The operational closure cover is screened native soil that is placed over disposed waste containers to provide temporary protection to the containers and containment of the contents. Operational closure covers are designed to have equivalent performance to standard closure

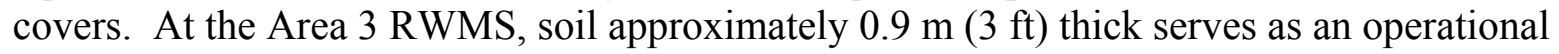
cover between each tier of waste. In the past, operational closure covers at the Area 5 RWMS were $2.1 \mathrm{~m}(8.0 \mathrm{ft})$ thick, with approximately equal thicknesses below and above grade. New

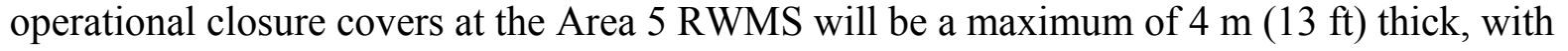
$1.2 \mathrm{~m}(4 \mathrm{ft})$ below grade and $2.8 \mathrm{~m}(9 \mathrm{ft})$ above grade.

\subsection{Final Closure Cover}

The basic closure cover design for all of the disposal units will be of the vegetated monolayer-ET type (Figure 6.1). A vegetated monolayer-ET closure cover was deployed in FY 2000 at the Central Nevada Test Area north of the NTS, and early in FY 2001 on U-3ax/bl at the Area 3 RWMS (DOE, 2000a). In some cases, the basic design may require modest modification to ensure long-term containment. Such modifications will be dealt with on a case-by-case basis. An instrumented drainage lysimeter facility near the Area 5 RWMS and a similar facility constructed in 2001 at the Area 3 RWMS will collect data over at least the next several years that are useful to optimize the design of the closure covers for specific units.

A monolayer-ET closure cover was selected as the preferred alternative design to a multilayered landfill closure cover and other alternative designs only after a comprehensive evaluation of many alternatives. Evaluation of alternative designs included review of relevant literature, research on water balance in vegetated and unvegetated weighing lysimeters in Area 5 of the NTS, hydrogeologic modeling, site visits to closure cover test facilities at SNL and Los Alamos National Laboratory (LANL), NNSA/NSO-sponsored workshops, and a conference on vadose zone monitoring. The various forums included representatives from industry, academia, and government, including SNL and LANL, and provided the opportunity to discuss closure and monitoring of waste-disposal units. Multiple lines of evidence suggest that a monolayer-ET design in an arid environment will perform according to performance criteria over long periods of time even under conditions of subsidence and will meet the regulatory standards and performance objectives listed in Section 2.1.2. The monolayer-ET cover and natural conditions at the NTS will integrate and operate as a system.

Natural conditions that optimize the system are extremely low precipitation and high potential evapotranspiration rates, large depth to groundwater, and negligible recharge to groundwater. 


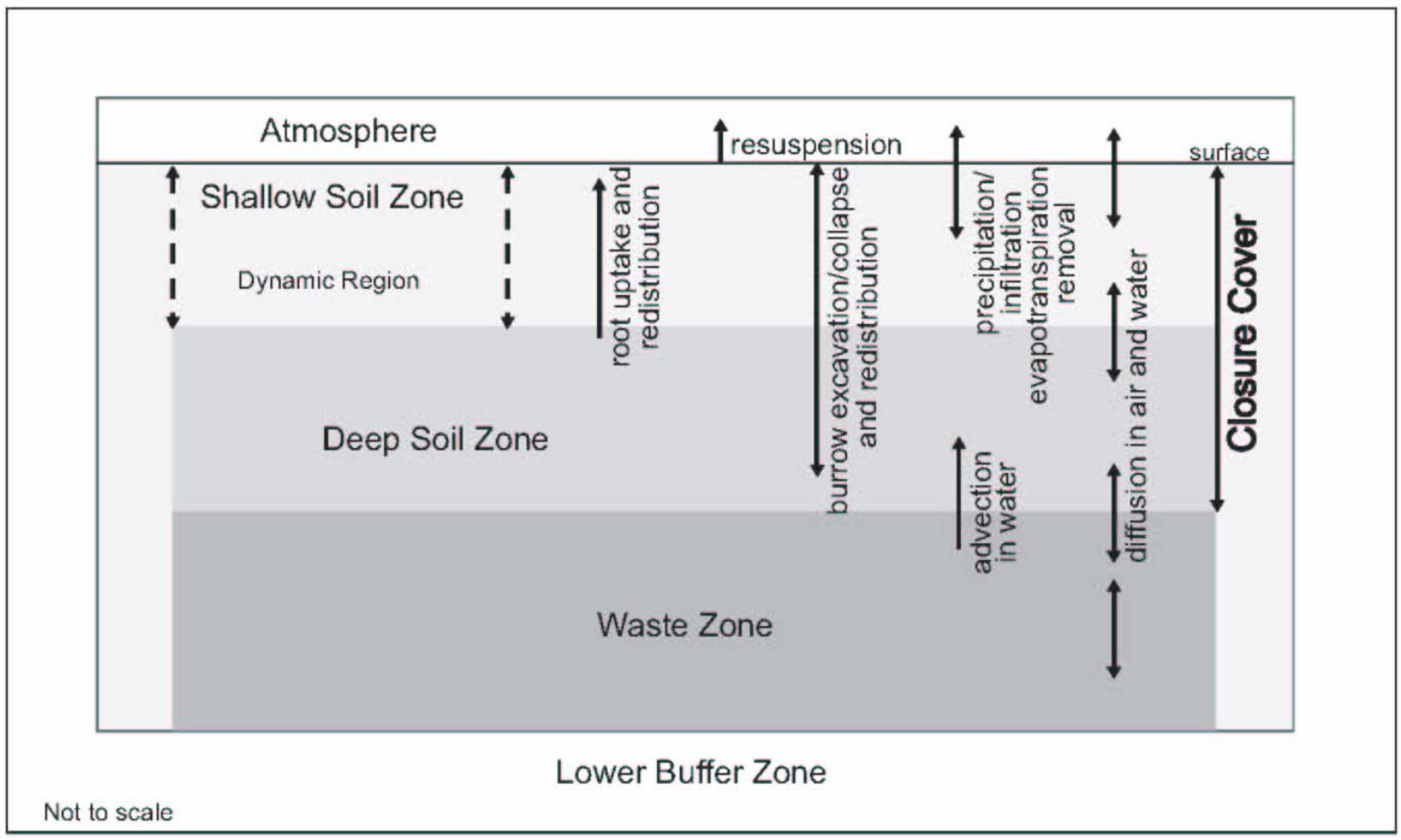

Figure 6.1

Conceptual model of an evapotranspiration closure cover over waste in shallow land burial

\subsubsection{Cover Composition}

The operational and final closure covers will be constructed of screened native soil. The soil at the Area 3 RWMS and vicinity is finer grained than soil at the Area 5 RWMS, however soils at both locations are classified as gravelly sand. The percentages of sand and gravel in samples collected from operational covers at the Area 5 RWMS are 79 and 21 percent, respectively (BN, 2002).

\subsubsection{Cover Vegetation}

Vegetation plays an important role in cover stability and functionality by stabilizing cover soil to reduce erosion by wind and water run off. Cover functionality is improved in that moisture is drawn out of the cover by roots and transpired to the atmosphere.

Cover vegetation will be selected to include native plant species with shallow rooting depths. Studies by Wirth et al. (1999) and Hansen and Ostler (2003) identified several native species whose rooting depths were less than $51 \mathrm{~cm}$ (20 in). This depth provides a good balance between cover stability and impact to the waste unit because the rooting depth is a fraction of the total cover thickness. 
Seeding will be conducted using a sprayer and a hose with an adjustable nozzle; planting will be conducted manually. The seeds or plantings are typically covered with straw and irrigated as necessary to ensure successful root development. The vegetation is generally planted on the closure cover in the winter to reduce the water requirement.

\subsubsection{Water Infiltration}

Measurement and modeling of water balance in test monolayer-ET covers at the Area 5 RWMS and at National Laboratories in arid regions of the United States show that the design will minimize infiltration of water (Levitt et al., 1998; Dwyer, 1998).

Water balance studies conducted at the Area 5 RWMS have shown that a monolayer-ET closure cover is most effective when vegetated (Levitt et al., 1999). Under current climatic conditions, any water that infiltrates into the soil is quickly extracted by evaporation and uptake by plant roots, even with a relatively low density of plant cover. Closure covers constructed over waste units at both the Area 3 and Area 5 RWMSs will be planted with species native to the area. Shallow-rooted, invasive plant species will also be allowed to vegetate the closure covers. Over the long term, an established plant assemblage is expected that will survive the ambient range of environmental conditions. Plants will also serve to maintain stability of the closure covers. The cover will have adequate slope to safely carry any precipitation runoff without significant erosion.

\subsubsection{Plant Rooting and Animal Burrowing}

Animal burrowing is closely related to plant rooting depths (see Section 6.2.2). Burrows generally do not extend deeper than the depth of plant roots (Neptune \& Co., 2004). This is the result of greater moisture and food availability in the root zone. The advantage of using shallowrooted plants with respect to animal burrowing is that shallow rooting greatly reduces the likelihood of deep burrowing which could result in degradation of cover effectiveness.

\subsubsection{Inadvertent Intruder Barrier}

The monolayer-ET closure cover does not include a barrier against inadvertent human intrusion (IHI). The thickness of the cover provides partial protection, but the greatest reliance is placed on a small probability of this occurrence, and on institutional control. The probability of IHI was the subject of an investigation of site-specific scenarios for IHI into waste disposed at the Area 3 and Area 5 RWMSs. The intrusion scenarios focused on drilling for water in both Yucca Flat and Frenchman Flat, driven by an individual homesteader scenario and several community settlement scenarios (Black et al., 2001). A panel of subject matter experts (SMEs) convened to elicit the probability of IHI into a waste unit considered the effectiveness of management controls on reducing the probability of intrusion. Management controls, which include institutional control, site knowledge, placards and markers, and surface and subsurface barriers, were thought by the panel to be effective only for the first few centuries; some controls were considered to be more effective than others. For example, surface barriers could effectively control siting of a drill rig over a waste unit; whereas subsurface barriers and placards and markers were much less likely to 
control drilling. Remoteness and harsh environmental conditions of both Yucca Flat and Frenchman Flat, and the presence of playas and subsidence craters, were thought by the panel to be the most important factors affecting the probability of drilling, and thus intrusion. One of several community scenarios, a community settlement that develops from an industrial-technological complex in a nearby, yet more accessible valley, and has commuter homesteaders living in Frenchman Flat, yielded the greatest probability of inadvertent intrusion; that is, about 10 percent.

Institutional control is discussed in Section 8.1.

\subsubsection{Cover Integrity and Stability}

Design of any closure cover will have to consider the potential for plant root intrusion into disposed waste, a potential pathway for release of radionuclides. Cover designs will also have to consider the potential for animals burrowing into the closure cover or, less likely, into disposed waste. Burrowing by animals could degrade cover integrity, alter hydraulic properties of the cover, or transport radionuclides to the accessible environment (Hankonson et al., 1992). Mobile fauna could disperse contamination to distant sites, and animals could introduce contamination into trophic pathways, eventually leading to humans that consume wild game (O'Farrell and Gilbert, 1975). Design alternatives to mitigate these conditions will be included in closure plans specific to individual disposal units or groups of units.

The structural stability of the closure cover would be affected by differential subsidence that would occur intermittently following infilling of void space around containers, and degradation and collapse of disposed waste containers. Values of parameters affecting subsidence such as volume of void space, as well as estimates of subsidence, are described in Shott et al. (1998, 1995), Barker (1997), and Obi et al. (1996). During a period of active institutional control, any subsidence that might occur would be immediately mitigated by filling and grading the subsided spots with native soil, thus ensuring structural stability of the cover at all times. Any major damage to vegetation on the closure covers from maintenance activities will be corrected by replanting. Part of the total expected subsidence may have taken place by the end of the active institutional control period. The monolayer-ET cover design will intrinsically be structurally stable in that it does not include layers which, if displaced, would render the cover ineffective. The cover, however, will have to be of adequate thickness to accommodate some, but perhaps not all, subsidence over time. The cover itself is expected to erode; depressions will fill with sediment eroded from surrounding areas of the cover. The design of the closure cover will include proper surface and side slopes, and perhaps limited armoring, to permit drainage but not channelized erosion.

\subsubsection{Cover Configuration, Site Grading, and Drainage}

Because of the distances between waste disposal units at the Area 3 RWMS, each unit will have an independent, above-grade final closure cover. The final closure covers will incorporate any operational tiers or covers, and have a maximum constructed thickness of $4 \mathrm{~m}(13 \mathrm{ft})$, with the exception of U-3ax/bl (CAU 110). Disposal unit U-3ax/bl was closed in 2001 with a final 
closure cover approximately $3 \mathrm{~m}(10 \mathrm{ft})$ thick. The final closure covers will be graded to provide drainage off the covers, and areas between the units will be graded so that drainage will not impact adjacent closed units, and then exit the site.

The final closure cover at the 92-ac area of the Area 5 RWMS will cover all the disposal units within the 92 -ac area and have a maximum constructed thickness of $4 \mathrm{~m}(13 \mathrm{ft})$. The closure cover will extend beyond the boundaries of the disposal units the same distance as the abovegrade thickness of the closure cover and will be contoured to provide a 1:1 side slope. The final closure cover will incorporate all the operational covers and add only the quantity of soil needed to provide for final grading and a base for seeding or planting. To provide drainage, while not inducing erosion, the cover will be sloped southwest at approximately 2 percent so that the northeast part of the final cover will be slightly higher in elevation than the southwest portion of the closure cover.

The Area 5 RWMS expansion area will be closed with a single closure cover in a similar fashion as the 92-ac area. Areas between the final covers on the expansion area and the 92-ac area will be graded so that drainage will exit the site without impacting adjacent closed units.

\subsubsection{Cover Security, Markers, and Protection}

Security plans for the Area 3 and 5 RWMSs will be part of the final closure plans for these sites or disposal units within these sites. The disposal areas are currently secured 24 hours, 7 days a week, with security maintained with the following systems:

- Access requires prior authorization and an escort if not previously authorized to enter.

- Perimeter markers, a perimeter fence, and gated access road to the disposal-unit area, with postings of the hazards and access requirements.

- Classified areas have additional markers, fencing, and postings, and are routinely checked by the NTS security force.

The fences will prevent access to most animals to eliminate their eating of the native vegetation, while keeping unauthorized personnel from performing intrusive activities at the site. 
This Page Intentionally Left Blank 


\subsection{CLOSURE APPROACH}

Closure of the Area 3 and Area 5 RWMSs includes operational closure followed by final closure. Operational closure provides the initial protection and containment of disposed waste containers. Final closure provides containment of disposed wastes for an indefinite period.

\subsection{Operational Closure}

Containerized waste is disposed in pits or trenches starting at the closed end of the disposal unit and progressing toward the open or ramp end. An alphanumeric grid system along the perimeter of the disposal unit is used to track the location of all disposed waste. Within a short time (days to weeks) after disposal of the waste, stockpiled soil is screened and placed over the waste containers from the top of the stacked containers. The working face of the stacked waste containers is not immediately covered with soil, so that additional waste can be stacked easily. The soil cover is not placed in lifts and the only compaction is from the heavy equipment running over the total thickness of soil.

\subsubsection{Area 3 Radioactive Waste Management Site}

A primary difference in approach to operational closure between the Area 3 and Area 5 RWMSs is that waste at the Area 3 RWMS is disposed in tiers. Tiers are necessary to keep the height of stacked waste packages relatively low to ensure worker safety. Depending on the disposal unit, a tier may consist of unpackaged bulk waste (U-3ax/bl), waste soil in soft-sided packages (U-3bh), or packaged waste (U-3ah/at). As a tier of waste is placed from one side of the unit toward the other side, the waste is progressively covered with $0.9 \mathrm{~m}(3 \mathrm{ft})$ of screened native alluvium. (Soft-sided packages are covered with $0.3 \mathrm{~m}$ [1 ft] of alluvium.) Each tier, when complete, extends over the entire floor of the disposal unit. With the exception of U-3ax/bl, disposal units at the Area 3 RWMS will be operationally closed above grade. Alternating tiers of waste and alluvium will be brought to within $1.2 \mathrm{~m}$ (4 ft) of grade, and a maximum 4-m- (13-ft)-thick operational cover will be placed as at the Area 5 RWMS.

Disposal unit U-3ax/bl is the only unit at the Area 3 RWMS to have been filled and operationally and finally closed; the other two active disposal units are partially filled. Before final closure,

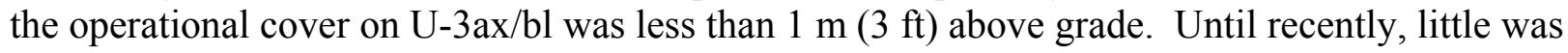
known of the construction of the operational cover because at the time of closure, a recognized closure program was not in place. A ground-penetrating radar survey of the cover conducted in November 1999 showed the top $1.2 \mathrm{~m}(4 \mathrm{ft})$ to be homogeneous, and the interval between 1.2 and $3 \mathrm{~m} \mathrm{(4} \mathrm{and} 10 \mathrm{ft}$ ) to be slightly heterogeneous but relatively free of disposed waste (DOE,

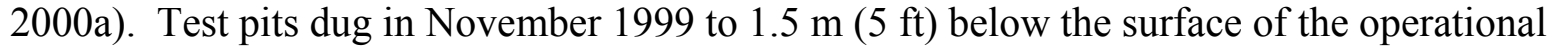
cover, and probing of the cover to $2.7 \mathrm{~m}(9 \mathrm{ft})$ below the surface conducted prior to the radar survey, corroborate results of the radar survey. Most dry densities of samples collected from the test pits ranged approximately between 1.5 and 1.9 kilograms $(\mathrm{kg}) / \mathrm{m}^{3}(90$ and 110 pounds $\left.[\mathrm{lbs}] / \mathrm{ft}^{3}\right)$ and calculated permeabilities of samples ranged approximately between $1.00 \mathrm{E}-3$ and $1.00 \mathrm{E}-6 \mathrm{~cm} / \mathrm{s}(4.00 \mathrm{E}-4$ and $4.00 \mathrm{E}-7 \mathrm{in} / \mathrm{s})$, with the mean permeability being approximately $1.00 \mathrm{E}-5 \mathrm{~cm} / \mathrm{s}(4.00 \mathrm{E}-6 \mathrm{in} / \mathrm{s})(\mathrm{DOE}, 2000 \mathrm{a})$. Because the method of placing the operational cover 
is generally the same between units and between the two RWMSs, these ranges of values for density and permeability may be generally representative of all the operational closure covers. Determination of density and permeability on operationally closed disposal units will be part of the final closure process.

\subsubsection{Area 5 Radioactive Waste Management Site}

Native soil excavated to form trenches at the Area 5 RWMS is typically stockpiled for later use in operational closure. Waste containers are stacked in the disposal unit to approximately $1.2 \mathrm{~m}$ (4 ft) below grade. Aluminum tubes used later for neutron monitoring of soil moisture were previously placed at intervals between waste containers during stacking. The neutron monitoring tubes extend to the bottom of the disposal unit. The previously installed neutron monitoring technology has been essentially replaced by time-domain reflectometry (TDR) probes. Existing neutron monitoring tubes are not currently used and are to be filled and abandoned. Neutron monitoring tubes will not be placed during future waste-disposal activities.

Within a short time after disposal, stockpiled soil is screened to remove rocks larger than $9 \mathrm{~cm}$ ( 3.5 in) and then placed from the top of the un-open end of the disposal unit over the stacked packages. The front end of the waste is not covered with soil so that additional waste can be stacked easily. Past operational closure included placement of soil over the waste containers to a

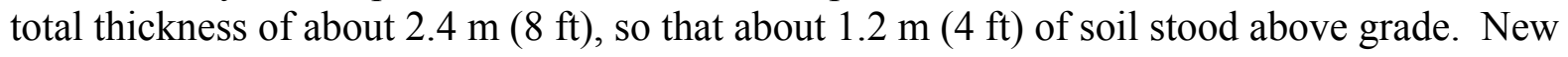
operational closures will place soil over the waste containers to a total thickness of about $4 \mathrm{~m}$ $(13 \mathrm{ft})$, so that $2.8 \mathrm{~m}$ (9 $\mathrm{ft}$ ) of soil stand above grade. This additional thickness will preclude biotic intrusion into the waste zone. A maximum 4-m- (13-ft)-thick cover will also optimize performance in terms of attenuating the flux of gaseous radionuclides, and accommodating infiltration of water and any later subsidence. The lower existing operational covers, when adjacent to a new cover, will be thickened to match the total thickness of the newly placed operational cover, and together sloped to provide appropriate drainage from the unit and away from the adjacent units.

Prior to final placement of waste containers, soil will be placed at the base of existing waste containers and up the unit's side and then sloped to provide stability. Any open space between the side pit wall and the waste containers will be filled with soil. After a disposal unit is completely filled, the operational cover is graded to provide a smooth surface. Maintenance of the cover includes filling of fissures and depressions resulting from compaction and piping of soil between waste packages, and compaction of the surface with a roller and re-grading. Operational closure covers are not vegetated because of the need for continued maintenance activities.

Two weighing lysimeters installed near the Area 5 RWMS, one vegetated and the other bare, serve as analogs for the operational closure covers. Data collected over the past five years show that soil in the unvegetated lysimeter stores more water than similar soil in the vegetated lysimeter and, over a period of approximately five years, could have slight infiltration through

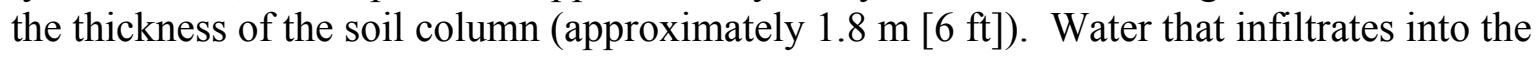
vegetated lysimeter, however, is quickly removed by evapotranspiration. To date, no water has 
drained through the bottom of either lysimeter. Modeling conducted for final closure of disposal unit U-3ax/bl shows that water is effectively removed from the soil column with as little as 20 percent vegetation cover (DOE, 2000a). Several instrumented drainage lysimeters have been installed at the Area 3 RWMS for further verification.

\subsection{Final Closure}

Waste disposed at the Area 3 and Area 5 RWMSs can be categorized based on security requirements, waste type, and disposal configuration (Table 7.1). Several GCD boreholes contain no waste; these have been designated to the appropriate category based on intended use in terms of classification. The criteria defining the categories of disposed waste, along with the spatial distribution of waste units at each of the RWMSs, provide logical groups of waste units when considering the activities, interactions, and documentation required to support closure. Such grouping of disposal units will allow key differences that might require different interactions or engineering to be adequately addressed in final closure documentation.

\subsubsection{Area 3 Radioactive Waste Management Site}

Waste disposal unit U-3ax/bl was closed according to RCRA requirements in FY 2001. A nominal $0.3-\mathrm{m}$ - (1-ft-)-thick monolayer-ET closure cover composed of locally derived soil was placed over an existing above-grade operational closure cover, providing approximately $3 \mathrm{~m}$ $(10 \mathrm{ft})$ of cover over the waste zone. The ET closure cover was graded to provide for runoff of precipitation and then vegetated with local species by both seeding and planting. The cover is being monitored with TDR in four locations as agreed upon with the NDEP. Closure of $\mathrm{U}-3 \mathrm{ax} / \mathrm{bl}$ will serve as a template for closure of U-3bh and U-3ah/at, even though the other two disposal units do not contain hazardous constituents and will not be closed under the purview of RCRA requirements.

Design of the final closure cover for U-3bh and U-3ah/at will be established in a site-specific closure plan, but will likely be similar to the final cover placed on disposal unit U-3ax/bl. The disposal units will be graded to provide for precipitation runoff and then vegetated in a like manner as U-3ax/bl. Each of these disposal units will have an independent closure cover. The areas between the covers will be graded to provide drainage that does not impact an adjacent disposal unit.

Monitoring will be conducted according to the closure plan developed specifically for the Area 3 RWMS. One approach to monitoring the individual covers could be to use the adjacent drainage lysimeter facility as a surrogate for monitoring the individual units.

\subsubsection{Area 5 Radioactive Waste Management Site}

The Area 5 RWMS Atlas facility (maintained by the M\&O contractor) shows several operationally closed LLW disposal units within the 92-ac area that may contain hazardous constituents. Because the basis for this determination is unknown, a review of paper records of waste received from 1961 through 1976, and of electronic records of waste received from 1977 
Table 7.1 Categories of disposal units at the Area 3 RWMSs based on security requirements, waste type, and disposal configuration. Disposal units that contain hazardous constituents compose CAU 111 and require involvement of the NDEP in the closure activities.

\begin{tabular}{|c|c|c|c|c|}
\hline Category & Units & $\begin{array}{c}\text { Security } \\
\text { Requirements }\end{array}$ & $\begin{array}{c}\text { Waste } \\
\text { Type/ } \\
\text { Material }\end{array}$ & $\begin{array}{c}\text { Disposal } \\
\text { Configuration }\end{array}$ \\
\hline 1 & $\begin{array}{l}\text { T07U, T03U, P06U (thorium and } \\
\text { asbestiform), P04U, P05U, P07U } \\
\text { (asbestiform), P08U, P11U, P13U, } \\
\text { P14U, P15U }\end{array}$ & "Unclassified” & \multirow[t]{2}{*}{ LLW } & \multirow[t]{5}{*}{$\begin{array}{l}\text { Shallow Land } \\
\text { Disposal }\end{array}$} \\
\hline 2 & $\begin{array}{l}\text { T02C, T07C, T08C, T09C, P10C, } \\
\text { P12C }\end{array}$ & "Classified" & & \\
\hline 3 & $\begin{array}{l}\text { T01U, T02U, T04U, T06U, P01U, } \\
\text { P02U, P03U }\end{array}$ & "Unclassified” & MLLW & \\
\hline 4 & T01C, T03C, T04C-1, T05C, T06C & \multirow[t]{2}{*}{ "Classified" } & & \\
\hline 5 & T04C & & $\begin{array}{l}\text { MLLW/ } \\
\text { TRU }\end{array}$ & \\
\hline 6 & $\begin{array}{l}\text { GCDT, GCD-05U, GCD-06U, GCD- } \\
\text { 09U (empty,) GCD-10U, GCD-11U } \\
\text { (empty), GCD-12U (empty) }\end{array}$ & "Unclassified" & LLW & \multirow[t]{4}{*}{$\begin{array}{l}\text { Greater } \\
\text { Confinement } \\
\text { Disposal }\end{array}$} \\
\hline 7 & $\begin{array}{l}\text { GCD-07C (probable solvents [F001- } \\
\text { F005]), GCD-08C (empty) }\end{array}$ & \multirow[t]{3}{*}{ "Classified" } & MLLW & \\
\hline 8 & GCD-02C & & TRU & \\
\hline 9 & $\begin{array}{l}\text { GCD-01C (LiD [D003]), GCD-03C } \\
\text { (melted high explosive); GCD-04C } \\
\text { (LiH [D003]; probable solvents [F001- } \\
\text { F005]) }\end{array}$ & & MTRU & \\
\hline 10 & U-3bh, U-3ah/at & \multirow[t]{2}{*}{ "Unclassified" } & LLW & \multirow{2}{*}{$\begin{array}{l}\text { Shallow Land, } \\
\text { Crater Disposal }\end{array}$} \\
\hline 11 & $\mathrm{U}-3 \mathrm{ax} / \mathrm{bl}$ & & MLLW & \\
\hline
\end{tabular}

from 1977 through 1988 was conducted to verify to the extent possible which disposal units might contain hazardous constituents regulated under the RCRA. At the time of disposal, these wastes were not regulated or defined as mixed waste. A CAU of "retired mixed waste cells" (citing from the RCRA Permit NEV HW009) is proposed based on this evaluation. The "retired mixed waste cells" are within a group of waste disposal units that were opened, and generally operationally closed prior to January 1987, when P03U was opened for disposal of waste with hazardous constituents. 
Disposal units that contain only LLW, or that contain LLW and TRU waste, will be closed according to regulations imposed by NNSA/NSO in the process of self-regulation. CAU 111 and the Pit 3 MWDU will be closed in concert with the NDEP according to RCRA requirements and regulations imposed by NNSA/NSO in the process of self-regulation (Table 7.1).

Pending approval of the NDEP as necessary, the NNSA/NSO will add native soil to disposal units composing the CAU and to all other operationally closed units within the 92-ac area. The addition of soil is comparable to the approach taken to close U-3ax/bl (CAU 110) at the Area 3 RWMS in FY 2001. Prior to placement of additional soil, characterization of the disposal units will be conducted and reported to the NNSA/NSO and NDEP with the intent of providing sufficient documentation to demonstrate that the action will not adversely impact the regulated disposal units. Results of past characterization studies, and ongoing measures of water balance at the Area 5 RWMS and elsewhere, are believed to provide sufficient data to show that initial characterization activities will be minimal.

Placement of soil on the operational closure covers as part of operations will leave as the steps of final closure, the addition of "shaping" soil, final grading, and planting of vegetation, either by seeding or planting.

Closure activities for waste disposal units in the expansion area north of the Area 5 RWMS 92-ac area are scheduled over the time frame of FY 2019 through 2021. Closure activities for the Area 3 RWMS are scheduled to occur between FY 2006 and FY 2008.

\subsection{Certification of Closure}

NNSA/NSO will submit to NDEP via registered mail, a certification that the RCRA-regulated disposal units have been closed according to the specifications of the closure plans for those units [Title 40 CFR 264.115]. Submittal of the certification will occur within 60 days of completion of final closure of the Area 5 RWMS 92-ac area.

\subsection{Site Survey Plat}

The NNSA/NSO will submit to the NDEP a survey plat (Title 40 CFR 264.116) of the closed Area 5 RWMS 92-ac area, including the location and dimensions of the regulated disposal units. The survey plat will be submitted prior to or with the certification of closure. 
This Page Intentionally Left Blank 


\subsection{POST-CLOSURE CARE AND STRATEGY}

Following certification of closure of the Area 3 and 5 RWMSs, according to DOE O 435.1 and DOE M 435.1-1, the facilities will be subject initially to a period of active institutional control followed by an indefinite period of passive control. The NNSA position is that the NTS will be controlled in perpetuity. However, should this position change for part or all of the NTS, institutional control shall continue until the facility can be released pursuant to DOE O 5400.5 Chg. 2, "Radiation Protection of the Public and Environment."

Requirements for regulated disposal units are superimposed on institutional control imposed by DOE Order. As an example, post-closure care (Title 40 CFR 264.117-120) of the Pit 3 MWDU will start after certification of closure and consist of three activities: (1) monitoring of moisture in the vadose zone to verify performance of the closure cover, (2) inspecting and maintaining the closure cover to ensure integrity of the cover, and (3) inspecting and maintaining the security of the site (Title 40 CFR 264.117). Post-closure care of the Pit 3 MWDU will be conducted for a minimum of 30 years. Similar activities will likely be specified for other regulated disposal units. For the most part, these activities are coincident with activities of active institutional control.

\subsection{Institutional Control}

Various definitions exist for institutional control. DOE G 435.1-1 defines active institutional control to be a period ". ... when access is controlled, monitoring is performed, and custodial maintenance is performed." In Title 40 CFR 191, the EPA differentiates between active institutional control and passive institutional control. Active institutional control is "(1) Controlling access to a disposal site by any means other than passive institutional control, (2) performing maintenance operations or remedial actions at a site, (3) controlling or cleaning up releases from a site, or (4) monitoring parameters related to disposal system performance." Passive institutional control is "(1) Permanent markers placed at a disposal site; (2) public records and archives; (3) government ownership and regulations regarding land and resource use; and (4) other methods of preserving knowledge about the location, design, and contents of a disposal system." Installation of engineered barriers to control access to a site or disposal unit is another form of passive institutional control. Such barriers will be part of the final closure of GCD boreholes that contain TRU waste (Cochran et al., 2001).

DOE Orders and federal regulations relevant to closure and monitoring of the Area 3 and Area 5 RWMSs provide varying guidance regarding institutional control over these sites. DOE M 435.1-1 specifies that institutional control be continued until the facility can be released pursuant to DOE O 5400.5, "Radiation Protection of the Public and Environment." DOE G 435.1-1 assumes the period of institutional control to be 100 years but adds, consistent with the manual, that after institutional control, “. . . release of a closed disposal facility to unrestricted uses cannot occur until the requirements of DOE O $5400.5 \ldots$ are met." DOE O 5400.5 generally specifies that property may be released for unrestricted use when the effective dose equivalent that could be received by an individual from all pathways associated with that property does not exceed $100 \mathrm{mrem} / \mathrm{yr}$. 


\subsubsection{Active Institutional Control}

Active institutional controls for both the Area 3 and Area 5 RWMSs will be consistent, where appropriate, with in-place or anticipated provisions for the entire NTS and surrounding federal lands (DOE, 2000b,c; 1996). The NNSA/NSO program for active institutional control will include:

(1) Agreements and discussions with the Nellis Air Force Range (also known as the Nellis Test and Training Range), the Bureau of Land Management, the U.S. Fish and Wildlife Service, and the NDEP regarding long-term ownership and control of the lands including and surrounding the NTS. The NNSA/NSO will arrange for provisions that will assure longterm land ownership, stewardship, funding, and control of unauthorized activities where agreements with the above agencies are not possible or forthcoming.

(2) Analysis of existing and potential activities on the NTS lands with the goal of showing how implemented institutional controls will control or prevent unauthorized activities. Existing activities that could continue include scientific research, production of groundwater, excavation for sand and gravel, construction, and serving as corridors for utilities and transportation. Potential activities include ranching, farming, hunting, exploration for hydrocarbons, mining, and illegal or hostile activities such as vandalism, sabotage, and theft.

(3) Commitment to establish and retain the controls for as long as the DOE and the federal government remain viable public entities and are able to maintain ownership and control of the site; that is "in perpetuity" (DOE, 2000b,c).

(4) Maintenance operations, remedial actions, and decommissioning steps necessary to establish the proper post-closure condition for the site.

(5) Monitoring of parameters related to performance of waste disposal systems (BN, 1998a,d).

(6) Implementation of specific controls: (a) fences and signs, (b) facility guards for roadways, and patrols, (c) land-use control and permits, (d) land reclamation, (e) inspection and maintenance, and (f) reporting of activities and incidents that impact access control and security, and any corrective actions.

Most of the above institutional controls are currently ongoing for the NTS or RWMSs, or both. Action (3) above indicates commitment to establish and retain the controls for as long as the DOE and the federal government remain viable public entities and are able to maintain ownership and control of the site; that is, "in perpetuity." The "in perpetuity" commitment warrants separation of controls for the NTS from controls specific to the RWMSs. Subject matter experts gathered to elicit the probability of IHI into a closed waste disposal site in both Frenchman Flat (Area 5 RWMS) and Yucca Flat (Area 3 RWMS) concluded that institutional control will likely not survive in perpetuity. They suggested a maximum duration of 2,000 years, with 90 percent probability that control will be lost within 1,000 years, and 50 percent probability that control 
will be lost within 250 years. The probability of institutional control lasting at least 50 years was suggested by the SMEs to be 90 percent (Black et al., 2001). The probability of active institutional control lasting 100 years then falls at the high end of a range from 50 to 90 percent. According to DOE Orders and federal regulations, the period generally specified for active institutional control over a closed waste disposal site is 100 years.

\subsubsection{Passive Institutional Control}

Beyond 100 years of active institutional controls, passive institutional controls at the disposal sites, such as those defined under Title 40 CFR 191, and institutional controls in place for the NTS are assumed to be sufficient for the RWMSs.

Dates for closure, monitoring, and long-term surveillance and maintenance of the Areas 3 and 5 RWMSs are presented in Section 1.5, Assumptions. Other dates for closure have been used in various related documents (e.g., Shott et al., 1998, 1997, 1995; Cochran et al., 2001), based on programmatic assumptions valid at the time of their development. Both RWMSs will remain open, albeit disposal operations will be considerably reduced for an undetermined period of time. Although many of the institutional controls are currently ongoing and will remain ongoing, active institutional controls shall start the first day of FY 2011 for waste disposal units closed at that time. Within several decades, much of the environmental restoration and waste management activities at the NTS will be concluded or proceeding at a reduced or maintenance level.

Therefore, the continuing work and responsibility for the associated infrastructure are assumed to be transferred to another agency or group within NNSA/NSO that is expecting long-term responsibilities at the NTS. This agency or group is referred to as the NTS Landlord. After transference of the RWMSs to the NTS Landlord, the schedule for closing waste disposal units, and the start of active institutional controls specific to those units, will be determined by the Landlord.

\subsubsection{Unrestricted Release of Sites}

Public access to the NTS is currently restricted and will continue to be restricted as long as the NTS has an active national security mission. An active national security mission is assumed into the foreseeable future. If the NTS national security mission ends, the release of NTS land for public access will be constrained by historical contamination from atmospheric nuclear testing, underground nuclear testing, nuclear rocket testing, and radioactive waste disposal. Remediation and closure of historically contaminated sites on the NTS is regulated by the FFACO (1996) between the NNSA/NSO, the state of Nevada, and the U.S. Department of Defense. The FFACO defines a RCRA-like process for remediation and closure of CAUs and requires the state of Nevada to review and approve all corrective actions. Release of land for public access is also subject to the requirements of DOE O 5400.5, Chg. 2.

The NNSA/NSO has implemented the UGTA Program and the Environmental Restoration Project (Soils Project) to close the UGTAs and contaminated soil sites under the FFACO (1996). The remediation option for UGTA closures, which is accepted by the state, is identification of areas within the NTS where public access or groundwater use will be restricted in perpetuity. 
The dose to a future member of the public who may have access to lands in Frenchman Flat and Yucca Flat has been evaluated in the CAs for the Area 3 and Area 5 RWMSs. Composite Analyses considered all sources of residual radioactive material, assuming that the Soils Sites may not be cleaned up and restricted areas that will be identified by the UGTA program would be in effect, and showed that cumulative dose to a member of the public who resides in Frenchman Flat or Yucca Flat will be below the CA dose limit of $100 \mathrm{mrem} / \mathrm{yr}$ and dose constraint of $30 \mathrm{mrem} / \mathrm{yr}$. Current CAs do not show the extent of the restricted areas. The restricted areas will be incorporated into the CAs under the PA Maintenance Plan when the UGTA Program completes the necessary site characterization and modeling and the boundaries of the restricted areas are agreed between the state of Nevada and the NNSA/NSO. The Corrective Action Decision Document (CADD) identifying the Frenchman Flat UGTA CAU boundaries will be finalized in FY 2008; and the CADD identifying the Yucca Flat boundaries in 2020 .

\subsection{Site Inspection and Maintenance}

Post-closure inspection and maintenance will be minimized to the extent possible by the design of the disposal unit and closure cover system and the additional site security measures that will be in place. The inspection program addresses the inspection requirements for environmental monitoring equipment, fire protection systems, safety and emergency equipment, security devices, and operating or structural equipment that are critical to prevent, detect, or respond to human health or environmental hazards. Records will be used by RWMS personnel for tracking purposes to ensure that inspections are conducted according to established schedules.

Inspections will be each year during the closure periods of institutional control. Inspections will consist of visual observations to ensure that the closure cover's integrity is maintained, and that fencing and boundary monuments are intact. The inspections and associated repairs will ensure that there is protection of human health and environment. The post-closure inspections will include:

- General Facility Inspection: visually inspect fences, gates and locks for breaks, gaps, damage, monuments, missing fence posts, missing gates, ability of gates to properly close and lock, and vegetation.

- Warning Sign Inspection: visibility from at least $8 \mathrm{~m}(25 \mathrm{ft})$ and legibility from $8 \mathrm{~m}(25 \mathrm{ft})$.

- Cover Inspection: observe cover for erosion, settlement, subsidence, displacement, burrowing, and plant growth.

- Run-on/Runoff Inspection: visually inspect control structures and drainage system for presence of erosion and shifting from storms or precipitation.

- Maintenance activities will be based on inspection results. Custodial maintenance or repair actions may include: repair of fences; replacement of warning signs; reestablishment of 
location control monuments; removal of unwanted vegetation; reconstruction of slopes, cover, or embankments.

- The condition of any surveyed subsidence markers will be inspected every six months. In addition, on an annual basis, all survey markers will be resurveyed to determine if the covers have subsided.

- A survey of the boundary monuments regarding their placement, and verification of the condition of each boundary marker, will be performed. Any problems will be noted on the inspection form and repairs made.

- During each inspection, any changes in the condition of the cover, vegetation, or fenced area will be documented.

- Cracks or settling imperfections of 2.5 to $15 \mathrm{~cm}$ (1 to 6 in) deep on the cover will be documented and scheduled for repair on an annual basis. No action will be taken for cracks or settling imperfections of less than $2.5 \mathrm{~cm}$ (1 in). Larger disruptions of the cover (animal diggings or erosion) will be immediately evaluated, repaired, and documented.

All repair work to the cover will ensure that the integrity of the cover and design "as built" is maintained. For RCRA-regulated disposal units, if cover repair requires modifications of the closure cover design, NNSA/NSO will present a formal design modification request to the NDEP prior to making the design modification.

Walkover inspections will be conducted twice a year or when either of the following occurs:

- Precipitation in excess of $1.28 \mathrm{~cm}(0.5 \mathrm{in})$ in a 24 -hour period

- Earthquake with a magnitude exceeding 4.5 on the Richter scale within $100 \mathrm{~km}$ (62 mi) of the site

After five years of post-closure monitoring, the NNSA/NSO may request to reevaluate the monitoring program and/or schedule. An annual summary report of Area 3 and Area 5 RWMSs will include the following information:

- Brief narrative and pictures from post-closure inspection activities

- Cover and subsidence inspection logs

- Moisture content profiles from vadose zone monitors for the previous year

- Maintenance and repair documentation (if any)

- Specific recommendations for non-standard maintenance or changes in post-closure monitoring.

Closure and post-closure monitoring documentation will be maintained in the RWMS files and will be available for inspection and review upon request. 


\subsection{Protection from Adverse Impact}

Protection of the groundwater, human health, and the environment are primary concerns following final closure of the Area 3 and Area 5 RWMSs. The following sections discuss measures to ensure that these resources are not adversely impacted by the facilities.

\subsubsection{Groundwater}

Sections 3.5 and 3.6 include discussions of the geology and hydrology of the sites and how moisture migrates through the unsaturated zone. These sections demonstrate that past, current, and future operations at the RWMSs will not impact the underlying groundwater in the alluvial aquifer. Performance monitoring of the unsaturated zone during the operational phase of the RWMSs has not detected migration of moisture deeper than $2.1 \mathrm{~m}(7 \mathrm{ft})$; no impact to the groundwater has occurred using the current design of the disposal units. During the closure and post-closure phase, the design of the closure cover and drainage system limits infiltration to less than that during operations and prevents water runoff.

No impact to the alluvial aquifer is expected because infiltration will be restricted to the "upward flow region" as specified in Section 3.6. The combination of low precipitation and high potential evapotranspiration induces slow upward migration of moisture within the unsaturated zone from as deep as about $35 \mathrm{~m}(115 \mathrm{ft})$. The average upward velocity of liquid movement is about $0.03 \mathrm{~mm} / \mathrm{yr}(0.0012 \mathrm{in})$. The waste zone and closure cover are in the region of upward flow. Because the depth to groundwater exceeds $488 \mathrm{~m}(1,600 \mathrm{ft})$ at the Area 3 RWMS and $236 \mathrm{~m}$ $(775 \mathrm{ft})$ at the Area $5 \mathrm{RWMS}$, the potential for liquid migration from the disposal units is zero without major climatic changes or catastrophic events.

For regulated disposal units at the Area 5 RWMS, the NDEP had indicated that an exemption from Groundwater Monitoring Requirements during the operational through post-closure care period will be granted based on site-specific information provided in Section 3.6. The approval for granting the exemption during the closure phase is based on (under NAC 444.8632 [incorporating Title 40 CFR 264.90(b)(4)], NNSA/NSO) the following:

- There is no potential migration or releases of liquid from the regulated units to the uppermost aquifer during the active life of the units, including the closure periods, and the post-closure care period under NAC 444.8632 (incorporating Title 40 CFR 264.117);

- The demonstration of no potential migration of liquid is to be certified by a qualified geologist or geotechnical engineer; and

- To provide an adequate margin of safety, any predictions of potential migration of liquid must be made on assumptions that maximize the rate of liquid migration.

The Area 3 and Area 5 RWMSs are located in thick unsaturated alluvial deposits. The hydrological properties of alluvium below the RWMSs have been established through extensive site characterization studies and are summarized in Section 3.6. 
The hydrologic setting of the Area 3 and Area 5 RWMSs is such that the probability of leachate formation or hazardous components from wastes in regulated disposal units reaching groundwater during the active life of the units and the post-closure care period is negligible. This is shown in an evaluation of the unsaturated hydraulic conductivity compared to saturated hydraulic conductivity requirements in the regulations. A low unsaturated hydraulic conductivity of $<10^{-7} \mathrm{~cm} / \mathrm{s}$ is one landfill design criterion for successfully restricting the migration of contaminants. Kearl (1982) provides an unsaturated hydraulic conductivity versus water content chart for alluvial soils at the site. Using an average volumetric-moisture content for the site of 8.7 percent and a soil porosity of 30 percent, the unsaturated hydraulic conductivity for the site soils is approximately $10^{-10} \mathrm{~cm} / \mathrm{s}$ or three orders of magnitude below the regulatory requirement. At depths as shallow as $10 \mathrm{~m}(32.8 \mathrm{ft})$ below the land surface, moisture contents drop below 5 percent, decreasing the unsaturated hydraulic conductivity to less than $10^{-12} \mathrm{~cm} / \mathrm{s}$. Both of these unsaturated conductivities are probably indicative of moisture contents where the interconnection of liquid water ceases, thus preventing the migration of liquids.

Performance monitoring within the closure cover will provide data on the moisture content of soils and the potential for downward or upward movement of liquids By conducting performance monitoring, any potential changes in moisture content will be detected and appropriate remedial measures implemented to prevent continued downward movement of liquid.

NNSA/NSO believes that the extensive modeling simulations have demonstrated that the RCRA Groundwater Monitoring Exemption is warranted. A qualified geologist or geotechnical engineer will certify this exemption request.

\subsubsection{Human Health and Environment}

The Area 3 and Area 5 RWMSs will be monitored and inspected during the closure and postclosure care periods to ensure public safety and human health and prevent damage to the environment. The monolayer-ET closure cover design does not include a barrier against inadvertent human intrusion. The thickness of the cover provides partial protection, since significant effort must be undertaken to expose the waste zone. Site security and long-term institutional control and controlled facility access will prevent human intrusions.

\subsection{Site Security}

Security of the Area 3 and Area 5 RWMSs will continue during the post-closure care period and will include the following:

- Posted warning signs designating site dangers

- Fences to keep out unauthorized personnel

- Controlled site access for specific disposal units

- Perimeter inspections to check for signs of intrusion or fence deterioration/damage

- Overall security at NTS is maintained 24 hours, 7 days a week by highly trained security personnel 


\subsection{Facility Contact}

United States Department of Energy is:

National Nuclear Security Administration

Nevada Site Office

U. S. Department of Energy

Post Office Box 98518

Las Vegas, NV 89193-5818

(702) 295-3211

\subsection{Financial Assurance}

The NTS is a federal facility and is exempt from submission of Financial Assurance documentation according to Title 40 CFR 264.140 (c), [40 CFR 270.14 (b)(15) through (18)]. 


\subsection{MONITORING APPROACH}

The approach to monitoring in this document references many other documents for details of various components of the section. Particularly relevant are (1) the Routine Radiological Environmental Monitoring Program (RREMP) (BN, 2003a) for the decision-based approach to identify key monitoring data that must be collected, and (2) specific monitoring OIs required to maintain consistency and comparability of data from year to year.

\subsection{Introduction}

Monitoring at the Area 3 and Area 5 RWMSs is required under a variety of regulatory drivers, including federal regulations and DOE Orders. Monitoring data are used, in part, to:

- Demonstrate compliance with regulatory drivers

- Confirm PA conceptual models

- Confirm PA assumptions about soil-water contents

- Confirm PA assumptions about flux rates through upward and downward pathways

- Verify the PA performance objective results

- Provide input to the PA maintenance plan

- Evaluate radiation doses to the general public

Monitoring is also conducted to ensure the integrity of covers over waste disposal units. In addition, the monitoring program is designed to sufficiently forewarn management and regulators of any need for mitigative actions, and to record the utility of any mitigative actions.

Monitoring data are required for input to PA maintenance. The maintenance guide for DOE LLW disposal facility PAs and CAs (DOE, 1999b) states the review of results of monitoring and research and development results consist of several activities including:

- Comparing facility monitoring results with expected performance and determining consistency with conceptual models

- Evaluating monitoring results for consistency with CA and conceptual models

- Evaluating other monitoring activities for significant results

- Evaluating research and development results to determine impacts on PA results and conclusions and consistency with conceptual models

- Evaluating research and development results to determine impacts on CA results and conclusions

- Determining if better methodologies or technologies are available

- Evaluating the results of special studies

Review of monitoring data for routine PA and CA maintenance is an iterative process that will ultimately dictate which monitoring data should continue to be collected, and which monitoring data are no longer required. 
At present, direct radiation is continuously monitored at 5 locations within the Area 3 RWMS and 12 locations within the Area 5 RWMS. Air is sampled for tritium at two locations in the prevailing downwind directions near the Area 5 RWMS. Other radionuclides in air are sampled at the same locations in Area 5, as well as four locations at the Area 3 RWMS. Radon flux through waste covers is measured annually at various locations at each RWMS. Vadose zone monitoring for soil-water content and soil-water potential is conducted continuously in waste covers, beneath waste units, and at lysimeter facilities. Surface water runoff is monitored at flumes, and at the floor of a nuclear subsidence crater. Tritium in soil-gas moisture is monitored annually in a deep borehole at the Area 5 RWMS (GCD-05U), which contains a large tritium source. Biota are monitored annually for tritium. Groundwater is currently sampled semiannually at three wells surrounding the Area 5 RWMS for radioactive and nonradioactive constituents, subject to the RCRA groundwater monitoring exemption. In addition, meteorology parameters are continuously monitored at both RWMSs, and measurement of waste cover subsidence is conducted monthly at both RWMSs. A summary of current monitoring activities at the RWMSs is shown in Table 9.1.

\subsection{Quality Assurance, Analysis, and Sampling Plans}

The Quality Assurance, Analysis, and Sampling Plans (QAASPs) specify the sampling, analytical, and quality assurance and quality control procedures for obtaining technically defensible data of acceptable quality to satisfy the project objectives. The QAASP includes guidance for data verification, data validation, and data quality assessment. Detailed QAASPs for air, water, biota, and direct radiation media can be found in Appendices A through D of the RREMP (BN, 2003a).

\subsection{Routine Radiological Environmental Monitoring Plan}

The RREMP (BN, 2003a) brings together sitewide environmental surveillance; site-specific effluent monitoring; and operational monitoring conducted by various missions, programs, and projects on the NTS. The plan provides an approach to identifying and conducting routine radiological monitoring at the NTS, based on integrated technical, scientific, and regulatory compliance data needs. The RREMP uses a decision-based approach to identify the environmental data that must be collected and provides QAASPs which ensure that defensible data are generated. The approach is based on a modification of the EPA's Data Quality Objective (DQO) process (EPA, 1994), a seven-step process that calls for identification of the decisions that data collection activities must support, and uses a logical structure to develop the plan for data collection and analysis. The detailed steps of the process for each media are presented in Appendix E of the RREMP. During the design process, existing and historical site information and regulatory requirements were reviewed. A summary of the site characteristics, transport and exposure pathways, regulatory requirements, and historical data were evaluated for each medium in the preparation of the RREMP to support the monitoring designs. 
Table 9.1 Monitoring activities at the Area 3 and Area 5 Radioactive Waste Management Sites

\begin{tabular}{|c|c|c|}
\hline Monitoring Element & Area 3 RWMS & Area 5 RWMS \\
\hline Direct Radiation Monitoring & $\begin{array}{l}\text { Five thermoluminescent dosimeters } \\
\text { (TLDs) }\end{array}$ & Twelve TLDs \\
\hline Air Monitoring & $\begin{array}{l}\text { Air particulate samples collected at } \\
\text { four locations }\end{array}$ & $\begin{array}{l}\text { Air particulates sampled at two } \\
\text { locations; atmospheric moisture } \\
\text { sampling for tritium at two } \\
\text { locations }\end{array}$ \\
\hline Radon Monitoring & $\begin{array}{l}\text { Radon flux measurements from } \\
\text { waste covers (various locations) }\end{array}$ & $\begin{array}{l}\text { Radon flux measurements from } \\
\text { waste covers (various locations) }\end{array}$ \\
\hline Meteorology Monitoring & $\begin{array}{l}\text { - } \text { air temperature at two heights } \\
\text { - relative humidity at two heights } \\
\text { - wind speed at two heights } \\
\text { - wind direction at two heights } \\
\text { - barometric pressure } \\
\text { - solar radiation } \\
\text { - precipitation }\end{array}$ & $\begin{array}{l}\text { - air temperature at two heights } \\
\text { - relative humidity at two heights } \\
\text { - wind speed at two heights } \\
\text { - wind direction at two heights } \\
\text { - barometric pressure } \\
\text { - solar radiation } \\
\text { - precipitation }\end{array}$ \\
\hline Vadose Zone Monitoring & $\begin{array}{l}\text { - neutron logging for soil-water } \\
\text { content } \\
\text { measurements of soil-water } \\
\text { content and water potential in } \\
\text { waste disposal unit covers } \\
\text { - drainage lysimeter for water } \\
\text { balance since } 2001 \\
\text { - runoff monitoring at a flume and } \\
\text { in a nuclear subsidence crater }\end{array}$ & $\begin{array}{l}\text { - neutron logging for soil-water } \\
\text { content } \\
\text { - measurements of soil-water } \\
\text { content and water potential in } \\
\text { waste disposal unit covers } \\
\text { - measurements of soil-water } \\
\text { content in waste disposal unit } \\
\text { floors } \\
\text { - two weighing lysimeters } \\
\text { (vegetated and bare) for water } \\
\text { balance since } 1994 \\
\text { - runoff monitoring at a flume }\end{array}$ \\
\hline $\begin{array}{l}\text { Soil-gas Moisture Monitoring for } \\
\text { Tritium }\end{array}$ & & $\begin{array}{l}\text { soil-gas moisture sampling for } \\
\text { tritium at nine sampling ports at } \\
\text { depths from } 21 \text { to } 36 \mathrm{~m} \text { ( } 70 \text { to } \\
120 \mathrm{ft}) \text { at GCD-05U }\end{array}$ \\
\hline Biota Monitoring & Sampling vegetation for tritium & Sampling vegetation for tritium \\
\hline Groundwater Monitoring & None & $\begin{array}{l}\text { Three wells sampled semiannually } \\
\text { for RCRA constituents; biennially } \\
\text { for RREMP constituents }\end{array}$ \\
\hline Subsidence Monitoring & $\begin{array}{l}\text { Routine inspections of operational } \\
\text { covers for subsidence features such } \\
\text { as cracks, depressions, ponding, } \\
\text { and erosion }\end{array}$ & $\begin{array}{l}\text { Routine inspections of operational } \\
\text { covers for subsidence features such } \\
\text { as cracks, depressions, ponding, } \\
\text { and erosion }\end{array}$ \\
\hline
\end{tabular}




\subsection{Operational Closure and Post-Closure Monitoring}

Monitoring activities during operational closure and post-closure period of the RWMSs will be based on applicable regulatory drivers and data needs. These activities include:

- Direct radiation monitoring

- Air monitoring

- Tritium monitoring of moisture in soil-gas at GCD-05U

- Vadose zone monitoring of waste covers, waste disposal unit floors, and lysimeter facilities

- Groundwater monitoring

- Biota monitoring

- Subsidence monitoring

- Meteorology monitoring

The decision to continue or terminate any monitoring activities will be based on a routine decision-based approach to identify environmental monitoring data that must continue to be collected during the final closure.

\subsection{Direct Radiation Monitoring}

The objective of direct radiation monitoring is to assess the state of the RWMSs' external radiation environment, detect changes in that environment, and measure gamma radiation levels at the RWMSs and at background locations away from the RWMSs. Direct radiation monitoring is conducted to comply with DOE O 450.1, O 5400.5, and O 435.1, and the Environmental Regulatory Guide for Radiological Effluent Monitoring and Environmental Surveillance (DOE, 1991). Direct radiation monitoring is conducted using TLDs deployed at locations throughout the RWMSs. Five TLDs are deployed at the Area 3 RWMS, and 12 TLDs are deployed at the Area 5 RWMS. Siting of the TLDs was based on a DQO process and described in Appendix E of the RREMP (BN, 2003a).

Figures 9.1, 9.2, and 9.3 show TLD locations at the RWMSs. Annual direct radiation monitoring data are reported in the Annual Waste Management Monitoring Report (BN, 2004b) and the Nevada Test Site Environmental Report (NTSER) (BN, 2004e). The NTSER was formerly called the Annual Site Environmental Report (ASER).

Details of the RWMS direct radiation monitoring activities can be found in the RREMP and Organization Instruction OI-2154.109, "Radiation Monitoring Using Thermoluminescent Dosimeters."

\subsection{Air Monitoring}

The regulatory drivers for the RWMS air monitoring network include Title 40 CFR 61, Subpart H; DOE O 450.1; DOE O 5400.5; and Guidance Document DOE/EH-0173T (DOE, 1991). Details of the DQOs, sampling strategy, field operations, analytical design, analytes, and methods, and quality control checks are described in Appendix A of the RREMP (BN, 2003a). 


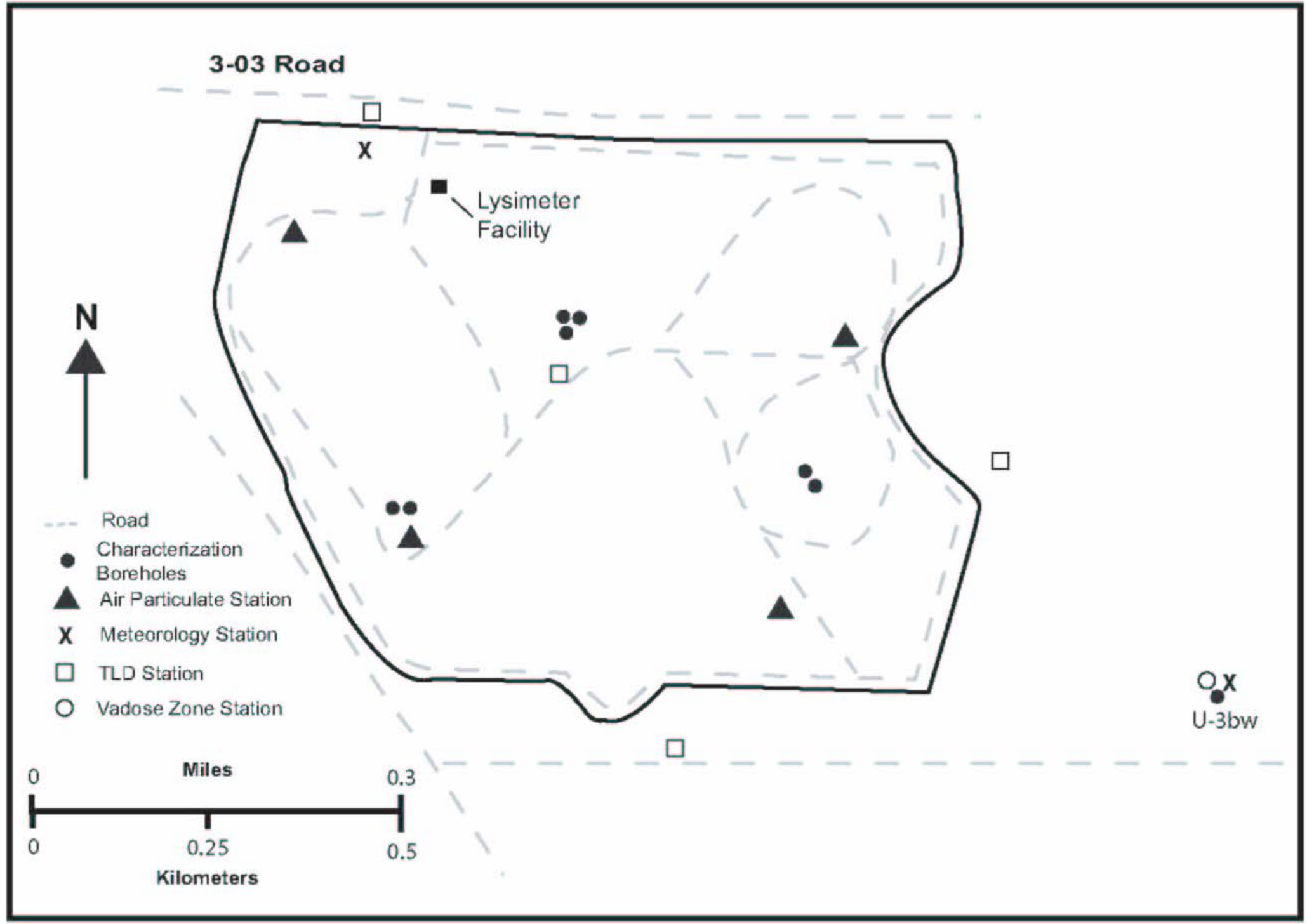

Figure 9.1 Locations and types of monitoring wells at the Area 3 Radioactive Waste Management Site 


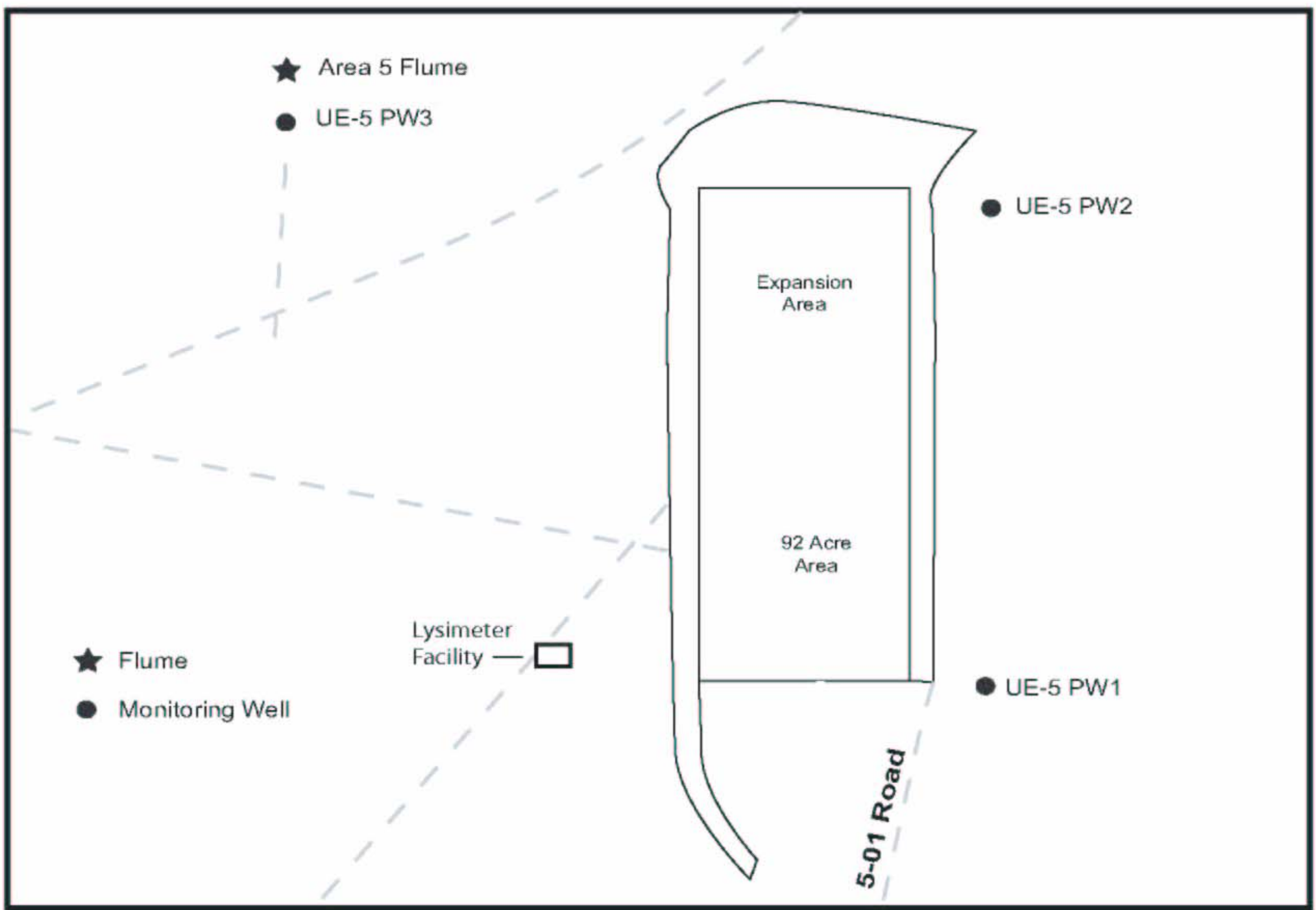

Figure 9.2 Locations of "pilot" monitoring wells, lysimeter facility, and the flume at the Area 5 Radioactive Waste Management Site 


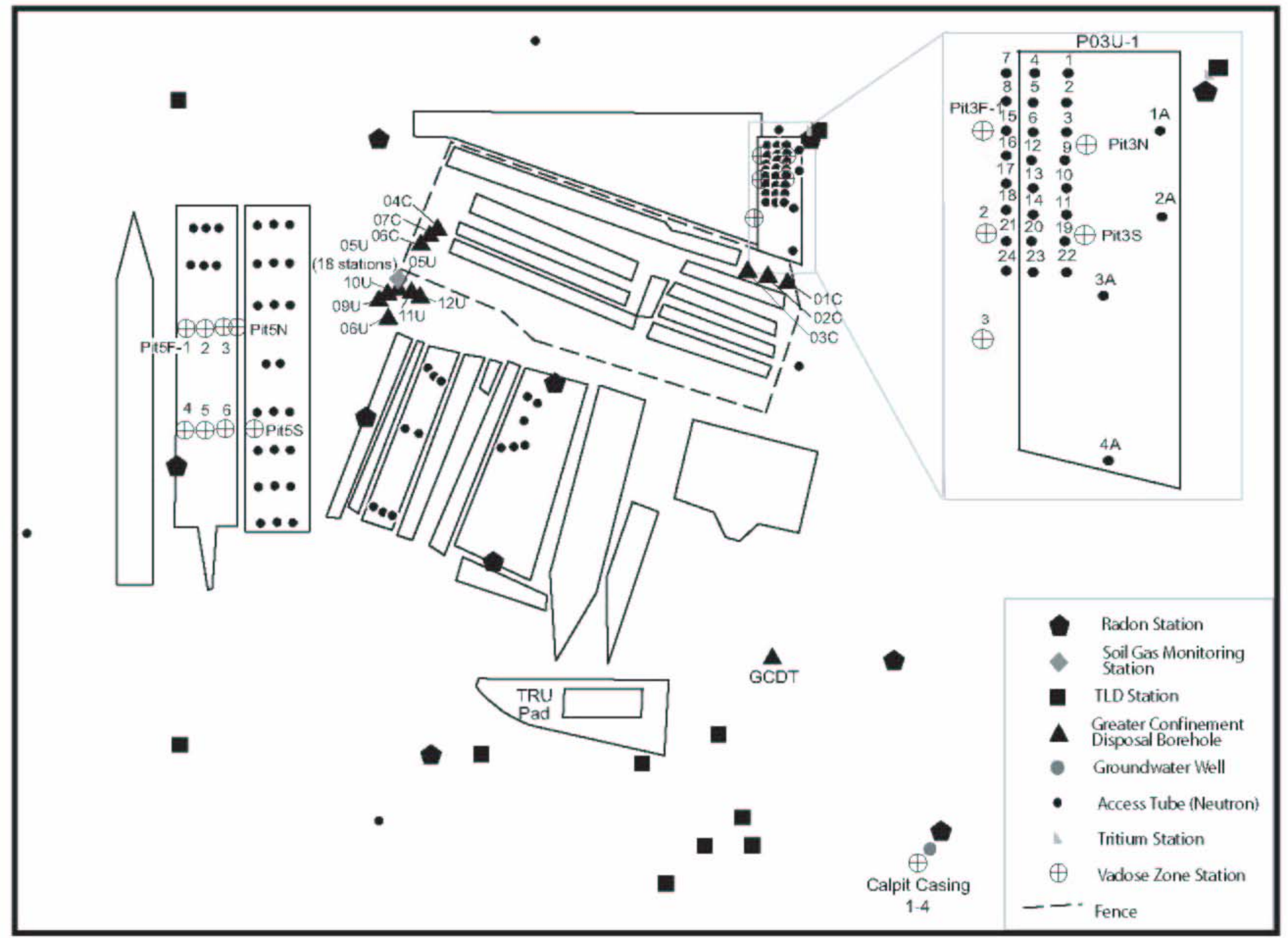

Figure 9.3 Locations and types of monitoring stations at the Area 5 Radioactive Waste Management Site 
Air particulate samples are collected at the RWMSs using continuously operated low-volume air samplers and are analyzed for gross alpha/beta radioactivity, gamma emitters, americium, and plutonium concentrations in air. Atmospheric moisture is collected and analyzed for tritium. Tritium is a volatile radionuclide and is therefore a conservative indicator of waste disposal unit performance.

Air particulate samples are collected at air sampling stations at four locations at the Area 3 RWMS, and two locations near the Area 5 RWMS. Tritium in atmospheric moisture is collected at the Area 5 RWMS at two locations. Atmospheric moisture is not collected at the Area 3 RWMS because of the small tritium inventory. Figures 9.1, 9.2, and 9.3 show locations of air samplers at the RWMSs.

Siting of the air samplers was based on the RREMP DQO process. Important siting decision factors included wind patterns and historic analytical data. In Area 3, wind direction is generally northerly or southerly. Therefore, air sampling stations are sited at locations north and south of each of the active disposal units, U-3ah/at, and U-3bh. In Area 5, air sampling stations (air particulate and tritium samplers) are sited to the north and south of the RWMS.

Annual air monitoring data are reported in the NTSER (e.g., BN, 2004e), the National Emissions Standards for Hazardous Air Pollutants (NESHAP) report (e.g., BN, 2004d), and the Annual Waste Management Monitoring Report (e.g., BN, 2004b).

Details of the RWMS air monitoring activities are in Appendix A of the RREMP (BN, 2003a); Organization Instructions OI-2154.102, "Preparing and Sampling Routine Radiological Environmental Monitoring Plan for Airborne Particulates"; and OI-2154.103, "Tritiated Water Vapor Sampling."

\subsection{Radon Monitoring}

Measurements of radon flux through operational waste covers are conducted at various locations every year using Electret-Passive Environmental Radon Monitors to determine if the fluxes are within a performance objective of $20 \mathrm{pCi} / \mathrm{m}^{2} / \mathrm{s}$ given in the Area 3 and Area 5 PAs and DOE $\mathrm{O}$ 435.1. Radon flux is measured on the cover of $\mathrm{U}-3 \mathrm{ax} / \mathrm{bl}$ because it is the only closed unit at the Area 3 RWMS, and at one or two other waste disposal units per year. For example in FY 2003, radon flux monitoring was conducted on the operational cover of Pit P01U at the Area 5 RWMS and on the cover of U-3ax/bl at the Area 3 RWMS.

Annual radon monitoring data are reported in the Annual Waste Management Monitoring Report (e.g., BN, 2004b). 


\subsection{Vadose Zone Monitoring}

Vadose zone monitoring is conducted at the Area 3 and Area 5 RWMSs to:

- Demonstrate compliance with DOE O 450.1 and O 435.1

- Confirm PA assumptions regarding the hydrologic conceptual model including soil-water contents, and upward and downward flux rates

- Provide added assurance to PA conclusions regarding facility performance

- Test the PA performance objective of protecting groundwater resources

- Demonstrate negligible infiltration of precipitation into zones of buried waste

- Detect changing trends in performance

- Establish baseline levels for long term monitoring

- Comply with NDEP negotiated requirements at Area 3, U-3ax/bl and Area 5, Pit 3 MWDU

Compliance at the RWMSs is achieved by demonstrating that PA assumptions are valid, and that there is negligible infiltration of precipitation into zones of buried waste.

Vadose zone monitoring is conducted by measuring all the water balance components at several locations to account for some spatial variability, and to apply that water balance to an entire RWMS using a concept of surrogate sampling. This type of vadose zone monitoring is not leak detection; it is performance monitoring.

Water balance measurements activities include:

- Meteorological monitoring to measure precipitation (the driving force for downward flow) and to calculate potential evapotranspiration (PET) (the driving force for upward flow)

- Lysimeters (weighing and drainage) to measure infiltration, soil-water redistribution, baresoil evaporation, evapotranspiration, and deep drainage

- Neutron logging through access tubes to measure infiltration, soil-water redistribution, and to monitor specific locations of interest (in some locations to depths of hundreds of feet)

- Automated vadose zone monitoring systems with in situ sensors (TDR probes and heat dissipation [HD] probes) to measure soil-water content and soil-water potential over a large spatial area, but usually to a limited depth

- Surface water runoff monitoring at flumes and at the floor of a nuclear subsidence crater

- Soil-gas sampling for tritium to confirm PA assumptions and transport coefficients

This strategy provides an accurate estimate of the RWMS water balance including any drainage through the RWMS waste covers, and therefore, potential recharge. Based on these data, as well as other work (Tyler et al., 1996), there is essentially no recharge to the groundwater under current conditions at the RWMSs, and all precipitation is effectively returned to the atmosphere by plant transpiration and soil evaporation. 
The current vadose zone monitoring program is designed based on a strong understanding of the vadose zone system from the results of extensive vadose zone characterization studies (BN, 1998c; Blout et al., 1995; REECo, 1994, 1993a,b; Schmeltzer et al., 1996; Shott et al., 1998, 1997, 1995; Tyler et al., 1996), and modeling studies (Crowe et al., 1998b; Levitt et al., 1999). In addition, the vadose zone monitoring program is designed in part from the results of an Alternative Evaluation Study on vadose zone monitoring (BN, 1998d) using an organized team approach, and in part from successful vadose zone monitoring field experience.

Annual vadose zone monitoring data are reported in an annual monitoring report (e.g., BN, 2004b). Details of the RWMS vadose zone monitoring activities can be found in the RWMS vadose zone monitoring Organization Instruction OI-2154.111, "Instructions for Datalogger Monitoring Stations"; OI-2154.106, "Neutron Moisture Logging"; and OI-2154.113, "Soil-gas Sampling at GCD-05U."

\subsubsection{Area 3 Drainage Lysimeter Facility}

A drainage lysimeter facility was constructed adjacent to the northwest corner of the waste disposal unit U-3ax/bl at the Area 3 RWMS. The facility consists of eight drainage lysimeters. Each lysimeter is instrumented with soil-water content and soil-water potential sensors at eight depths. Each lysimeter is $3 \mathrm{~m} \mathrm{(10} \mathrm{ft)} \mathrm{in} \mathrm{diameter,} 2.4 \mathrm{~m}(8 \mathrm{ft})$ deep, and has a sealed bottom that enables direct measurement of drainage. Construction of the facility was funded by the Accelerated Site Technology Deployment program under the DOE Office of Science and Technology. The objective of the facility is to collect data to reduce the uncertainty associated with the performance of monolayer-ET waste covers in arid regions. This uncertainty includes waste cover vegetation type and precipitation amount. The surface treatment of the lysimeters are as follows: two lysimeters were left bare (A and B); two were allowed to revegetate with invader species (C and $\mathrm{D})$; two were revegetated with native species (E and $\mathrm{F}$ ) identical to the revegetation of $\mathrm{U}-3 \mathrm{ax} / \mathrm{bl}$; and two are reserved for future investigations $(\mathrm{G}$ and $\mathrm{H})$, but currently treated like lysimeters $\mathrm{C}$ and $\mathrm{D}$. Lysimeters B, D, F, and $\mathrm{H}$ are irrigated to receive three times the average precipitation.

Data from this facility and data from the U-3ax/bl waste cover monitoring system help assess the performance of future monolayer-ET covers at the Area 3 RWMS. Figure 9.2 shows the location of the Area 3 drainage lysimeter facility.

The Area 3 drainage lysimeter facility is managed by BN Environmental Technical Services (ETS), and any future activities at this site will be managed and coordinated by ETS. For more information of this facility, refer to Dixon et al. (2001) and Levitt and Fitzmaurice (2001).

\subsubsection{Area 5 Weighing Lysimeter Facility}

Two weighing lysimeters were installed about $400 \mathrm{~m}(1,312 \mathrm{ft})$ southwest of the Area 5 RWMS. The lysimeters consist of soil tanks with a volume of $16 \mathrm{~m}^{3}$ (565 cubic feet $\left.\left[\mathrm{ft}^{3}\right]\right)$ mounted on sensitive scales. The top of the soil tank is flush with the ground surface, and access to the side of the soil tank is provided through an underground entry. One lysimeter was revegetated with 
native shrubs, and the other was kept bare to simulate a nonvegetated waste cover. Each weighing lysimeters is instrumented with TDR probes to measure volumetric soil-water content and HD probes to measure soil-water potential at depths ranging from 10 to $170 \mathrm{~cm}$ (4 to $67 \mathrm{in}$ ). The sensitive scale (loadcell) provides extremely accurate measurements of changes of water storage in the lysimeters. For details of the weighing lysimeters, refer to Levitt et al. (1996).

The Area 5 RWMS weighing lysimeter facility has been in continuous operation since March 1994, providing detailed measurements of the surface water balance components including depths of infiltration, soil-water redistrubution, evapotranspiration, bare-soil evaporation, total soil-water storage, and drainage. This facility is considered to be a cornerstone of support for assumptions made in the Area 3 and Area 5 PAs, including confirmation of no downward pathway. In addition, this facility provides data for calibration and verification of flow models, important tools for prediction of radionuclide transport. This facility has also provided data to justify and evaluate the performance of other NTS closure covers (DOE, 2000a,d).

Operation of the Area 5 weighing lysimeter facility will continue to be an important component of the RWMS vadose zone monitoring program by providing detailed water balance data analogous to the water balance of waste covers at the Area 5 RWMS. Figure 9.3 shows the location of the Area 5 weighing lysimeter facility.

The Area 5 weighing lysimeter facility is managed by BN ETS, and any future activities at this site will be managed and coordinated by ETS. For more information on this facility, refer to Levitt et al. (1996).

\subsubsection{Automated Vadose Zone Monitoring Systems}

Installation of automated vadose zone monitoring systems was initiated in 1998 with water

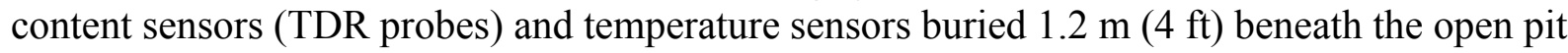
floors of Pit P03U and Pit P05U at the Area 5 RWMS. In 1999, TDR probes were installed in the operational cover of Pit P03U at two locations (Figure 9.3), at depths ranging from 10 to $180 \mathrm{~cm}$ (4 to $71 \mathrm{in}$ ). In 2000, TDR probes and temperature sensors were installed in the operational covers of Pits P04U and P05U at depths ranging from 15 to $180 \mathrm{~cm}$ (6 to $71 \mathrm{in}$ ), and HD probes were installed in the operational cover of Pit P05U at those same depths. Pit P03U floor sensors were discontinued in January 2002.

Time domain reflectometry probes were installed at four locations and eight depths in the $\mathrm{U}-3 \mathrm{ax} / \mathrm{bl}$ waste cover in 2000, as described in the closure plan for U-3ax/bl (DOE, 2000a), and the closure report for $\mathrm{U}-3 \mathrm{ax} / \mathrm{bl}$ (NNSA/NV, 2001). Vadose zone performance monitoring of the waste cover at $\mathrm{U}-3 \mathrm{ax} / \mathrm{bl}$ is required by NDEP for closure of $\mathrm{U} 3 \mathrm{ax} / \mathrm{bl}$, as described in a letter from NDEP to DOE/NV, dated February 22, 2000. Vadose zone monitoring of the U 3ax/bl waste cover is currently administered and conducted by BN Environmental Restoration (ER). All other vadose zone monitoring at the RWMSs is currently administrated and conducted by BN ETS. 
Installation of a vadose zone monitoring system in a waste cover at the Area 3 RWMS other than $\mathrm{U}-3 \mathrm{ax} / \mathrm{bl}$ is unlikely to occur for several years because no other disposal units will be full for several years. Once the U-3bh disposal unit is full, its waste cover may be instrumented with a vadose zone monitoring system. Installation of automated vadose zone monitoring systems at the Area 3 and Area 5 RWMSs will then be complete, although upgrades of system components may be required.

Heat dissipation probes were also installed in the floor of subsidence crater U-3bw to a depth of $4 \mathrm{~m}$ (13 ft) in December 1998 to monitor depths of infiltration following rainfall, and enhanced runoff caused by the geometry of a subsidence crater. In addition, a 3-m (10-ft) meteorology tower and a neutron logging access tube were installed at the floor of U-3bw. Data collected is used to characterize the dynamic water balance of a typical nuclear subsidence crater used for waste disposal at the Area 3 RWMS. These data are required to understand the hydrologic system of a nuclear subsidence crater for waste disposal in Area 3. Refer to Figure 9.2 for the location of U-3bw.

Time-domain reflectometry and other types of automated vadose zone monitoring systems have been implemented at many other study sites with varying degrees of success. Some sites in which TDR or other vadose zone technologies have been used include Beatty, Nevada (Andraski, 1997); Phoenix, Arizona (Young et al., 1999); Albuquerque, New Mexico (Dwyer, 2001; Goering, 1999); Hanford, Washington (DOE, 1999c); and the Savannah River Site (Burns, 1999).

The expected life span of these automated vadose zone monitoring systems is unknown. With routine maintenance and occasional replacement of failed components, these systems should last for years. An additional consideration is that as new and improved vadose zone monitoring sensors and technologies become available, they should be implemented for redundancy or replacement of current systems, wherever appropriate.

\subsubsection{Neutron Logging}

Neutron logging is currently conducted at selected neutron access tubes at the Area 3 and Area 5 RWMSs to provide profiles of soil-water content with depth and time. The automated vadose zone monitoring systems at the RWMSs have largely replaced neutron logging. Use of infrequent neutron logging may be useful to supplement automated vadose zone systems where access tubes remain accessible. No neutron access tubes are anticipated to remain in the covers. Figures 9.2 and 9.3 show locations of all neutron logging access tubes at the RWMSs.

At the Area 3 RWMS, deep vadose zone monitoring by neutron logging has been conducted in cased boreholes angled under the U 3ah/at and U-3ax/bl disposal units, and in cased boreholes drilled directly into the floor of the $\mathrm{U} 3 \mathrm{bh}$ disposal unit. These boreholes are designated U-3at-D1, U-3at-D2, U-3bh-C1, U-3bh-C2, U-3b1-D1, U-3bl-D2, and U-3bl-U1.

At the Area 5 RWMS, neutron logging has been conducted in access tubes penetrating the 2.4-m- (8-ft)-thick operational covers. Neutron access tubes for routine monitoring were 
selected based on data history, tube integrity, and to provide a representative area of wide spatial coverage. Area 5 RWMS access tubes provide data on the near-surface water balance, but Area 3 RWMS access tubes provide data only on changes in water contents at depth greater than about $3 \mathrm{~m}(10 \mathrm{ft})$ due to the presence of thick surface casings and cement structures that cannot be logged with accuracy.

\subsubsection{Soil-gas Monitoring for Tritium}

Tritium monitoring of moisture in soil-gas is conducted to evaluate the upward pathway for radionuclide transport. Tritium is a volatile radionuclide that provides a conservative measure of the performance of the waste site and its ability to isolate buried waste.

Tritium monitoring of moisture in soil-gas is conducted by sampling at GCD-05U, a GCD unit with a large tritium inventory $(2.2$ million $\mathrm{Ci}$ at time of disposal) located near the center of the Area 5 RWMS, which is instrumented with a string of nine gas sampling ports buried at depths of 21 to $37 \mathrm{~m}$ (70 to $120 \mathrm{ft}$ ). Tritium sampling at GCD-05U provides a measure of tritium migration from waste packages with time because of degradation of waste containers and natural transport processes. Tritium sampling at GCD-05U has been conducted every year since 1990, providing an important data set for analyzing tritium migration from the Area 5 RWMS.

Figure 9.3 shows the location of GCD-05U at the Area 5 RWMS.

Soil-gas sampling ports are also located in various locations at the Area 5 RWMS including several locations beneath pits P03U and P05U. The ports are not currently monitored, but if required, they may be monitored in the future to augment current studies of tritium migration.

\subsection{Biota Monitoring}

On January 15, 2003, DOE O 450.1, "Environmental Protection Program," was approved. This new Order replaced DOE O 5400.1 and added specific requirements for the protection of other natural resources including biota, and to evaluate the potential impacts to biota in the vicinity of DOE activities. To demonstrate compliance with these requirements, a DOE technical standard, "A Graded Approach for Evaluating Radiation Doses to Aquatic and Terrestrial Biota" (DOESTD-1153-2002) was developed by the DOE's Biota Dose Assessment Committee. This standard describes a graded approach for evaluating radiation doses to biota and set the following dose limits that, based on current scientific understanding, are protective of populations of biota:

- $\quad$ Dose limit to aquatic animals $=1 \mathrm{rad} /$ day $(10 \mathrm{mGy} /$ day $)$

- Dose limit to terrestrial plants $=1 \mathrm{rad} /$ day $(10 \mathrm{mGy} /$ day $)$

- Dose limit to terrestrial animals $=0.1 \mathrm{rad} /$ day $(1 \mathrm{mGy} / \mathrm{day})$

Monitoring of radionuclides in biota are done to evaluate potential dose to biota, potential dose to humans consuming game animals and to evaluate the possible transport of radionuclides from waste disposal areas. 
At the RWMSs, biota monitoring consists of sampling vegetation for analyses including tritium, gamma-emitting radionuclides, and transuranics. If radionuclide concentrations in vegetation are high, other wild game animals may be sampled. Vegetation sampling may be limited year to year, depending on rainfall and waste cover operations during operational closure. Vegetation from on and near waste covers, as well as vegetation from control areas far from waste covers, are sampled in mid-summer each year and analyzed for tritium. Timing of the sampling is important because vegetation is forced to remove soil-water from greater depths (closer to waste) as surface soils dry out in summer. Plant water is extracted from the vegetation samples by room temperature vacuum distillation and analyzed by liquid scintillation for tritium. Animals (and soil from animal burrows) will be monitored for radionuclides if warranted by increasing tritium concentration trends in vegetation, or if animal burrows on or near waste covers are observed in significant numbers.

Slightly elevated tritium concentrations in air and vegetation at the Area 5 RWMS indicate that there is an upward pathway for tritium migration primarily because of the combined effects of diffusion and plant transpiration processes. Therefore, this pathway should continue to be monitored.

Annual biota monitoring data are reported in the NTSER (e.g., BN, 2004e) and in the Annual Waste Management Monitoring Report (e.g., BN, 2004b). Details of the RWMS biota monitoring activities can be found in the RWMS biota monitoring Organization Instruction OI-2154.110 "Biota Sampling and Sample Preparation for Animals and Vegetation."

\subsection{Surface Water Runoff Monitoring}

Design of structures and closure covers that can best accommodate run-on from precipitation events over long periods of time must rely on historical precipitation and discharge data. Precipitation data have been collected at various locations around the NTS for several decades. However, until recently, the locations of data collection were not proximal to middle reaches of watersheds that potentially collect and discharge waters to the vicinities of facilities. To collect precipitation and discharge data relevant to performance assessment and eventual design activities, two each of precipitation gauges and flumes have been installed in watershed channels near the Area 3 and Area 5 RWMSs. One precipitation gauge and flume is located in a watershed channel east of the Area 3 RWMS and the other is located in a watershed channel northwest of the Area 5 RWMS. Refer to Figures 9.4 and 9.1 for the locations of the Area 3 and Area 5 flumes, respectively. The flume in Area 3 was installed in FY 1999 and the flume in Area 5 was installed in FY 2000. The intent is to collect precipitation and discharge data at these locations through FY 2007, after which, activities associated with final closure of the currently active, 92-ac part of the Area 5 RWMS will be initiated.

\subsection{Groundwater Monitoring}

Groundwater monitoring is not currently conducted at the Area 3 RWMS. Mixed waste disposal unit U-3ax/bl requires groundwater monitoring under Title 40 CFR 264. However, a 
Integrated Closure and Monitoring Plan

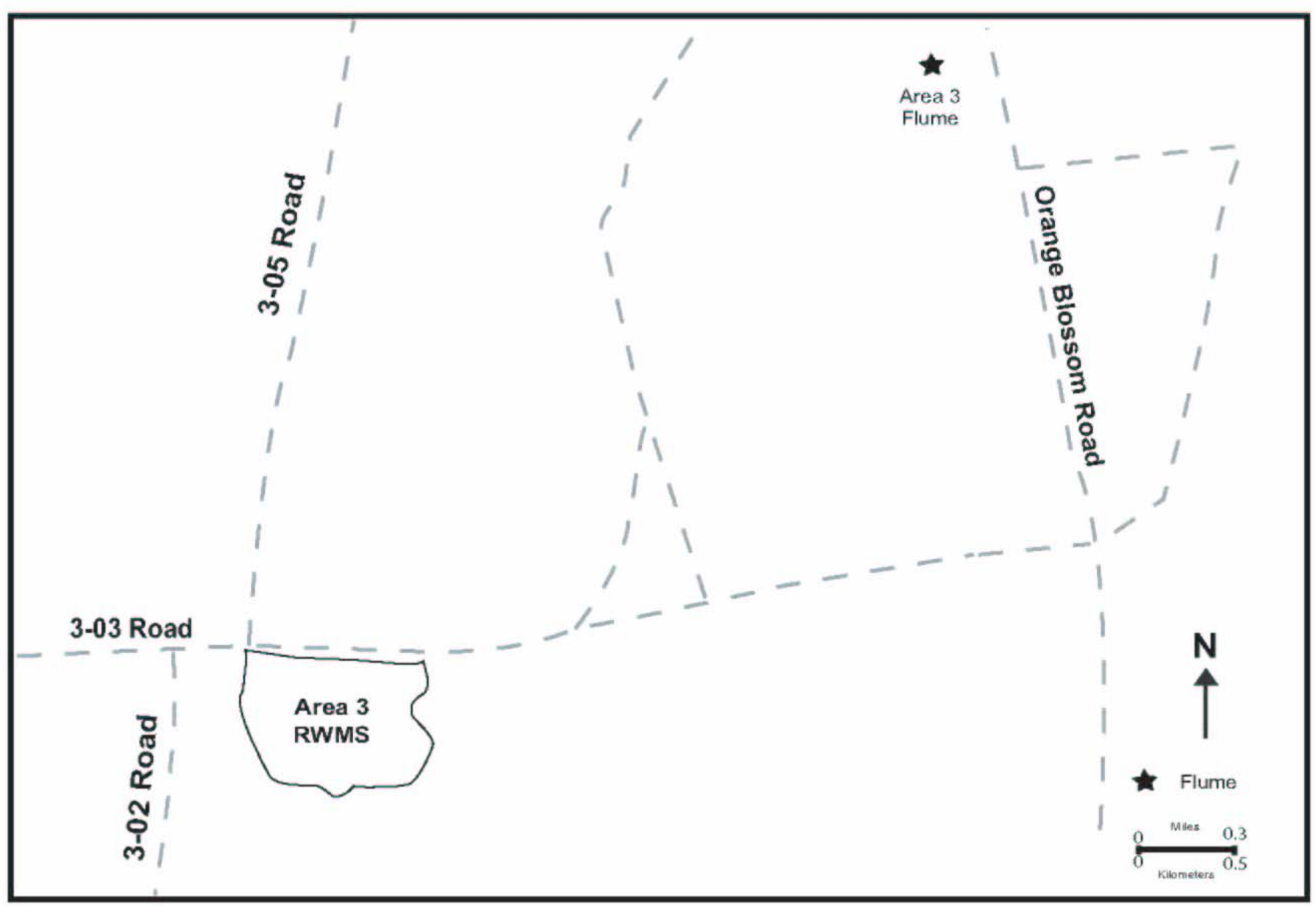

Figure 9.4 Locations of flume at the Area 3 Radioactive Waste Management Site 
groundwater monitoring exemption has been approved by NDEP which waives the requirements of groundwater monitoring under Title 40 CFR 264 at the Area 3 RWMS.

Groundwater monitoring is conducted at the three pilot wells surrounding the Area 5 RWMS (Figure 9.1) as required by Title 40 CFR 265. These wells were originally drilled in 1993 as characterization wells for determination of physical and chemical properties of drill core, for determination of chemical properties of groundwater in the uppermost aquifer, and for determination of depths to the uppermost aquifer. In a letter from DOE/NV to NDEP dated December 12, 1993, DOE/NV requested that the pilot wells be accepted as RCRA monitoring wells. In a letter from NDEP to DOE/NV, dated February 24, 1994, NDEP stated that the pilot wells appear to meet the applicable design, construction, and development criteria for RCRA groundwater monitoring wells. A revised groundwater monitoring program outline was submitted to NDEP on March 1, 1998 (BN, 1998a). On March 31, 1998, NDEP transmitted a letter to DOE stating concurrence with the sampling frequency, indicator parameters, and investigation levels submitted in the groundwater monitoring outline.

Groundwater from pilot wells is sampled semiannually for the following parameters (BN, 1998a):

Indicators of Contamination:

- $\mathrm{pH}$

- specific conductance

- total organic carbon

- total organic halogen

- tritium

General Water Chemistry Parameters:

- total $\mathrm{Ca}, \mathrm{Fe}, \mathrm{Mg}, \mathrm{Mn}, \mathrm{K}, \mathrm{Na}, \mathrm{SiO}_{2}$

- total $\mathrm{SO}_{4}, \mathrm{Cl}, \mathrm{F}$

- alkalinity

Investigation levels for these indicators of contamination can be found in BN (1998a). Details of pilot well construction can be found in BN (2004a).

Additional groundwater monitoring requirements were driven by DOE Orders and, independent of EPA requirements, were determined through a DQO-driven process and are detailed in the RREMP (BN, 2003a). Groundwater monitoring analytes identified in the RREMP include:

- tritium

- gross alpha

- gross beta 
- gamma spectroscopy

- plutonium-238 and plutonium-239+240

The groundwater monitoring frequency identified in the RREMP is biennial. All groundwater sampling data from the Area 5 RWMS pilot wells to date indicate that the groundwater in the uppermost aquifer has not been affected by RWMS or past weapons testing activities. Tritium concentrations in the groundwater beneath the Area 5 RWMS have never exceeded the method detection limit (MDL) for enriched tritium analysis (approximately $15 \mathrm{pCi} / \mathrm{L}$ ). Groundwater elevation data indicate that the water table beneath the Area 5 RWMS is nearly flat, with groundwater flowing in a northeastern direction at a horizontal velocity of approximately $23 \mathrm{~cm}$ (9 in) per year (BN, 2004a).

Groundwater monitoring data are presented in detail in the annual groundwater monitoring data report (e.g., BN, 2004a). Details of the Area 5 RWMS groundwater monitoring activities can be found in Appendix B of the RREMP (BN, 2003a) and the Area 5 RWMS groundwater monitoring Organization Instructions OI-2154.108, "Instructions for Area 5 RWMS Groundwater Well Preparation and Groundwater Sampling"; and OI-2154-104, "Preparing and Sampling Routine Radiological Environmental Monitoring Plan (RREMP) Groundwater Wells."

\subsection{Meteorology Monitoring}

A meteorology monitoring program is maintained by operating one two-level meteorology tower at each RWMS. In addition to fulfilling basic regulatory requirements for meteorology monitoring in DOE O 450.1, the RWMS meteorology monitoring program is designed to include measurements of components of the surface energy balance for calculation of PET using the Penman equation (Doorenbos and Pruitt, 1997). PET calculations are an important component of the water balance estimates of the RWMSs.

Meteorological parameters monitored at the RWMSs include:

- Air temperature at two heights

- Relative humidity at two heights

- Wind speed at two heights

- Wind direction at two heights

- Barometric pressure

- Solar radiation

- Precipitation

Figures 9.2 and 9.3 show locations of meteorology monitoring stations at the Area 3 and Area 5 RWMSs.

Annual meteorology monitoring data are reported in an annual monitoring report (e.g., BN, 2004b). Details of the RWMS meteorology monitoring activities can be found in the RWMS meteorology monitoring Organization Instruction OI-2154.111, "Instructions for Datalogger Monitoring Stations." 


\subsection{Subsidence Monitoring}

Subsidence monitoring consists of routine inspections of operational and final waste covers for subsidence features such as cracks and depressions, ponding, and erosion. When such features are observed, their locations are recorded using a Global Positioning System unit and digital camera, and operations personnel are informed to take corrective action.

$\mathrm{U}-3 \mathrm{ax} / \mathrm{b}$ is the only disposal unit at the Area 3 RWMS that is closed. Subsidence monitoring of $\mathrm{U}-3 \mathrm{ax} / \mathrm{bl}$ is currently conducted by BN ER as required by agreement with NDEP.

At the Area 3 RWMS, subsidence monitoring is conducted monthly at disposal units U-3bh and U-3ah/at where waste is buried to ensure that waste remains covered.

At the Area 5 RWMS, subsidence monitoring is conducted monthly at all operationally closed disposal units and at partially buried disposal units.

Details of the RWMS subsidence monitoring activities can be found in an annual monitoring report (e.g., BN, 2004b), and the RWMS subsidence monitoring Organization Instruction OI-2154.112, "Subsidence Monitoring at the Radioactive Waste Management Sites." The effectiveness of subsidence monitoring will be periodically evaluated.

\subsection{Monitoring During Active Institutional Control}

Monitoring activities during the active institutional control of the RWMSs are expected to be reduced and limited to:

- Air monitoring for atmospheric tritium

- Tritium monitoring of moisture in soil-gas at GCD-05U

- Vadose zone monitoring of waste covers, waste disposal unit floors, and lysimeter facilities

- Groundwater monitoring

- Biota monitoring for tritium

- Subsidence monitoring

The decision to continue or terminate any monitoring activities will be based on a routine decision-based approach to identify environmental monitoring data that must continue to be collected during the final closure and active institutional control periods.

Air monitoring for radionuclides (other than for radon and atmospheric tritium) will be discontinued during final closure and the institutional control period because the primary mechanism for transport of airborne radionuclides other than radon and tritium is from open pits in which waste is directly exposed to the atmosphere. Once waste is buried, air monitoring for radionuclides other than radon and tritium is not required. Radon concentrations in air and radon flux from waste units will continue to be monitored during the final closure and active institutional control period because radon concentration limits are specific performance objectives. 
Tritium in atmospheric moisture will continue to be monitored during final closure and active institutional control period because tritium is an important indicator of waste disposal unit performance.

Groundwater monitoring for RCRA constituents and compliance with Title 40 CFR 264 and 265 will be discontinued when a groundwater monitoring exemption is requested from, and approved by, NDEP. However, groundwater monitoring may continue at the Area 5 RWMS pilot wells under the RREMP program.

\subsection{Monitoring During Passive Institutional Control}

No monitoring will be conducted during the passive institutional control period.

\subsection{Data Management}

All RWMS monitoring data are archived in BN's data management system, Bechtel Environmental Integrated Data Management System (BEIDMS). BEIDMS is an Oracle TM $_{-}$based relational database management system developed by BN for the comprehensive management and processing of environmental data. This database management system has been licensed and tailored to support both small and large environmental projects at BN. BEIDMS will ensure consistency and promote advanced planning, while providing a central repository for all unclassified environmental data.

\subsection{Data Evaluation and Data Reporting}

Evaluation of all monitoring data is conducted once per year, at minimum, and conclusions of those evaluations are incorporated into one or all of the applicable annual data reports including the NTSER (e.g., BN, 2004e); the NESHAP report (e.g., BN, 2004d); the Annual Groundwater Monitoring Report (e.g., BN, 2004a); and the Annual Waste Management Monitoring Report (e.g., BN, 2004b).

The BN Organization Procedures (Ops)/OIs required for preparation of the NESHAP report and NTSER (ASER) include:

- OI-2154.105, "Development of the Annual National Emission Standards for Hazardous Air Pollutants (NESHAP) Report for the NTS and Offsite Dose Assessment"

- OP-2154.109, "Investigation of Facilities for National Emissions Standards for Hazardous Air Pollutants Compliance"

- OP-2154.110, "Preparation of the Annual Site Environmental Report (ASER)" 


\subsection{Organizational Instructions}

The OIs required for routine monitoring of the RWMSs include:

- OI-2154.108, "Instructions for Area 5 RWMS Groundwater Well Preparation and Groundwater Sampling"

- OI-2154.102, "Preparing and Sampling Routine Radiological Environmental Monitoring Plan for Airborne Particulates"

- OI-2154.103, "Tritiated Water Vapor Sampling”

- OI-2154.104, "Preparing and Sampling Routine Radiological Environmental Monitoring Plan (RREMP) Groundwater Wells"

- OI-2154.106, "Neutron Moisture Logging"

- OI-2154.107, "Radon Monitoring Using the E-PERM System"

- OI-2154.109, "Radiation Monitoring Using Thermoluminescent Dosimeters"

- OI-2154.110, "Biota Sampling and Sample Preparation for Animals and Vegetation"

- OI-2154.111, "Instructions for Datalogger Monitoring Stations"

- OI-2154.112, "Subsidence Monitoring at the Radioactive Waste Management Sites"

- OI-2154.113, "Soil-gas Sampling at GCD-05U" 


\subsection{REFERENCES}

Allred, D. M., D. M. Beck, and C. D. Jorgensen, 1963. "Biotic Communities of the Nevada Test Site.” Brigham Young University Science Bulletin, Biological Series 2(2), No. 2.

Andraski, B. J., 1997. "Soil-Water Movement Under Natural-Site and Waste-Site Conditions: A Multiple-Year Field Study in the Mojave Desert, Nevada." Water Resources Research 33(8):1901-1916.

Barker, L., 1997. Alternative Evaluation Study: Methods to Mitigate/Accommodate Subsidence for the Radioactive Waste Management Sites at the Nevada Test Site, Nye County, Nevada, with Special Focus on Disposal Unit U-3ax/bl. Bechtel Nevada, September 1997.

Battis, J. D., 1978. Geophysical Studies for Missile Basin; Seismic Risk Studies in the Western United States. TI-ALEX(02)-FSR-78-01. Texas Instruments, Inc., Houston, Texas.

Beatley, J. C., 1976. Vascular Plants of the Nevada Test Site and Central-Southern Nevada; Ecology and Geographic Distributions. TID-26881. U.S. Energy Research and Development Administration, Division of Biomedical and Environmental Research.

BN (Bechtel Nevada), 2005. Written Communication prepared for NNSA/NSO. Subject: $A$ Hydrostratigraphic Model and Alternatives for the Groundwater Flow and Contaminant Transport Model of Corrective Action Unit 98: Frenchman Flat, Nye County, Nevada. Las Vegas, Nevada.

, 2004a. Nevada Test Site 2003 Data Report: Groundwater Monitoring Program, Area 5 Radioactive Waste Management Site. DOE/NV/11718--894. Report to U.S. Department of Energy, National Nuclear Security Administration Nevada Site Office, Las Vegas, Nevada. February 2004.

—, 2004b. Nevada Test Site 2003 Waste Management Monitoring Report: Area 3 and Area 5 Radioactive Waste Management Sites, Nevada Test Site. DOE/NV/11718--930. Report to U.S. Department of Energy, National Nuclear Security Administration Nevada Site Office, Las Vegas, Nevada. June 2004. , 2004c. Written Communication prepared for NNSA/NSO.

Subject: 2003 Annual Summary Report for the Area 3 and Area 5 Radioactive Waste Management Sites at the Nevada Test Site Nye County, Nevada. Bechtel Nevada, Las Vegas, Nevada. January 2004.

, 2004d. National Emissions Standards for Hazardous Air Pollutants Calendar Year 2003 DOE/NV/11718--929. Report to U.S. Department of Energy, National Nuclear Security Administration Nevada Site Office, Las Vegas, Nevada. June 2004. 
2004e. Nevada Test Site Environmental Report 2003. DOE/NV/11718--971. Report to U.S. Department of Energy, National Nuclear Security Administration Nevada Site Office, Las Vegas, Nevada. October 2004.

—_, 2003a. Nevada Test Site Routine Radiological Environmental Monitoring Plan. DOE/NV/11718--804. Report to U.S. Department of Energy, National Nuclear Security Administration Nevada Site Office, Las Vegas, Nevada. June 2003.

- 2002. Characterization Report, Operational Covers for the Area 5 Radioactive Waste Management Site at the Nevada Test Site. DOE/NV/11718--758. Report to U.S. Department of Energy, National Nuclear Security Administration, Nevada Operations Office, Las Vegas, Nevada. September 2002

— 2001a. Addendum 1 Performance Assessment for the Area 5 Radioactive Waste Management Site at the Nevada Test Site, Nye County, Nevada, Reevaluation of the Chronic Inadvertent Human Intrusion Scenarios to Resolve the Disposal Authorization Statement Issues. DOE/NV/11718--176-ADD1. Report to U.S. Department of Energy, National Nuclear Security Administration, Nevada Operations Office, Las Vegas, Nevada. November 2001.

,2001b. Addendum 1 Composite Analysis for the Area 5 Radioactive Waste Management Site at the Nevada Test Site, Nye County, Nevada. DOE/NV/--594-ADD1. Report to U.S. Department of Energy, National Nuclear Security Administration, Nevada Operations Office, Las Vegas, Nevada. November 2001.

, 1999. Characterization Report for Corrective Action Unit 110: Area 3 U-3ax/bl Disposal Unit Nevada Test Site, Nevada. DOE/NV--580. Report to U.S. Department of Energy, Nevada Operations Office, Las Vegas, Nevada. Environmental Restoration Division, Bechtel Nevada. November 1999.

, 1998a. Revised Area 5 Radioactive Waste Management Site, Outline of a Comprehensive Groundwater Monitoring Program. Report to U.S. Department of Energy, Nevada Operations Office, Las Vegas, Nevada. February 1998.

1998b. Geology Report, Area 3 Radioactive Waste Management Site, Nye County, Nevada. DOE/NV/11718--195. Report to U.S. Department of Energy, Nevada Operations Office, Las Vegas, Nevada. January 1998.

, 1998c. Hydrogeologic Characterization of the Unsaturated Zone at the Area 3 Radioactive Waste Management Site. Volume 1: Data Interpretations. Volume 2: Data. DOE/NV/11718--210. Bechtel Nevada, February 1998. 
, 1998d. Alternative Evaluation Study: Implementing Vadose Zone Monitoring at the Nevada Test Site-Issues Common to All Environmental Programs and Issues Unique to Radioactive Waste Management Sites, November 3-4, 1997. Report to U.S. Department of Energy, Nevada Operations Office, Las Vegas, Nevada. January 1998.

Black, P., K. Black, L. Stahl, M. Hooten, T. Stockton, and D. Neptune, 2001. Assessing the Probability of Inadvertent Human Intrusion at the Nevada Test Site Radioactive Waste Management Sites. DOE/NV--593. Report to U.S. Department of Energy, Nevada Operations Office, March 2001.

Blout, D. O., W. S. Birchfiel, D. P. Hammermeister, K. A. Zukosky, and K. D. Donnelson, 1995. Site Characterization Data from Area 5 Science Boreholes, NTS, Nye County, Nevada. DOE/NV/11432-170. Reynolds Electrical \& Engineering Co., Inc. February 1995.

Brosseau, D. A., 2001. Compliance Assessment Document for the Transuranic Waste in the Greater Confinement Disposal Boreholes at the Nevada Test Site. Volume 4: Application of Assurance Requirements (Version 2.0). Sandia Report SAND2001-2945. Sandia National Laboratories. September 2001.

Burns, H. H., 1999. "Vadose Zone Monitoring System for the Savannah River Site Low-Level Radioactive Waste Disposal Trenches." 11th Technical Information Exchange Conference, October 26-28, 1999, Las Vegas, Nevada.

Campbell, K. W., 1980. Seismic Hazard Analysis for the Nevada Test Site Spent Reactor Fuel Test Site. UCRL-15620. Lawrence Livermore Laboratory, Livermore, California.

Case, C., J. Davis, R. French, and S. Raker, 1984. "Site Characterization in Connection With the Low-Level Defense Waste Management Site in Area 5 of the Nevada Test Site, Nye County, Nevada - Final Report.” Desert Research Institute Publication No. 45034, Las Vegas, Nevada.

Castor, S. B., S. C. Feldman, and T. J. Vingley, 1990. Mineral Evaluation of the Yucca Mountain Addition, Nye County, Nevada. Open-File Report 90-4, Nevada Bureau of Mines and Geology, Reno, Nevada.

CFR (Code of Federal Regulations). Title 40 CFR 61, "National Emission Standards for Hazardous Air Pollutants.” Revised July 1, 1996.

2. Title 40 CFR 191, "Environmental Radiation Protection Standards for Management and Disposal of Spent Nuclear Fuel, High-Level and Transuranic Radioactive Wastes," 1996.

. Title 40 CFR 264, "Standards for Owners and Operators of Hazardous Waste Treatment, Storage, and Disposal Facilities," 1996. 
. Title 40 CFR 265, "Interim Status Standards for Owners and Operators of Hazardous Waste Treatment, Storage, and Disposal Facilities," 1996.

Chapman, J. B., 1994. Classification of Groundwater at the Nevada Test Site. DOE/NV/10845--16. Desert Research Institute, Las Vegas, Nevada.

Cochran, J. R., W. E. Beyeler, D. A. Brosseau, L. H. Brush, T. J. Brown, S. H. Conrad, P. A. Davis, T. Ehrhorn, T. Feeney, B. Fogleman, D. P. Gallegos, R. Haaker, D. Kalinina, L. L. Price, D. P. Thomas, and S. Wirth, 2001. Compliance Assessment for the Transuranic Wastes in the Greater Confinement Disposal Boreholes at the Nevada Test Site. Volume 2: Performance Assessment (Version 2.0). Sandia Report SAND2001-2977. Sandia National Laboratories. September 2001.

Cole, J. C., R. R. Wahl, and M. R. Hudson, 1989. "Structural Relations Within the Paleozoic Basement of Mine Mountain Block; Implications for Interpretation of Gravity Data in Yucca Flat, Nevada Test Site." In: C. W. Olsen and J. A. Carter (eds.), Proceedings of the Fifth Symposium on Containment of Underground Nuclear Explosions. Lawrence Livermore National Laboratory Proceedings, CONF-850953, p. 431-456.

Crowe, B. M., 2004. Written communication to D. Tobiason. Conceptual Model of the Unsaturated Zone: Area 5 RWMC and Conceptual Model of Shallow Land Burial at the Area 5 RWMS. September 2004.

Crowe, B. M., P. Wallmann, and L. M. Bowker, 1998a. "Probabilistic Modeling of Volcanism Data: Final Volcanic Hazard Studies for the Yucca Mountain Site.” In: Perry, F., B. M. Crowe, G. A. Valentine, J. Geissman, L. McFadden, S. Wells, M. Murrell, J. Poths, and L. Bowker, Volcanism Synthesis Report. Los Alamos National Laboratory, Los Alamos, New Mexico.

Crowe, B., W. Hansen, R. Waters, M. Sully, and D. Levitt, 1998b. The Consequences of Disposal of Low-level Radioactive Waste from the Fernald Environmental Management Project: Report of the DOE/Nevada Independent Panel. LA-13453-MS. Los Alamos National Laboratory, Los Alamos, New Mexico.

Crowe, B. M., 1990. "Basaltic Episodes of the Yucca Mountain Region." In: Proceedings, High-level Radioactive Waste Management, International Conference, Las Vegas, Nevada. American Nuclear Society, La Grange, Illinois, p.65-73.

Crowe, B. M., M. T. Vaniman, and W. J., Carr, 1983. Status of Volcanic Hazard Studies for the Nevada Nuclear Waste Storage Investigation. LA-9325-MS. Los Alamos National Laboratory, Los Alamos, New Mexico.

Dickman, P. T., A. T. Vollmer, and P. H. Hunter, 1984. Operational Technology for Greater Confinement Disposal. DOE/NV/10327--14. December 1984. 
Dixon, J. M., D. G. Levitt, and S. E. Rawlinson, 2001. Alternative Site Technology DeploymentMonitoring System for the U-3ax/bl Disposal Unit at the Nevada Test Site.

DOE/NV/11718--505. 36th Annual Engineering Geology and Geotechnical Engineering Symposium: Soil and Water Issues for the Arid West, March 28-30, 2001, Las Vegas, Nevada.

Dockery-Ander, H. A., 1984. Rotation of Late Cenozoic Extensional Stress, Yucca Flat Region, Nevada Test Site, Nevada. Ph.D. dissertation. Rice University, Houston, Texas.

DOE (U.S. Department of Energy), 2000a. Closure Plan for Corrective Action Unit 110: Area 3 RWMS U-3ax/bl Disposal Site, Nevada Test Site, Nevada. DOE/NV--647. Environmental Restoration. August 2000.

—, 2000b. Written Communication. Subject: FY 2000 Long-Term Stewardship Report, Nevada Test Site (Revision 0). April 2000.

- 2000c. Accelerating Cleanup: Paths to Closure. DOE/NV-586. January 2000.

- 2000d. Corrective Action Plan for Corrective Action Unit 417: Central Nevada Test Area, Nevada. DOE/NV--588. Environmental Restoration. April 2000.

— 1999a. Format and Content Guide for U.S. Department of Energy Low-Level Waste Disposal Facility Closure Plans. Unpublished DOE guidance. November 10, 1999.

- 1999b. Maintenance Guide for U.S. Department of Energy Low-Level Waste Disposal Facility Performance Assessments and Composite Analyses. DOE G 435.1-3. U.S. Department of Energy, Washington, D.C. November 10, 1999. 1999c. 200-BP-1 Prototype Barrier Treatability Test Report. DOE/RL-99-11, Rev. 0. August 1999.

— , 1997. "Regional Groundwater Flow and Tritium Transport Modeling and Risk Assessment of the Underground Test Area, Nevada Test Site, Nevada," DOE/NV-477, Las Vegas, NV.

- 1996. Final Environmental Impact Statement for the Nevada Test Site and Off-Site Locations in the State of Nevada. DOE/EIS-0243. Nevada Operations Office, Las Vegas, Nevada.

- 1991. Environmental Regulatory Guide for Radiological Effluent Monitoring and Environmental Surveillance. DOE/EH-0173T. January 1991.

DOE Order 435.1, "Radioactive Waste Management.” U.S. Department of Energy, Washington, D.C., August 28, 2001. 
DOE G 435.1-1, “General Responsibilities and Requirements.” U.S. Department of Energy, Washington, D.C., July 9, 1999.

DOE M 435.1-1, "Radioactive Waste Management Manual.” U.S. Department of Energy, Washington, D.C., June 19, 2001.

DOE Order 450.1, “Environmental Protection Program," U.S. Department of Energy, Washington, D.C., January 15, 2003.

5400.5, Chg. 2. "Radiation Protection of the Public and the Environment." U.S. Department of Energy, Washington, D.C., January 7, 1993.

Doorenbos, J., and W. O. Pruitt, 1977. Guidelines for Predicting Crop Water Requirements. FAO Irrigation and Drainage Paper No. 24, 2nd ed., FAO Rome, Italy. 156 pp.

Drellack, S. L., Jr., 1994. “An Introduction to NTS Geology and Geophysical Log Characteristics." Raytheon Services Nevada. May 1994.

Drellack, S. L., and P. H. Thompson, 1990. Selected Stratigraphic Data for Drillholes in LANL Use Areas of Yucca Flat. DOE/NV/10322-39. U.S. Department of Energy Report.

Dwyer, S. F., 2001. “Finding a Better Cover.” Civil Engineering. January 2001, pp. 58-63.

Dwyer, S. F., 1998. "Alternative Landfill Covers Pass the Test." Am. Soc. Civil Engineers. Civil Engineering, September 1998.

Elletson, L. W., and K. R. Johnejack, 1995. Waste Inventory Report for the U-3ax/bl Disposal Unit at the NTS. DOE/NV/11432-193. REECo, December 1995.

EPA (U.S. Environmental Protection Agency), 1994. "Guidance for the Data Quality Objectives Process.” EPA A/G-4. Quality Assurance Management Staff, Washington, D.C.

FFACO (Federal Facilities Agreement and Consent Order), 1996. Prepared by the Nevada Division of Environmental Protection, the U.S. Department of Energy, and the U.S. Department of Defense.

French, R. H., and S. Curtis, 1999. The Precipitation Event of 23-24 February 1998; Analysis of a Design-Level Event. DOE/NV/11508--48. Desert Research Institute Publication 45170, September 1999.

Frizzell, J. A., Jr., and J. Shulters, 1990. Geologic map of the Nevada Test Site, southern Nevada. U.S. Geological Survey Miscellaneous Investigations Series Map I-2046, scale $1: 100,000$. 
Garside, L. J., R. H. Hess, K. L. Fleming, and B. S. Weider, 1988. “Oil and Gas Developments in Nevada." Nevada Bureau of Mines and Geology Bulletin 104, Reno, Nevada.

Goering, T., 1999. "Use of a Close-Coupled Landfill Cover and Vadose Zone Monitoring System to Reduce Long-Term Groundwater Monitoring Costs." 11th Technical Information Exchange Conference, October 26-28, 1999, Las Vegas, Nevada.

Gonzales J. L., S. L. Drellack, S.L., and M. T. Townsend, 1998. Descriptive narrative for the Hydrogeologic Model at the Yucca Flat Corrective Area Unit. An interim report. Bechtel Nevada, Las Vegas, Nevada.

Gonzales J. L. and S. L. Drellack, 1999. "Addendum to the Descriptive Narrative for the Hydrogeologic Model of the Yucca Flat Corrective Area Unit: Northern Extension," Bechtel Nevada, Las Vegas, Nevada.

Grauch, V. J. S., and M. R. Hudson. 1995. Preliminary Analysis of Major Structures and Lithologic Boundaries for the Frenchman Flat Model Area. Denver, CO: U.S. Geological Survey.

Gustafson, D. L., S. E. Rawlinson, and J. J. Miller, 1993. "Summary of Natural Resources That Potentially Influence Human Intrusion at the Area 5 RWMS, DOE/NTS, Nye County, Nevada." Raytheon Services Nevada. August 1993.

Hale, G. S., D. A. Trudeau and C. S. Savard. 1995. "Water-Level Data from Wells and Test Holes Through 1991, and Potentiometric Contours as of 1991 for Yucca Flat, Nevada Test Site, Nye County, Nevada", Water-Resources Investigations report 95-4177, U.S. Geological Survey, Denver, CO.

Hankonson, T. E., L. J. Lane, and E. P. Springer, 1992. "Biotic and Biotic Processes." In: Reich, C. C., and B. M. Thomson (eds)., Deserts as Dumps? The Disposal of Hazardous Materials in Arid Ecosystems. University of New Mexico Press, Albuquerque, New Mexico.

Hannon, R. M., and H. L. McKague, 1975. An Examination of the Geology and Seismology Associated with Area 410 at the Nevada Test Site. UCRL-51830. Lawrence Livermore National Laboratory, Livermore, California.

Hansen, D. J., and W. K. Ostler, 2003. Rooting Characteristics of Vegetation Near Areas 3 and 5 Radioactive Waste Management Sites at the Nevada Test Site. DOE/NV/11718--595. Report to National Nuclear Security Administration Nevada Site Office, Las Vegas, Nevada. September 2003.

Hunter, R. B., 1992. Status of the Flora and Fauna on the Nevada Test Site, 1989-1991. Unpublished manuscript. 
IT Corporation. 1998. Underground Test Area Subproject, Corrective Action Unit 98:

Frenchman Flat Data Analysis Task, Volume I-Hydrostratigraphic Model

Documentation Package, Draft. ITLV/13052-044.

— 1996a. Groundwater Flow Model Documentation Package (Phase I Data Analysis Documentation, Volume VI). Prepared for DOE/NV. Las Vegas, NV.

— 1996b. Hydrologic Parameters Data Documentation Package (Phase I Data Analysis Documentation, Volume IV). ITLV/10972-181. Las Vegas, NV.

Kearl, P. M., 1982. "Water Transport in Desert Alluvial Soil.” Desert Research Institute, Bioresources Center Publication 45024.

Knauss, K. G., 1981. Dating Fault Associated Quaternary Material from the Nevada Test Site Using Uranium-series Method. UCRL-53231. Lawrence Livermore National Laboratory Report, $51 \mathrm{p}$.

Laczniak, R. J., J. C. Cole, D. A. Sawyer, and D. A. Trudeau, 1996. Summary of Hydrogeologic Controls on Ground-Water Flow at the Nevada Test Site, Nye County, Nevada. USGS. Water-Resources Investigations Report 96-4109.

Levitt, D. G., and T. M. Fitzmaurice, 2001. "Deployment of an Alternative Closure Cover and Monitoring System at the Mixed Waste Disposal Unit U-3ax/bl at the Nevada Test Site." Proceedings of the Waste Management '01 Conference, Tucson, Arizona.

Levitt, D. G., M. J. Sully, B. L. Dozier and C. F. Lohrstorfer, 1999. "Determining the Performance of an Arid Zone Radioactive Waste Site Through Site Characterization, Modeling and Monitoring." Proceedings of the Waste Management '99 Conference, Tucson, Arizona.

Levitt, D. G., B. L. Dozier, J. M. Dixon and L. T. Desotell, 1998. "The Influence of Climate and Vegetation as Factors for Waste Cover Design." Proceedings of the DOE Nevada Vadose Zone Monitoring Workshop, September 24-25, 1998, Las Vegas, Nevada.

Levitt, D. G., C. F. Lohrstorfer, M. J. Sully, and J. M. Ginanni, 1996. "An Arid Zone Lysimeter Facility for Performance Assessment and Closure Investigations at the Nevada Test Site." Proceedings of Waste Management'96 Conference, Tucson, Arizona.

Magnuson, S. O., S. J. Maheras, H. D. Nguyen, A. S. Rood, J. I. Sipos, M. J. Case, M. A. McKenzie-Carter, and M. E. Donahue, 1992. Radiological Performance Assessment for the Area 5 Radioactive Waste Management Site at the Nevada Test Site, Revision 1. Idaho National Engineering Laboratory, Idaho Falls, Idaho. 
Metcalf, L. A., 1983. "A Preliminary Review and Summary of the Potential for Tectonic, Seismic, and Volcanic Activity at the Nevada Test Site Defense Waste Disposal Site." Desert Research Institute, Water Resources Center Publication 45029. DOE Report DOE/NV/01162-7.

Miller, J. J. ,1996. Flood Assessment for the Area 3 Radioactive Waste Management Site, Nevada Test Site, Nye County, Nevada. Bechtel Nevada report to U.S. Department of Energy, Nevada Operations Office.

NAC (Nevada Administrative Code). NAC 444.743, "Final Cover or Closure; Postclosure." September 2, 1992; amended November 8, 1993.

- NAC 444.6891, "Requirements for Design and Construction of System for Final Cover." November 8, 1993.

NDEP (Nevada Division of Environmental Protection), November 2000. Permit for a Hazardous Waste Facility, Permit No. NEV HW009.

NEC (Nevada Environmental Commission), 1987. "Nevada Administrative Code (NAC) 444.8632 - Compliance with Federal Regulations Adopted by Reference.” July 22, 1987 as amended.

Neptune \& Co., 2004. Letter Report Area 5 GoldSim Model Version 3.0, Paul Black, Neptune and Company letter to Jhon Carilli, National Nuclear Security Administration Nevada Site Office, June 30, 2004.

NNSA/NSO (National Nuclear Security Administration Nevada Site Office), 2003. Nevada Test Site Waste Acceptance Criteria. DOE/NV-325, Rev. 5. December 2003.

NNSA/NV, (National Nuclear Security Administration Nevada Operations Office), 2001. Closure Report for Corrective Action Unit 110: Area 3 RWMS U-3ax/bl Disposal Unit, Nevada Test Site, Nevada. DOE/NV--733. Environmental Restoration Division. June 2001.

Obi, C. M., G. J. Shott, C. J. Muller, and L. E. Barker, 1996. Preliminary Estimates of Future Waste Subsidence, Hydrogeologic Impact, and Contaminant Concentrations for Area 3 RWMS Disposal Units at the NTS. Bechtel Nevada. October 1996.

O'Farrell, T. P., and L.A. Emery, 1976. Ecology of the Nevada Test Site: A Narrative Summary and Annotated Bibliography. NVO-167. National Technical Information Service Publication, Springfield, Virginia.

O'Farrell, T. P., and R. O. Gilbert, 1975. “Transport of Radioactive Materials by Jackrabbits on the Hanford Reservation." Health Physics, Vol. 29, p. 9-15. 
Orkild, P. P., 1983. "Geology of Nevada Test Site.” In: B. C. Hudson, E. M. Jones, C. E. Keller, and C. W. Smith (eds.), Proceedings of the Monterey Containment Symposium, Monterey, California, August 26-28, 1981. LA-9211-C, v.1, p. 323-338. Los Alamos National Laboratory Report.

Ostler, W. K., D. J. Hansen, D. C. Anderson, and D. B. Hall, 2000. Classification of Vegetation on the Nevada Test Site. DOE/NV/11718--477. Report to the U.S. Department of Energy, Nevada Operations Office, Las Vegas, Nevada. December 2000.

REECo (Reynolds Electrical \& Engineering Co., Inc.), 1994. Site Characterization and Monitoring Data from Area 5 Pilot Wells, NTS, Nye County, Nevada. DOE/NV/11432-74. February 1994.

1993a. Hydrogeologic Data for Existing Excavations at the Area 5 RWMS, NTS, Nye County, Nevada. DOE/NV/11432-40. December 1993.

1993b. Hydrogeologic Data for Science Trench Boreholes at the Area 5 RWMS, NTS, Nye County, Nevada. December 1993.

1980. Nevada Test Site Radioactive Waste Management Consolidation Report. Waste Management Department, Reynolds Electrical \& Engineering Co., Inc., Las Vegas, Nevada.

1968. Nevada Test Site waste disposal records. Waste Management Department, Reynolds Electrical \& Engineering Company, Inc., Las Vegas, Nevada.

Reno, R. L., and L.C. Pippin, 1985. “An Archeological Reconnaissance of Yucca Flat, Nye County, Nevada.” Desert Research Institute Technical Report No. 35, Las Vegas, Nevada.

Richard-Haggard, K., 1983. Economic Potential of Alternative Land and Natural Resources Uses at the Nevada Test Site, Nye County, NV. Desert Research Institute Publication No. 45030, Las Vegas, Nevada.

Rogers, A. M., D. M. Perkins, and F. A. McKeon, 1977. A Preliminary Assessment of the Seismic Hazard of the Nevada Test Site Region. Bulletin of the Seismology Society of America, Vol. 67, p. 1587-1606.

SAIC/DRI (Science Applications International Corporation/Desert Research Institute), 1991. Special Nevada Report, U.S. Air Force, Tactical Weapons Center, Office of Public Affairs, Nellis Air Force Base, Las Vegas, Nevada.

Schmeltzer, J. S., L. E. Barker, and D. O. Blout, 1996. Site Characterization Data from the U-3ax/bl Exploratory Boreholes at the NTS. DOE/NV/11718-003. Bechtel Nevada. April 1996. 
Schmeltzer, J. S., J. J. Miller, and D. L. Gustafson, 1993. "Flood Assessment at the Area 5 Radioactive Waste Management Site and the Proposed Hazardous Waste Storage Unit, DOE, Nevada Test Site, Nye County, Nevada." Raytheon Services Nevada.

Shott, G. J., L. E. Barker, S. E. Rawlinson, M. J. Sully, and B. A. Moore, 1998. Performance Assessment of the Area 5 RWMS at the NTS, Nye County, Nevada. Revision 2.1. DOE/NV/11718--176. Bechtel Nevada. January 1998.

Shott, G. J., V. Yucel, M. J. Sully, L. E. Barker, S. E. Rawlinson, and B. A. Moore, 1997. Performance Assessment/Composite Analysis for the Area 3 RWMS at the NTS, Nye County, Nevada. Revision 2.0. DOE/NV--491. Bechtel Nevada. September 1997.

Shott, G. J., C. J. Muller, L. E. Barker, D. E. Cawlfield, F. T. Lindstrom, D. G. Linkenheil, M. J. Sully, L. McDowell-Boyer, and D. J. Thorne, 1995. Performance Assessment for the Area 5 Radioactive Waste Management Site at the Nevada Test Site, Nye County, Nevada. Rev. 2.0. DOE/NV/11432--196. June 1995.

Snyder, K. E, D. L. Gustafson, J. J. Miller, S. E. Rawlinson, 1994. Geological Components of Site Characterization and Performance Assessment for a Radioactive Waste Management Facility at the Nevada Test Site. DOE/NV/10833-20. Waste Management 1994, Tucson, Arizona.

Trexler, J. H., J. C. Cole, and P. H. Cashman, 1996. "Middle Devonian-Mississippian Stratigraphy on and near the Nevada Test Site: Implications for Hydrocarbon Potential." American Association of Petroleum Geologists Bulletin, Vol. 80, p. 1736-1762.

Tyler, S. W., J. B. Chapman, S. H. Conrad, D. P. Hammermeister, D. O. Blout, J. J. Miller, M. J. Sully, and J. M Ginanni, 1996. "Soil-Water Flux in the Southern Great Basin, United States: Temporal and Spatial Variations over the Last 120,000 Years." Water Resources Research 32(6):1481-1499.

Walker, G. E., 1962. "Groundwater in the Climax Stock, Nevada Test Site, Nye County, Nevada,” U.S. Geological Survey Trace Element Investigations Report TEI-813, 48pp., Washington, DC.

Wallace, A., E. M. Romney, and R. B. Hunter, 1980. "The Challenge of a Desert: Revegetation of Disturbed Desert Lands." In: Great Basin Naturalist Memoirs. No. 4. Brigham Young University.

Wallace, A., and E. M. Romney, 1972. Radioecology and Ecophysiology of Desert Plants at the Nevada Test Site. National Technical Information Service Publication TID-25954, Springfield, Virginia. 
Wills, C. A. and W. K. Ostler, 2001. Ecology of the Nevada Test Site: An Annotated Bibliography, With Narrative Summary, Keyword Index, and Species List. DOE/NV/11718-594. December 2001.

Winograd, I. J., and W. Thordarson, 1975. "Hydrogeologic and Hydrochemical Framework, South-Central Great Basin, Nevada-California, with Special Reference to the Nevada Test Site." Hydrology of Nuclear Test Sites. U.S. Geological Survey Professional Paper 712-C.

Winkel, V. K., J. P. Angerer, D. B. Hall, M. W. Fariss, and K. R. Johnejack, 1995. Plant and Burrowing Animal Characteristics. Integrated Closure Program for the Area 3 and Area 5 RWMSs, NTS. EG\&G and REECo, March 1995.

Wirth, S., T. Brown, and W. Beyler, 1999. Native Plant Uptake Model for Radioactive Waste Disposal Areas at the Nevada Test Site. SAND98-1789. Sandia National Laboratories Report.

Young, M. H., P. J. Wierenga, A. W. Warrick, L. L. Hofmann, S. A. Musil, M. Yao, C. J. Mai, Z. Zou, and B. R. Scanlon, 1999. Results of Field Studies at the Maricopa Environmental Monitoring Site, Arizona. NUREG/CR-5694. U.S. Nuclear Regulatory Commission, June 1999. 


\section{APPENDIX A}

\section{CROSS-WALK BETWEEN CLOSURE PLAN GUIDANCE AND THE INTEGRATED CLOSURE AND MONITORING PLAN}

The outline below is based on the U.S. Department of Energy (DOE) Format and Content Guide for U.S. Department of Energy Low-Level Waste Disposal Facility Closure Plans, dated November 10, 1999. Because this Integrated Closure and Monitoring Plan is a reference document and includes both closure and monitoring activities, the format does not conform exactly with the DOE guidance. Referenced sections are those in this Integrated Closure and Monitoring Plan that most closely correspond to guidance outline. The format and contents of the Integrated Closure and Monitoring Plan follow this information.

\section{Guidance}

EXECUTIVE SUMMARY

INTRODUCTION

Facility Description

Closure and Monitoring Approach

Closure and Monitoring Schedule

Related Activities

Assumptions

DISPOSAL FACILITY CHARACTERISTICS

Site Characteristics

Geography and Demography

Disposal Site Location

Disposal Site Description

Population Distribution

Uses of Adjacent Land

Meteorology and Climatology

Ecology

Geology

Regional and Site-Specific

Geology/Topography

Hydrology Seismology

Surface Water

Groundwater

Geochemistry

Natural Resources
Corresponding Section(s)

Executive Summary

1.0

4.0, 4.1, 4.2, 4.3, 5.0, 5.1, 5.2,

5.3

$1.4,1.4 .1,1.4 .2,7.0,9.0$

1.8

$1.10,5.5$

1.5

$3.0,4.0,5.0$

$3.1,3.2$

$4.1,5.1$

$4.1,4.2,4.3,5.1,5.2,5.3$

3.2.1

3.2 .2

3.3

3.4

3.5

3.5.1, 3.5.2, 3.5.3

3.8 .1

3.6

3.6.1

3.6.2, 3.6.3, 3.6.4

3.7

3.9 


$\begin{array}{cl}\text { Facility Characteristics } & 6.0,6.1,6.2 \\ \text { Water Infiltration } & 6.2 .3 \\ \text { Disposal Unit Cover Integrity } & 6.2 .6 \\ \text { Structural Stability } & 6.2 .6 \\ \text { Inadvertent Intruder Barrier } & 6.2 .5 \\ \text { Waste Characteristics } & 4.4,5.4 \\ \text { Waste Types } & 4.4 .3,5.4 .3 \\ \text { Source Term } & 4.4 .3,5.4 .3 \\ \text { TECHNICAL APPROACH TO CLOSURE AND MONITORING } \\ \text { Performance Objectives } & 4.5,5.5 \\ \text { All-Pathways Dose } & 4.5 .1,5.5 .1 \\ \text { Air-Pathway Dose } & 4.5 .1,5.5 .1 \\ \text { Radon Flux } & 4.5 .1,5.5 .1 \\ \text { Other Requirements } & 4.5 .3 \\ \text { Operational/Interim Closure } & 7.0 \\ \text { Final Closure } & 7.1 \\ \text { Institutional Control } & 7.2 \\ \text { Unrestricted Release of Site } & 8.1 \\ \text { Detailed Closure Activities } & 8.1 .3 \\ \text { Operational/Interim Closure } & 9.0 \\ \text { Final Closure/Institutional Care } & 9.4 \\ \text { SCHEDULE } & 9.14,9.15 \\ \text { REFERENCES } & 1.8 \\ \text { APPENDICES } & 10.0 \\ & \mathrm{Appendix} \mathrm{A}\end{array}$

This outline is provided to show that more sections are in the Plan than are specified in the guidance. It serves as a quick reference so the reader does not have to go to the Table of Contents to find the Section Titles when reading the previous few pages. 


\section{DISTRIBUTION LIST}

\section{U.S. Department of Energy}

Jhon Carilli

2 (uncontrolled)

Waste Management Division

U.S. Department of Energy

National Nuclear Security Administration

Nevada Site Office

P.O. Box 98518, M/S 505

Las Vegas, NV 89193-8518

E. Frank Di Sanza

1 (uncontrolled)

Waste Management Division

U.S. Department of Energy

National Nuclear Security Administration

Nevada Site Office

P.O. Box 98518, M/S 505

Las Vegas, NV 89193-8518

B.M. Crowe

1 (uncontrolled)

Apogen Technologies

U.S. Department of Energy

National Nuclear Security Administration

Nevada Site Office

P.O. Box 98518, M/S 505

Las Vegas, NV 89193-8518

Sabine Curtis

Environmental Restoration Division

1 (uncontrolled)

U.S. Department of Energy

National Nuclear Security Administration

Nevada Site Office

P.O. Box 98518, M/S 505

Las Vegas, NV 89193-8518

Michael Giblin

1 (uncontrolled)

Waste Management Division

U.S. Department of Energy

National Nuclear Security Administration

Nevada Site Office

P.O. Box 98518, M/S 505

Las Vegas, NV 89193-8518 


\section{DISTRIBUTION LIST (Continued)}

U.S. Department of Energy

1 (uncontrolled)

National Nuclear Security Administration

Nevada Site Office

Technical Library

P.O. Box 98518, M/S 505

Las Vegas, NV 89193-8518

U.S. Department of Energy

1 (uncontrolled)

National Nuclear Security Administration

Nevada Site Office

Public Reading Facility

c/o Nuclear Testing Archive

P.O. Box 98521, M/S 400

Las Vegas, NV 89193-8521

U.S. Department of Energy

Office of Scientific and Technical Information

1 (electronic,

Post Office Box 62

uncontrolled)

Oak Ridge, Tennessee 37831-0062

\section{Bechtel Nevada}

Eric Amarescu

1 (uncontrolled)

Bechtel Nevada

P.O Box 98521, M/S NTS305

Las Vegas, NV 89193-8521

Max Dolenc

1 (uncontrolled)

Bechtel Nevada

P.O Box 98521, M/S NSF083

Las Vegas, NV 89193-8521

David Hudson

1 (uncontrolled)

Bechtel Nevada

P.O Box 98521, M/S NTS273

Las Vegas, NV 89193-8521

Renee Hudson

1 (uncontrolled)

Environmental Management Library

1 (electronic,

Bechtel Nevada

P.O Box 98521, M/S NLV094

uncontrolled)

Las Vegas, NV 89193-8521 


\section{DISTRIBUTION LIST (Continued)}

Steve Nacht

1 (uncontrolled)

Bechtel Nevada

P.O Box 98521, M/S NSF083

Las Vegas, NV 89193-8521

Terry Ploeger

1 (uncontrolled)

Bechtel Nevada

P.O Box 98521, M/S NTS403

Las Vegas, NV 89193-8521

Carlos Ramirez

1 (uncontrolled)

Bechtel Nevada

P.O Box 98521, M/S NSF083

Las Vegas, NV 89193-8521

Saligrama Rao

1 (uncontrolled)

Bechtel Nevada

P.O Box 98521, M/S NSF022

Las Vegas, NV 89193-8521

Stuart Rawlinson

1 (uncontrolled)

Bechtel Nevada

P.O Box 98521, M/S NTS416

Las Vegas, NV 89193-8521

Greg Shott

Bechtel Nevada

P.O Box 98521, M/S NSF081

Las Vegas, NV 89193-8521

Carl Soong

Bechtel Nevada

P.O Box 98521, M/S NTS327

Las Vegas, NV 89193-8521

Dan Tobiason

1 (uncontrolled)

Bechtel Nevada

P.O Box 98521, M/S NTS416

Las Vegas, NV 89193-8521

1 (uncontrolled)

1 (uncontrolled) 


\section{DISTRIBUTION LIST (Continued)}

Don Van Etten

1 (uncontrolled)

Bechtel Nevada

P.O Box 98521, M/S NTS273

Las Vegas, NV 89193-8521

Vefa Yucel

1 (uncontrolled)

Bechtel Nevada

P.O Box 98521, M/S NSF081

Las Vegas, NV 89193-8521 